\title{
Involvement of protein cofactors in the expression of antiphospholipid antibodies
}

Citation for published version (APA):

Galli, M. M. T. (1993). Involvement of protein cofactors in the expression of antiphospholipid antibodies. [Doctoral Thesis, Maastricht University]. Rijksuniversiteit Limburg. https://doi.org/10.26481/dis.19930506mg

Document status and date:

Published: 01/01/1993

DOI:

10.26481/dis.19930506mg

Document Version:

Publisher's PDF, also known as Version of record

\section{Please check the document version of this publication:}

- A submitted manuscript is the version of the article upon submission and before peer-review. There can be important differences between the submitted version and the official published version of record.

People interested in the research are advised to contact the author for the final version of the publication, or visit the DOI to the publisher's website.

- The final author version and the galley proof are versions of the publication after peer review.

- The final published version features the final layout of the paper including the volume, issue and page numbers.

Link to publication

\footnotetext{
General rights rights.

- You may freely distribute the URL identifying the publication in the public portal. please follow below link for the End User Agreement:

www.umlib.nl/taverne-license

Take down policy

If you believe that this document breaches copyright please contact us at:

repository@maastrichtuniversity.nl

providing details and we will investigate your claim.
}

Copyright and moral rights for the publications made accessible in the public portal are retained by the authors and/or other copyright owners and it is a condition of accessing publications that users recognise and abide by the legal requirements associated with these

- Users may download and print one copy of any publication from the public portal for the purpose of private study or research.

- You may not further distribute the material or use it for any profit-making activity or commercial gain

If the publication is distributed under the terms of Article $25 \mathrm{fa}$ of the Dutch Copyright Act, indicated by the "Taverne" license above, 
Involvement of Protein Cofactors in the Expression of Antiphospholipid Antibodies

Monica Galli 



\section{Involvement of Protein Cofactors in the Expression of Antiphospholipid Antibodies}

\section{PROEFSCHRIFT}

ter verkrijging van de graad van doctor

aan de Rijksuniversiteit Limburg te Maastricht, op gezag van de Rector Magnificus, Prof. Mr. M.J. Cohen, volgens het besluit van het College van Dekanen, in het openbaar te verdedigen op donderdag, 6 mei 1993 om 14.00 uur

door

Monica Maria Teresa Galli 


\section{Promotor:}

Prof. Dr. R.F.A. Zwaal

Co-promotor:

Dr. E.M. Bevers

Beoordelingscommissie:

Prof. Dr. P.J.C. van Breda Vriesman (voorzitter)

Prof. Dr. P.J. Brombacher

Prof. Dr. M.C.E. van Dam-Mieras (Open Universiteit)

Prof. Dr. P. de Leeuw

Prof. Dr. J. Vermylen (Katholieke Universiteit Leuven)

Financial support by 'Het Nationaal Reumafonds' (grant 91/CR/329) and by the European Community (grant EC 87-0225 I 4) is gratefully acknowledged. 
"Tanto lo scienziato che 1' artista vivono sempre al margine del mistero che li circonda; entrambi, a seconda della portata del loro atto creativo, si sono sempre occupati di armonizzare ciò che è nuovo con quello che è noto, di mantenere l' equilibrio tra novità e sintesi, di lottare per addivenire ad un ordine parziale nell' ambito del caos totale". R. Oppenheimer, da "Le Parole in Medicina", Il Pensiero Scientifico Editore, 1988 , pag. 8 


\section{CONTENT}

\section{Chapter I:}

Introduction

Chapter II:

Lupus Anticoagulant IgG's (LA) are not directed to phospholipids only, but to a complex of lipid-bound human prothrombin based on: Thromb Haemostas 1991; 66: 629-32

Chapter III:

Anticardiolipin antibodies (aCL) directed not to cardiolipin but to a plasma protein cofactor. Lancet 1990; 335: 1544-47.

Appendix:

$B_{2}$-Glycoprotein I for binding of anticardiolipin antibodies to cardiolipin. Lancet 1990; 336: 952-53

Chapter IV:

Anticoagulant activity of $B_{2}$-Glycoprotein $I$ is potentiated by a distinct subgroup of anticardiolipin antibodies

Thromb Haemostas 1992; 68: 297-300 page 59

Chapter V:

Effect of antiphospholipid antibodies on procoagulant activity of activated platelets and platelet-derived microvesicles

Br J Haematol 1993; in press. page 73

Chapter VI:

General discussion page 89

Chapter VII:

Summary and conclusions page 101

Sommario e conclusioni page 105

Samenvattings en conclusies page 109

List of publications page 113

Aknowledgements page 115

Curriculum vitae 



\section{CHAPTER I}

\section{INTRODUCTION}

\section{HISTORICAL BACKGROUND}

\section{Antibodies directed against lipids}

At the beginning of this century proteins were the only molecules believed to be immunogenic. This concept was based mainly on the work of the great immunologist Paul Ehrlich. In contrast, lipids were considered to be poor antigens or even non-immunogenic, because of their small size. This idea was derived originally from the studies of Karl Landsteiner, who observed that "...When the usual methods of immunization were used, specific proteinfree substances of animal or bacterial origin, although active 'in vitro', often induced no or only a slight antibody response." (1). He also observed that upon mixing with heterologous serum, lipids could stimulate an immune response in the injected animal. Based on these findings, Landsteiner developed the theory of the "hapten" for low molecular weight molecules, which could induce an immune response only after their attachment to high molecular weight carriers (such as proteins or cells) (1).

This concept was challenged in 1925 by Sachs and Klopstock, who describer a method for the production of antibodies to lecithin (phosphatidylcholinc) and cholesterol (2). Over the next decades these findings have been confirmed and extended by other authors (3). Nowadays the principle that lipids are immunogenic is widely accepted and has several practical implications, such as the development of assays for the measurement of steroids, eicosanoids and "lipid-like" drugs and the recognition of naturally occurring autoantibodics against different kinds of lipid molecules. 


\section{Antibodies directed against phospholipids}

The development by Wasserman in 1906 of a complement fixation test to detect "reagin" in the serum of patients suffering from syphilis represents the beginning of the history of antiphospholipid antibodies (4). It was at first believed that "reagin" was an antibody directed against the treponema (or one of its specific antigenic determinants) present in the saline extracts of liver from fetuses with congenital syphilis. However, in the subsequent years it became clear that the antigen in the reaction could be replaced by alcoholic extracts of several normal tissues as well. In 1941 Pangborn demonstrated that "reagin" was directed against the anionic (read: negatively-charged) phospholipid extracted from bovine heart (5). This phospholipid has been named cardiolipin.

At the beginning of the 1950s an important observation was made by More and Mohr (6), who reported the existence of patients who had detectable "reagin" in their serum without ever suffering from syphilis. This biologic false positive test was commonly found in two groups of diseases: viral and bacterial infections and autoimmune disorders (particularly Systemic Lupus Erythematosus, SLE). In the former case the biologic false positive test for syphilis was typically transient, whereas it was chronic in the latter group of conditions.

In the same period a new inhibitor of coagulation was described. In 1951 Mueller et al. (7) and in 1952 Conley and Hartman (8) reported 3 cases of a peculiar circulating acquired anticoagulant which prolonged the whole blood coagulation time and the prothrombin time, was not neutralized upon addition of normal plasma to the plasma of the patients and was associated with a chronic false positive test for syphilis. Moreover, in one case the anticoagulant activity was described to be dependent on the concentration of the thromboplastin and clinically associated with a history of thrombosis (7). The immunoglobulin nature of the inhibitor was suspected already in 1955, when it was observed that the anticoagulant was present both in a female patient and in her child during the first 6 months of life (9) and this idea was later confirmed by Loeliger in 1959 (10) and by Yin and Gaston in 1965 (11). Since the inhibitor was mostly detected in patients with SLE, it was named 
Lupus Anticoagulant (LA) (12). LA antibodies, however, have been detected in a number of pathologic conditions, such as autoimmune disorders other than SLE, malignancies, infections, in association with several drugs and also in the absence of an underlying disease (13). The strong association between LA antibodies and the false positive test for syphilis was first recognized in 1957, when Laurell and Nilsson (14) observed that LA activity could be adsorbed from plasma by the cardiolipin portion of the Kahn antigen used in syphilis tests.

\section{Laboratory tests for the identification of antiphospholipid antibodies}

The identification of LA antibodies in plasma is based on the prolongation of the coagulation time of a variety of phospholipid-dependent coagulation tests, such as the kaolin clotting time (15), the activated partial thromboplastin time, the tissue thromboplastin inhibition test (13) and/or the dilute Russell viper venom time (16). To exclude that the prolongation of the clotting time is caused by a deficiency of one or more coagulation factors, it should be ensured that the prolongation cannot be neutralized upon mixing of normal plasma with the test plasma. It is also necessary to rule out that the inhibitor is directed against any coagulation factor. Moreover, a relative correction of the inhibitory effect should be achieved by addition of lysed platelets or liposomes containing phosphatidylserine or hexagonal phase $\left(\mathrm{H}_{\mathrm{II}}\right)$ phospholipids (see below) (17). These criteria are based on the indications given by an International Workshop in 1983 (18), which have been recently revised (19). However, no conclusive agreement has yet been reached on the methodology for the diagnosis of LA antibodies, illustrated by the great number of different coagulation tests which have been proposed over the last decade (20-27).

In 1983, the development of a sensitive solid phase radioimmunoassay (RIA) for the measurement of anticardiolipin (aCL) antibodies replaced the semi-quantitative assays which detected "reagin" in serum (28). Two years later an enzyme-linked immunosorbent assay (ELISA) was proposed for aCL antibodies, which was shown to be as sensitive as the RIA (29). At variance with most immunoassays, it was observed that $10 \%$ bovine serum solution was 
necessary throughout the ELISA for aCL antibodies, in order to obtain the best bindings with the lowest background (30).

Soon after the report of this method, it became evident that cardiolipin could be replaced in the ELISA by other negatively-charged phospholipids as well, such as phosphatidylserine, phosphatidic acid or phosphatidylinositol (31-33). On the basis of this finding, assays have been developed that are based on the adsorption on the ELISA plates of a mixture of negativelycharged phospholipids. However, the higher specificity and sensitivity of these assays over the tests in which a single anionic phospholipid is used as an antigen remain to be demonstrated. In this respect, two International Workshops have been organized in recent years to standardize the measurement of aCL antibodies $(34,35)$. In spite of all these efforts, no general agreement on the methodology for the detection of $\mathrm{aCL}$ antibodies has yet been achieved and more work will be necessary in the future.

\section{Clinical associations of antiphospholipid antibodies}

As mentioned above, the association between LA antibodies and thrombosis was already described in 1951 in the first patient with antiphospholipid antibodies (7). However, it was not until 1963 that the association of LA antibodies with thromboembolic complications was clearly recognized (36). Over the next decades several reports of large series of patients confirmed the association between antiphospholipid antibodies and a history of thrombosis of both venous and arterial vessels (37). Association was found also between the presence of antiphospholipid antibodies and a history of early recurrent abortions, intra-uterine deaths and intra-uterine growth retardation (38). In these cases thrombosis of the placental vessels has been considered the cause of the poor pregnancy outcome (39). Recently, epidemiological case-control studies performed by our group established the risk of thrombosis in antiphospholipid antibody-positive patients $(40,41)$.

Antiphospholipid antibodies are significantly associated also with mild thrombocytopenia, particularly in patients with SLE (42). Less frequently, also thrombocytopathia has been described (43). So far, severe thrombocytopenia, thrombocytopathia and/or hypoprothrombinemia are the 
only known conditions in which antiphospholipid antibody-positive patients may be at risk of bleeding complications (44).

The association between antiphospholipid antibodies and thrombosis, recurrent abortions and thrombocytopenia defines a syndrome, named the "Antiphospholipid Syndrome" (45), which can occur within SLE or as a separate clinical condition, the so-called "Primary Antiphospholipid Syndrome" (46). Also livedo reticularis and haemolytic anaemia have been frequently reported in the Antiphospholipid Syndrome (47).

\section{Role of antiphospholipid antibodies in the pathogenesis of thrombosis}

The association between antiphospholipid antibodies and thrombosis has stimulated a great deal of research aimed at defining a pathogenetic role of these antibodies in the development of thrombosis. Several hypotheses have been proposed, such as the reduction of the synthesis and/or the release of prostaclyclin by endothelial cells $(48,49)$, the interference with the thrombomodulin/protein C system (50-52), the stimulation of endothelial cell procoagulant activity (53-55), the activation of platelets (56), the inhibition of the fibrinolytic system (57), antithrombin III (58) and prekallikrein (59), the reduction of protein $S$ levels $(60)$ and the stimulation of the thrombin/ antithrombin complex formation (61).

Unfortunately, none of these hypotheses has been confirmed on large numbers of patients, so that the correlation between antiphospholipid antibodies and a history of thrombosis has not been unequivocally demonstrated. For this reason, the question whether these antibodies play any role in the development of thrombosis still remains to be clarified. In this respect, an answer to this crucial point might come from the animal models of antiphospholipid syndrome, which show that the development of antiphospholipid antibodies in mice is associated with clinical complications similar to those observed in humans. In particular, it has been described that the immunization of mice with aCL-positive serum (62), IgG containing antiphospholipid antibodies (63, 64) or monoclonal aCL antibodies (65) is followed by an increased resorption index of the fetuses (equivalent to recurrent abortions in humans). Similarly, NZW x BXSB Fl mice spontaneously develop systemic lupus-like disease, 
which is characterized by persistently elevated titer of aCL antibodies, thrombocytopenia and myocardial infarction (66). So far, these are the first substantial indications that aCL and/or LA antibodies might, actually, be involved in the pathogenesis of haemostatic complications.

\section{IMMUNOLOGICAL SPECIFICITY OF ANTIPHOSPHOLIPID ANTIBODIES}

\section{Anticardiolipin antibodies}

As already mentioned, the immunological specificity of "reagin" was elucidated in 1941 by Pangborn (5), who demonstrated that the antibody was directed against cardiolipin, the negatively-charged phospholipid present together with cholesterol and lecithin (phosphatidylcholine) in the VDRL (Venereal Disease Research Laboratory) antigen.

An important development in the field of the immunology of reagin was made by Cooper et al. (67), who purified from the serum of a patient suffering from chronic lymphocytic leukemia a monoclonal IgM, which expressed a very high VDRL titer and was able to precipitate both cardiolipin and phosphatidylcholine. Precipitin lines were observed also with phosphatidylserine, phosphatidic acid, phosphatidylethanolamine and sphingomyelin. For the first time the concept of the immunological crossreactivity of antiphospholipid antibodies was introduced. Interestingly, phosphatidylethanolamine, sphingomyelin and phosphatidylcholine are not negatively-charged but zwitterionic (read: neutral) phospholipids.

With the subsequent development of solid phase immunoassays $(28,29)$ it has been widely confirmed that aCL antibodies positive sera react with all the anionic phospholipids, whereas zwitterionic phospholipids are not recognized by aCL antibodies. There are, however, a few exceptions to this immunological behaviour, such as the observation of antiphosphatidylethanolamine antibodies reported by Staub et al. (68) and, as afore mentioned, Cooper et al. (67).

In some cases the wide immunological cross-reactivity of aCL 
antibodies has been extended to DNA, since some (monoclonal) anti-DNA antibodies were shown to bind also to cardiolipin $(31,69)$. This crossreactivity has been explained on the basis of the similarity between the polar head groups of the phospholipids and the phosphodiester groups on the polynucleotide backbone of DNA (31). However, in most cases anti-DNA and $\mathrm{aCL}$ antibodies comprise different specificities $(70,71)$.

\section{Lupus anticoagulant}

The hypothesis that LA might belong to the family of antiphospholipid antibodies originated from the frequent association with aCL (or "reagin") antibodies and from the prolongation of the phospholipid-dependent coagulation tests. However, it was not until 1980 that the antiphospholipid nature of LA antibodies was described, when a monoclonal IgM with LA activity was purified from the plasma of a patient suffering from Waldenström's macroglobulinemia (72). By double immunodiffusion the isolated $\operatorname{IgM}$ was shown to form a precipitin line with several negativelycharged phospholipids, such as phosphatidylserine, phosphatidic acid and phosphatidylinositol. Also its anticoagulant mechanism was elegantly elucidated: the $\operatorname{IgM}$ inhibited the calcium-dependent binding of coagulation factors $\mathrm{X}$ and prothrombin to the negatively-charged phospholipid procoagulant surface (72). The same group later confirmed and extended these findings to antibodies of the IgG isotype (73). They developed a method for the purification of aCL antibodies based on serum (or plasma) adsorption by liposomes containing cardiolipin and subsequent elution of the antibodies from the lipids. aCL antibodies isolated via this procedure were shown to bind not only to cardiolipin, but to a variety of negatively-charged phospholipids and to express LA activity as well, since they were able to prolong the coagulation time of phospholipid-dependent coagulation tests (73). Again, IgG aCL antibodies were shown to compete with coagulation factors $X$ and prothrombin for the calcium-dependent binding to the procoagulant phospholipid surface (73).

On the basis of these findings it was suggested that $\mathrm{LA}$ and $\mathrm{aCL}$ anibodies were closely related or even identical. The observation that these 
two antibodies were concurrently present in approximately $75 \%$ of the patients contributed to strengthen this hypothesis (42).

\section{$L A$ and $a C L$ antibodies comprise different immunological specificities}

In 1988 two groups of investigators independently reported that in most cases aCL could be separated from LA antibodies $(74,75)$. They used elegant methods for the purification of antiphospholipid antibodies, based on the immobilization of the anionic phospholipid (phosphatidylserine or cardiolipin) over columns of polyacrylamide gel (75) or polystyrene/ siliconized sand (74), respectively. The chromatography of LA and aCL antibodies positive plasmas over these columns resulted in the separation of the antibodies into two peaks, one containing LA, the other aCL antibodies. The evaluation of the immunological properties of the two separated antibodies showed that aCL antibodies were able to bind to several anionic phospholipids in the immunoassays but did not express anticoagulant activity in vitro, whereas LA antibodies, in spite of the ability to prolong the phospholipid-dependent coagulation reactions, did not bind to anionic phospholipids in the immunoassays (76). Moreover, in some patients aCL and LA antibodies belong to different immunoglobulin isotypes (76). Henceforth, the concept that $\mathrm{aCL}$ and $\mathrm{LA}$ antibodies comprise separate immunological specificities has been confirmed and widely accepted.

In the recent years the possibility that LA antibodies may be directed against unusual antigenic targets has been object of ample investigation. In this respect, it has been shown that the anticoagulant activity of LA antibodies can be neutralized in plasma by phosphatidylethanolamine, a neutral phospholipid, when it is used in the hexagonal $\left(\mathrm{H}_{\mathrm{II}}\right)$ phase (77). In contrast, the same lipid in the lamellar phase does not influence the expression of the anticoagulant activity of LA antibodies (77).

Most of the neutral and negatively-charged phospholipids commonly adopt the bilayer structure in aqueous solutions. However, it has been observed that phosphatidylethanolamine, as well as cardiolipin and phosphatidic acid, may also adopt hexagonal structures and non-bilayer intermediates under physiological conditions (78). 
Hexagonal $\left(\mathrm{H}_{\mathrm{II}}\right)$ phosphatidylethanolamine consists of hexagonally packed cylinders of lipid surrounding central aqueous channels toward which the polar head groups are oriented. In this way, a peculiar lipid surface is formed, that has been suggested to be specifically recognized by LA antibodies (79). In fact, human hybridoma LA IgM have been shown to distinguish between the lamellar and hexagonal $\left(\mathrm{H}_{\mathrm{II}}\right)$ phase of the same lipid (79). Although this is a very attractive hypothesis, there is still little evidence of direct binding of LA antibodies to hexagonal phase $\left(\mathrm{H}_{\mathrm{II}}\right)$ phosphatidylethanolamine, since the experiments have not been performed in systems with purified immunoglobulins and purified coagulation factors, but always in plasma (17, 79). Moreover, a possible interaction of hexagonal phase $\left(\mathrm{H}_{\mathrm{II}}\right)$ phosphatidylethanolamine with aCL antibodies has not yet been evaluated.

The frequent observation of reduced levels of prothrombin in the plasma of LA-positive patients led several authors to investigate whether LA antibodies could interact also with prothrombin. In this respect, it has been shown that non-neutralizing anti-prothrombin antibodies are present in a consistent percentage of LA-positive patients with both reduced and normal levels of prothrombin (44).

Recently, it has been demonstrated that LA-associated hypoprothrombinemia derives from the presence of prothrombin-antiprothrombin complexes, which are quickly scavenged from the circulation $(80,81)$. Based on the adsorption of LA antibodies from plasma by insolubilized prothrombin and the subsequent elution of the anticoagulant activity from the complex, Fleck and coworkers (81) suggested that LA antibodies may recognize unknown antigenic epitope(s) on prothrombin, thus implying that the immunological cross-reactivity of LA antibodies extends beyond phospholipids.

Interaction between antiphospholipid antibodies and cell membrane phospholipids

Anionic phospholipids are essential constituents of the plasma membranes of cells and they are usually located in the cytoplasmic leaflet. Thus, they are not available for antiphospholipid antibodies. However, under 
physiological conditions this asymmetric distribution can be lost, resulting in exposure of negatively-charged phospholipids on the outer membrane surface (82). For platelets this phenomenon occurs upon activation by different agonists and is accompanied by shedding of microvesicles (82). Activated platelets and platelet-derived microvesicles provide a catalytic surface for the interaction of coagulation factors and, in this way, acquire procoagulant properties $(82)$. Also endothelial cells $(83,84)$ and monocytes $(85,86)$ may become procoagulant, following stimulation with different kinds of agents.

Platelets, endothelial cells, monocytes and also lymphocytes are cells which play a pivotal role in the processes of haemostasis, thrombosis and inflammation. Thus, the interaction between antiphospholipid antibodies and the plasma membrane of these cells has been widely investigated, since it might result in the modulation of the cellular pro- and anticoagulant properties.

Binding of antiphospholipid antibodies to platelet membrane has been reported by some authors to occur with freeze-thawed (87), activated (88) and even resting $(33,89)$ platelets. In contrast, other authors failed to show any binding to the membrane of platelets (72). Anti-endothelial cell antibodies have been frequently reported in association with antiphospholipid antibodies mostly in patients with SLE, but the identity between these two types of antibodies has never been demonstrated $(90,91)$. Finally, the interaction of antiphospholipid antibodies with monocyte procoagulant activity (92), their binding to lymphocytes (93) or their elution from red blood cell membrane in patients with autoimmune haemolytic anaemia (94) have also been sporadically reported in the literature.

\section{3. “COFACTORS” FOR THE EXPRESSION OF LA ANTIBODIES}

The first report of the existence of a "cofactor" for the expression of LA antibodies was made already in 1959 by Loeliger (10). In fact, this author observed that the coagulation times of a mixture of normal with patient's plasma were more prolonged than that of the patient's own plasma. 
Characteristically, a low level of prothrombin was also found in the plasma of the patient. Experiments on adsorption of patient's plasma with $\mathrm{BaSO}_{4}$ led this author to suggest that prothrombin might be the "cofactor" of LA antibodies (10).

More work on the "cofactor" of LA antibodies was made in 1965 by Yin and Gaston (11). In contrast with Loeliger's findings, these investigators identified the "cofactor" activity in the gammaglobulin fraction. The molecule showed some peculiarities: it had a sedimentation coefficient of 6.6 Svedberg units, could be isolated from both normal and patient's plasma and was neither heat-stable nor adsorbed by $\mathrm{BaSO}_{4}(11)$.

In 1974 another group studied the properties of the "cofactor" of LA antibodies (95). The "cofactor" activity could be detected both in plasma and in serum of normal subjects, had an apparent molecular weight of $200 \mathrm{kD}$, was sparingly adsorbed by $\mathrm{Al}(\mathrm{OH})_{3}$ or $\mathrm{BaSO}_{4}$, stable at room temperature but largely destroyed by heating at $56^{\circ} \mathrm{C}$ for $30 \mathrm{~min}$. These properties were different from those of both prothrombin and a gammaglobulin.

Finally, in 1978 Exner et al. (15) suggested that the "cofactor" of LA antibodies might be a mere artefact, due to the presence in some LA-positive plasmas of residual platelets or platelet "dust". This extra procoagulant surface was diluted upon mixing of the patient's plasma with normal plasma, thus explaining why the coagulation times of the plasma mixture were longer than those of the patient's own plasma.

Over the years all the authors who developed new coagulation tests for the diagnosis of LA antibodies reported about the existence of a "cofactor" of LA antibodies. However, probably due to the controversial findings, no further attempts directed towards identification and characterization of the "cofactor" of LA antibodies were made.

\section{AIM OF THE STUDY}

The aim of the present study was to investigate the role of protein "cofactors" for the expression of the immunological activity of 
antiphospholipid antibodies. In particular:

- Chapter II evaluates the role of human prothrombin for the expression of LA activity in plasma;

- Chapter III describes the characterization of a protein in human (bovine) plasma (serum), which is necessary for the binding of aCL antibodies to cardiolipin and other negatively-charged phospholipids and its identification as $B_{2}$-Glycoprotein I;

- Chapter IV evaluates the role of $B_{2}$-Glycoprotein $I$ in the expression of the anticoagulant activity of aCL antibodies;

- Chapter V reports on the interaction of LA and aCL antibodies with the procoagulant activity of both platelets and platelet-derived microvesicles;

- Chapter VI gives a general discussion of the results.

\section{REFERENCES}

1. Landsteiner $\mathrm{K}$. The specificity of serological reactions. Revised edition, Harvard University Press, Cambridge, 1945.

2. Sachs $H$, Klopstock A. Die serologische differenzierung von lecithin und cholesterin (serological differentiation of lecithin and cholesterol). Biochem J 1925; 159: 491-98.

3. Alving CA. Antibodies to lipids and lipid membranes: reactions with phosphatidylcholine, cholesterol, liposomes and bromelin-treated erythrocytes. In: Phospholipid-binding antibodies. Harris EN, Exner T, Hughes GRV, Asherson. RA (eds), CRC Fress, 1991, pp 73-95.

4. Wassermann A, Neisser A, Bruck C. Eine serodiagnostische Reaktion bei Syphilis. Disch Med Wochenschr 1906; 19: 619-25.

5. Pangborn MC. A new serologically active phospholipid from beef heart. Proc Soc Exp Biol Med 1941; 48: 484-86.

6. Moore JE, Mohr CF. Biologically false positive serologic tests for syphilis: type, incidence and cause. J Am Med Association 1952; 150: 467-73.

7. Mueller JF, Ratnoff O, Heinle RW. Observations on the characteristics of an unusual circulating anticoagulant. J Lab Clin Med 1951; 38: 254-61.

8. Conley CL, Hartmann RC. Haemornhagic disorder caused by circulating anticoagulant in patients with disseminated lupus erythematosus. J Clin Invest 1952; 150: 621-22.

9. Frick PG. Acquired circulating anticoagulants in systemic collagen diseases. Autoimmune thromboplastin deficiency. Blood 1955; 10: 691-96.

10. Loeliger F. Prothrombin as co-factor of the circulating anticoagulant in systemic lupus cry thematosus? Thromb Diath Haemornh (Stuttg) 1959; 3: 237-56. 
11. Yin ET, Gaston LW. Purification and kinetic studies on a cisculating anticoagulant in a suspected case of lupus erythematosus. Thromb Diath Haemorrh (Stuttg) 1965; 14: 88-115.

12. Feinstein DI, Rapaport SI. Acquired inhibitors of blood coagulation. Prog Hemostas Thromb 1972; 1: 75-95.

13. Schleider MA, Nachman RL, Jaffe EA, Coleman M. A clinical study of the lupus anticoagulant. Blood 1976; 48: 499-509.

14. Laurell AB, Nilsson IM. Hypergammaglobulinemia, circulating anticoagulant and biological false positive Wassermann reaction: a study of two cases. J Lab Clin Med 1957; 49: 694-707.

15. Exner T, Rickard KA, Kronenberg H. A sensitive test demonstrating lupus anticoagulant and its behavioural patterns. Br J Haematol 1978; 40: 143-51.

16. Thiagarajan P, Pengo V, Shapiro SS. The use of the dilute Russell viper venom time for the diagnosis of lupus anticoagulant. Blood 1986; 68: 869-74.

17. Rauch J, Tannenbaum $M$, Janoff AS. Distinguishing plasma lupus anticoagulants from anti-factor antibodies using hexagonal (II) phase phospholipids. Thromb Haemostas 1989; 62: 892-96.

18. Green D, Hougie C, Kazmier FJ et al. Report on the working party on acquired inhibitors of coagulation: studies on the "Lupus" anticoagulant. Thromb Haemostas 1983; 49: $144-47$.

19. Exner T, Triplett DA, Taberner D, Machin SJ. Guidelines for testing and revised criteria for lupus anticoagulants. Thromb Haemostas 1991; 65: 320-22.

20. Triplett DA, Brandt JT, Kaczor D, Schaeffer J. Laboratory diagnosis of lupus inhibitors: a comparison of the tissue thromboplastin inhibition procedure with a new platelet neutralization procedure. Am J Clin Pathol 1983; 79: 678-82.

21. Kelsey PR, Stevenson KJ, Poller L. The diagnosis of lupus anticoagulants by the activated partial thromboplastin time - the central role of phosphatidylserine. Thromb Haemostas 1984; 52: 172-75.

22. Alving BM, Baldwin PE, Richards RL, Jackson BJ. The dilute phospholipid APTT: a sensitive assay for verification of lupus anticoagulants. Thromb Haemostas 1985; 54: 709-12.

23. Rosove MH, Ismail M, Koziol BJ et al. Lupus anticoagulants: improved diagnosis with a kaolin clotting time using rabbit brain phospholipid in standard and high concentrations. Blood 1986; 68: 471-78.

24. Branch DW, Rote NS, Scott JR. The demonstration of lupus anticoagulant by an enzyme-linked immunoadsorbent assay. Clin Immunol Immunopathol 1986; 39: 298-307.

25. Rosner E, Pauzner R, Lusky A et al. Detection and quantitative evaluation of lupus circulating anticoagulant activity. Thromb Haemostas 1987; 57: 144-47.

26. Brandt JT. Assays for phospholipid-dependent formation of thrombin and Xa: a potential method for quantifying lupus anticoagulant activity. Thromb : Iaemostas 1991; 66: 453-58.

27. Arnout J, Huybrechts E, Vanrusselt M, Vermylen J. A new lupus anticoagulant neutralization test based on platelet-derived vesicles. Br J Haematol 1992; 80: $341-46$.

28. Harris EN, Gharavi AE, Boey ML et al. Anticardiolipin antibodies: detection by 
radioimmunoassay and association with thrombosis in systemic lupus erythematosus. Lancet 1983; 1211-14.

29. Loizou S, McCrea JD, Rudge AC et al. Measurement of anticardiolipin antibodies by an enzyme-linked immunosorbent assay: standardization and quantitation of results. Clin Exp Immunol 1985; 62: 739-44.

30. Gharavi AE, Harris EN, Asherson RA, Hughes GRV. Anti-cardiolipin antibodies: isotype distribution and phospholipid specificity. Ann Rheum Dis 1987; 46: 1-5.

31. Lafer EM, Rauch J, Andrezejewski C et al. Polyspecific monoclonal lupus autoantibodies reactive with both polynucleotides and phospholipids. J Exp Med 1981; 153: 897-909.

32. Harris EN, Gharavi AE, Loizou $S$ et al. Crossreactivity of antiphospholipid antibodies. J Clin Lab Immunol 1985; 16: 1-6.

33. Hasselaar P, Derksen RHWM, Blokzijl L, de Groot P. Crossreactivity of antibodies directed against cardiolipin, DNA, endothelial cells and blood platelets. Thromb Haemostas 1990; 63: 169-73

34. Harris EN, Gharavi AE, Patel SP, Hughes GRV. Evaluation of the anti-cardiolipin antibody test: report of an international workshop held 4 April 1986. Clin Exp Immunol 1987; 68: $215-22$.

35. Harris EN. The second international anticardiolipin standardization workshop/The Kingston anti-phospholipid antibody study (KAPS) group. Am J Clin Pathol 1990; 94: 47684.

36. Bowie EJW, Thompson JH, Pascuzzi CA, Owen CA. Thrombosis in systemic lupus erythematosus despite circulating anticoagulants. J Lab Clin Med 1963; 62: 416-30.

37. Vermylen J, Blockmans D, Spitz B, Deckmin H. Thrombosis and immune disorders. Clin Haematol 1986; 15: 393-412.

38. Nilsson IM, Astedt B, Hedner U, Berezin D. Intrauterine death and circulating anticoagulant ("antithromboplastin"). Acta Med Scand 1975; 197: 153-59.

39. de Wolf F, Carreras LO, Moerman $P$ et al. Decidual vasculopathy and extensive placental infarction in a patient with repeated thromboembolic accidents, recurrent fetal loss and a lupus anticoagulant. Am J Obstet Gynaecol 1982; 142: 829-34.

40. Barbui T, Contelazzo S, Galli $M$ et al. Antiphospholipid antibodies in early repeated abortions: a case-control study. Fertil Steril 1988; 50: 589-92.

41. Finazzi G, Cortelazzo S, Galli M, Barbui T. Relative risk of recurrent abortion and thrombosis in young subjects with antiphospholipid antibodies estimated by case-control studies. Postgraduate Med J 1989; 65: 697.

42. Lechner K, Pabinger-Fasching I. Lupus anticoagulant and thrombosis. Hemostasis 1985; 15: 254-62.

43. Orlando E, Cortelazzo S, Marchetti $\mathrm{M}$ et al. Prolonged bleeding time in patients with lupus anticoagulant. Thromb Haemostas 1992; 68: 495-99.

44. Shapiro SS, Thiagarajan P. Lupus anticoagulants. Progr Hemostas Thromb 1982; 6: 263-86.

45. Harris EN. Syndrome of the Black swan. Br J Rheumatol 1987; 26: 324-6. 
46. Asherson RA. A "primary" antiphospholipid syndrome. J Rheumatol 1988; 15: 1742 -

44.

47. Asherson RA. Anti-phospholipid antibodies: clinical implications reported in medical literature. In: Phospholipid-binding antibodies. Harris EN, Exner T, Hughes GRV, Asherson RA (eds), CRC Press, 1991, pp. 387-401.

48. Carreras LO, Vermylen JG. "Lupus anticoagulant" and thrombosis - Possible role of inhibition of prostacyclin formation. Thromb Haemostas 1982; 48: 38-40.

49. Lellouche F, Martinuzzo M, Said P et al. Imbalance of thromboxane/prostacyclin biosynthesis in patients with lupus anticoagulant. Blood 1991; 78: 2894-99.

50. Comp PC, de Bault LE, Esmon NE, Esmon CP. Human thrombomodulin is inhibited by IgG from 2 patients with non-specific anticoagulants. Blood 1983; 62: 1099 (abstr).

51. Freyssinet JM, Gauchy J, Cazenave JP. The effect of phospholipids on the activation of protein $\mathrm{C}$ by the human thrombin-thrombomodulin complex. Biochern J 1986; 238: 151-57.

52. Cariou $M$, Tobelem G, Bellucci $S$ et al. Effect of lupus anticoagulant on antithrombogenic properties of endothelial-cells - Inhibition of thrombomodulin-dependent protein C activation. Thromb Haemostas 1988; 60: 54-58.

53. Tannenbaum SH, Finko R, Cines DB. Antibody and immune complexes induce tissue factor production by human endothelial cells. J Immunol 1986; 137: 1532-37.

54. Rustin MHA, Bull HA, Machin SJ et al. Effect of the lupus anticoagulant in patients with systemic lupus erythematosus on endothelial cell prostacyclin and procoagulant activity. $J$ Invest Dermatol 1988; 90: 744-48.

55. Hasselaar P, Derksen RHWM, Oosting JD et al. Synergistic effect of low doses of tumor necrosis factor and sera from patients with systemic lupus erythematosus on the expression of procoagulant activity by cultured endothelial cells. Thromb Haemostas 1989; 62: 654-50.

56. Galli $\mathrm{M}$, Cortelazzo $\mathrm{S}$, Viero $\mathbf{P}$ et al. Interaction between platelets and lupus anticoagulant. Eur J Haematol 1988; 41: 88-94.

57. Tsakiris DA, Marbert GA, Makris PE. Impaired fibrinolysis is an essential contribution to thrombosis in patients with lupus anticoagulant. Thromb Haemostas 1989; 61: 175-77.

58. Cosgriff TM, Martin BA. Low functional and high antigenic antithrombin III level in a patient with the lupus anticoagulant and recurrent thrombosis. Arthritis Rheum 1981; 24: 9496.

59. Sanfelippo MJ, Drayana CJ. Prekallikrein inhibition associated with the lupus anticoagulant. Am J Clin Pathol 1982; 77: 275-79.

60. Friedman $\mathrm{KD}$, Marlar RA, Gill JC et al. Protein S deficiency in patients with the lupus anticoagulant. Blood 1986; 68: 333a (abstr).

61. Falanga A, Ofosu FA, Cortelazzo $S$ et al. Hemostatic system activation in patients with lupus anticoagulant and essential thrombocytemia. Seminars Hemostas Thromb (in press).

62. Blank M, Cohen J, Toder V, Shoenfeld Y. Induction of anti-phospholipid syndrome in naive mice with mouse lupus monoclonal and human polyclonal anti-cardiolipin antibodies. Proc Natl Acad Sci USA 1991; 88: 3069-73.

63. Branch DW, Dudley DJ, Mitchell KA et al. Immunoglobulin G fractions from patients 
with antiphospholipid antibodies cause fetal death in BALB/c mice: a model for autoimmune fetal loss. Am J Obstet Gynecol 1990; 163: 210-16.

64. Gharavi AE, Mellors RS, Elkon KB. IgG anticardiolipin antibodies in murine lupus. Clin Exp Immunol 1989; 78: 233-40.

65. Bakimer $\mathrm{R}$, Fishman $\mathrm{P}, \mathrm{Blank} \mathrm{M}$ et al. Induction of primary antiphospholipid syndrome in mice by immunization with a monoclonal anticardiolipin antibody $(\mathrm{H}-3)$. J Clin Invest 1992; 89: 1558-63.

66. Hashimoto $\mathrm{Y}$, Kawamura $\mathrm{M}$, Ichikawa $\mathrm{K}$ et al. Anticardiolipin antibodies in NZW $\mathrm{x}$ BXSB FI mice. J Immunol 1992; 149: 1063-68.

67. Cooper MR, Cohen HJ, Huntley $\mathrm{CC}$ et al. A monoclonal IgM with antibodylike specificity for phospholipids in a patient with lymphoma. Blood 1974; 43: 493-504.

68. Staub HL, Harris EN, Khamashta MA et al. Antibody to phosphatidylethanolamine in a patient with lupus anticoagulant and thrombosis. Ann Rheum Dis 1989; 48: 166-69.

69. Shoenfeld $\mathrm{X}$, Rauch J, Massicotte $\mathrm{H}$ et al. Polyspecificity of monoclonal lupus autoantibodies produced by human-human hybridomas. N Engl J Med 1983; 308: 414-20.

70. Smeenk RJT, Lucassen WAM, Swaak TJG. Is anticardiolipin activity a cross-reaction of anti-DNA or a separate entity? Arthritis Rheum 1987; 30:607-17.

71. Harris EN, Gharavi AE, Tincani A et al. Affinity-purified anti-cardiolipin and antiDNA antibodies. I Clin Lab Immunol 1985; 17: 155-62.

72. Thiagarajan P, Shapiro SS, de Marco L. A monoclonal immunoglobulin M coagulation inhibitor with phospholipid specificity: mechanism of a lupus anticoagulant. J Clin Invest 1980; 66: 397-405.

73. Pengo $V$, Thiagarajan $P$, Shapiro SS, Heine MJ. Immunological specificity and mechanism of action of IgG lupus anticoagulants. Blood 1987; 70: 69-76.

74. Exner T, Sahman N, Trudinger B. Separation of anticardiolipin from lupus anticoagulant on a phospholipid polystyrene column. Biochim Biophys Res Commun 1988; 15.5: 1001-07.

75. McNeil HP, Krilis SA, Chesterman CN. Purification of antiphospholipidid antibodies using a new affinity method. Thromb Res 1988; 52: 641-48.

76. McNeil HP, Chesterman CN, Krilis SA. Anticardiolipin antibodies and lupus anticoagulants comprise separate antibody subgroups with different binding characteristics. $\mathrm{Br}$ J Haematol 1989; 73: 506-136.

77. Janoff AS, Rauch J. The structural specificity of anti-phospholipid antibodies in autoimmune disease. Chem Phys Lipids 1986; 40: 315-32.

78. Cullis PR, Hope MJ, de Knijff B et al. Structural properties and functional roles of phospholipids in biological membranes. In: Phospholipids and cellular regulation. Kuo JF (ed), CRC Press, 1985; 1-28.

79. Rauch J, Tannenbaum $M$, Tannenbaum $H$ et al. Human hybridoma lupus anticoagulants distinguish between lamellar and hexagonal phase lipid systems. J Biol Chem $1986 ; 261: 9672-77$.

80. Edson JR, Vogt JM, Hasegawa DK. Abnormal prothrombin crossedimmunoelectrophoresis in patients with lupus anticoagulants. Blood 1984; 64: 807-16. 
81. Fleck RA, Rapaport SI, Rao VM. Anti-prothrombin antibodies and lupus anticoagulant. Blood 1988; 72: 512-19.

82. Schroit AJ, Zwaal RFA. Transbilayer movement of phospholipids in red cell and platelet membrane. Biochim Biophys Acta 1991; 1071: 313-29.

83. Colucci $\mathbf{M}$, Balconi $G$, Lorenzet $R$ et al. Cultured human endothelial cells generate tissue factor in response to endotoxin. J Clin Invest 1983; 71: 1893-96.

84. Nawroth PP, Sterm DM. Modulation of endothelial cell hemostatic properties by tumor necrosis factor. J Exp Med 1986; 163: 740-45.

85. Rothberger HT, Zimmermann HL, Spiegelberg HL et al. Leucocyte procoagulant activity. Enhancement of production in vitro by $\operatorname{IgG}$ and antigen-antibody complexes. J Clin Invest 1977; 5: 549-57.

86. Rivers RPA, Hathaway WE, Weston WL. The endotoxin-induced coagulant activity of human monocytes. Br J Haematol 1975; 30: 311-16.

87. Khamashta MA, Harris EN, Gharavi AE et al. Immune mediated mechanism for thrombosis: antiphospholipid antibody binding to platelet membranes. Ann Rheum Dis 1988; 47: 849-52.

88. Mikhail MH, Szczech LAM, Shapiro SS. The binding of lupus anticoagulant (LAC's) to human platelets. Blood 1988; 72: 333a (abstr).

89. Out $\mathrm{HJ}$, de Groot $\mathbf{P}$, van Vliet $M$ et al. Antibodies to platelets in patients with antiphospholipid antibodies. Blood 1991; 77: 2655-59.

90. Vismara A, Meroni PL, Tincani A et al. Relationship between anti-cardiolipin and antiendothelial cell antibodies in systemic lupus erythematosus. Clin Exp Immunol 1988; 74: 24753.

91. McCrae KR, De Michele A, Samuels $P$ et al. Detection of endothelial cell-reactive immunoglobulin in patients with anti-phospholipid antibodies. $\mathrm{Br} \mathrm{J}$ Hae.natol 1991; 79: 595605 .

92. de Prost V, Ternisien C, Chollet-Martin S. Increased monocyte procoagulant activity independent of the lupus anticoagulant in patients with systemic lupus erythematosus. Thromb Haemostas 1990; 64: 216-21.

93. Misra R, Venables PJW, Plater-Zyberk C et al. Anti-cardiolipin antibodies in infectious mononucleosis react with the membrane of activated lymphocytes. Clin Exp Immunol 1989; 75: $35-40$.

94. Arvieux J, Schweitzer B, Roussel B, Colomb MG. Autoimmune haemolytic anaemia due to anti-phospholipid antibodies. Vox Sang 1991; 61: 190-95.

95. Rivard GE, Schiffman S, Rapaport SI. Cofactor of the "Lupus anticoagulant". Thromb Diath Haemorrh (Stuttg) 1974; 32: 554-63. 



\section{CHAPTER II}

LUPUS ANTICOAGULANT IgG's (LA) ARE NOT DIRECTED TO PHOSPHOLIPIDS ONLY, BUT TO A COMPLEX OF LIPIDBOUND HUMAN PROTHROMBIN

based on:

Bevers EM, Galli M, Barbui T, Comfurius P, Zwaal RFA.

Thromb Haemostas 1991; 66: 629-32 


\section{SUMMARY}

Plasmas from 16 patients that were found to be positive for both anticardiolipin (aCL) and lupus anticoagulant (LA) antibodies were incubated with liposomes that contained anionic phospholipids. In 11 of these plasmas, $\mathrm{aCL}$ antibodies could be co-sedimented with the liposomes in a dose-dependent manner, whereas LA activity of the remaining supernatant was unaffected. LA activity of purified total IgG from 6 patients was measured in three different coagulation tests, using normal plasmas from different species. Prolongation of the aPTT, KCT and dRVV clotting times was observed only with normal plasma from human origin, not with bovine, rat or sheep plasma.

Highly purified coagulation factors $\mathrm{Xa}, \mathrm{Va}$ and prothrombin, both of human and bovine origin, were used to establish for two patient IgG's the effect of LA antibodies on the rate of thrombin formation in the presence and absence of lipid vesicles composed of 20 mole\% phosphatidylserine and 80 mole\% phosphatidylcholine. A strong and dose dependent inhibition by LA antibodies was observed only when human prothrombin was used as substrate in the prothrombinase complex in the presence of lipids. No inhibition was found when bovine prothrombin was used as substrate. The inhibitory effect observed in the presence of human prothrombin was independent of the source of factors $\mathrm{Xa}$ and $\mathrm{Va}$, and was not found in the absence of lipid. Binding studies show that LA antibodies only associate with a lipid surface, provided that human prothrombin and calcium ions are present. These data indicate that LA antibodies are not directed to phospholipids alone, but presumably recognize an epitope which becomes exposed upon $\mathrm{Ca}^{2+}$-mediated binding of human prothrombin to phospholipids.

\section{INTRODUCTION}

A characteristic feature of plasma from patients with the AntiPhospholipid Syndrome (APS) is the occurrence of antibodies to anionic phospholipids (anticardiolipin, aCL, antibodies) frequently in combination 
with so-called lupus anticoagulant (LA) antibodies (1). aCL antibodies are usually detected by solid phase immunoassays as described by Loizou et al. (2), whereas LA antibodies are measured as an activity which prolongs lipiddependent coagulation reactions assayed by standard techniques such as aPTT, $\mathrm{KCT}$ and dRVV (3). Since it is generally assumed that in these assays the prolonged clotting time is due to lipid-directed antibodies that compete for the binding of coagulation factors to the phospholipid surface, it has been suggested that both antibodies may be identical $(4,5)$.

However, several studies have indicated that at least in a number of patients aCL can be separated from LA antibodies $(6,7)$. Recently, it was found that interaction of aCL antibodies with cardiolipin as well as other anionic phospholipids requires the presence of beta 2 -glycoprotein I ( $B_{2}$-GPI) $(8,9$ and Chapter III of this thesis). This protein, which is present in normal plasma, was shown to have anticoagulant properties $(10,11)$. During our studies on the role of $B_{2}$-GPI in promoting the binding of aCl antibodies to negatively charged phospholipids, we noticed that selective removal of aCL antibodies from plasma of patients with both LA and aCL antibodies did not affect the LA activity of these plasmas. Furthermore, in their studies on separated aCL and LA antibodies, McNeil et al. found that antibodies responsible for LA activity do not bind to isolated phospholipids in solid phase immunoassays, and conversely that aCL antibodies do not possess LA activity as measured by aPTT and KCT (7).

The present study was undertaken to elucidate the mechanism by which LA antibodies cause prolongation of the clotting time of lipid-dependent coagulation reactions. We have used highly purified human and bovine coagulation factors to study the effect of LA IgG from two different patients on the rate of thrombin formation. Evidence is presented that LA antibodies are not directed to phospholipids alone, but recognize an epitope on lipidbound prothrombin. 


\section{MATERIALS AND METHODS}

\section{Patients}

Initially, we studied 16 patients, who were found to be seropositive for aCL and LA antibodies as determined by standard solid phase immunoassay (2) and aPTT or dRVV (3). Of the patients whose LA activity was distinct from aCL (see Fig. 1), two men (aged 52 and 39) were selected for further investigation of the mode of action of LA antibodies. One of them showed symptoms of superficial thrombophlebitis, while the other had suffered from recurrent peripheral thrombosis. None of them fulfilled criteria for diagnosis of SLE (12).

\section{Separation of $L A$ from aCL antibodies}

Liposomes, used to investigate whether aCL antibodies could be separated from LA antibodies, were composed of a mixture of cardiolipin, phosphatidylcholine and cholesterol in a molar ratio of 2.5:10:4, respectively. When cardiolipin in these liposomes was replaced by phosphatidylserine, twice the amount of the latter lipid was used. All lipids were from Sigma, St Louis, MO. Liposomes were added to patient plasma and after incubation for $30 \mathrm{~min}$ at $37{ }^{\circ} \mathrm{C}$ they were removed by centrifugation for $10 \mathrm{~min}$ at $12,000 \mathrm{x}$ g. The liposome-free supernatant was analysed for aCL antibodies, essentially following the procedure of Loizou et al. (2). LA activity was measured by aPTT (3), using a mixture of 1 vol supernatant and 2 vol normal plasma. No difference in aPTT clotting time was found between the supernatant of normal plasma treated with liposomes and normal plasma treated with an equal volume of Tris buffer. This indicates that traces of lipid material left in the patient plasma after liposome extraction did not interfere with the aPTT. The aPTT was performed using Thrombofax (Ortho diagnostics) according to the manufacturers' instructions. KCT was carried out as described by Exner et al. (13) and dRVV as described by Thiagarajan et al. (14).

\section{Purification of $\lg G$}

IgG was isolated from patient plasma by affinity chromatography using 
protein A-sepharose CL 4B (Pharmacia Fine, Uppsala, Sweden). These preparations were found to retain both $\mathrm{aCL}$ and LA activity.

\section{Measurement of prothrombinase activity}

For measuring prothrombinase activity, highly purified coagulation factors of human and bovine origin were used. Coagulation factors $\mathrm{Xa}, \mathrm{Va}$ and prothrombin were purified from bovine plasma as described by Rosing et al. (15) and from human plasma as described by Tans et al. (16). As lipid source in the assay, we have used unilamellar vesicles, prepared by sonication in "tris"-buffered saline (TBS; $0.05 \mathrm{~mol} / \mathrm{l}$ tris, $0.1 \mathrm{~mol} / \mathrm{l} \mathrm{NaCl}, \mathrm{pH} \mathrm{7.4)}$ ) of a mixture composed of 20 mole\% phosphatidylserine and 80 mole\% phosphatidylcholine. Prothrombinase activity was measured essentially according to ref. 17, with minor modifications. The prothrombinase assay was performed in TBS ( $\mathrm{pH} 7.4$ ) containing $0.5 \mathrm{mg} / \mathrm{ml}$ human serum albumin (essentially fatty acid-free, Sigma, St Louis) as follows: $125 \mu$ prothrombin $(4 \mu \mathrm{mol} / \mathrm{l})$ was preincubated for $5 \mathrm{~min}$ at $37^{\circ} \mathrm{C}$ with $250 \mu \mathrm{l}$ lipid vesicles $(1.2$ $\mu \mathrm{mol} / \mathrm{l})$ in the presence of $25 \mu \mathrm{l} 60 \mathrm{mmol} / / \mathrm{CaCl}_{2}$ and $50 \mu \mathrm{l}$ normal or patient $\mathrm{IgG}$ (concentration as indicated in the text). Thrombin formation was initiated by addition of $50 \mu \mathrm{l}$ of a mixture of factor $\mathrm{Xa}$ and $\mathrm{Va}(1.0$ and $2.0 \mathrm{nmol} / \mathrm{h}$, respectively). In case the prothrombinase activity was measured in the absence of phospholipid, the concentrations of factor $\mathrm{Xa}$ and $\mathrm{Va}$ were chosen 10-fold higher. At different time intervals, $25 \mu \mathrm{l}$ aliquots were transferred from the prothrombinase mixture to a cuvette containing $1.0 \mathrm{ml}$ TBS/EDTA (2.0 $\mathrm{mmol} / \mathrm{EDTA}$ ), $\mathrm{pH} 7.4$, to stop the reaction. Thrombin-specific chromogenic substrate S2238 (Kabi diagnostics, Stockholm) was added at a final concentration of $250 \mu \mathrm{mol} / \mathrm{h}$ and from the change in absorbance at $405 \mathrm{~nm}$ the amount of thrombin was calculated using a calibration curve made with known amounts of active site titrated thrombin (15).

\section{Binding experiments}

To investigate whether human prothrombin was required for the binding of LA antibodies to a procoagulant surface, red blood cell (RBC) ghosts, prepared according to Bevers et al. (18) were used. RBC ghosts were chosen 
because they provide a readily sedimentable procoagulant surface. Briefly: 10 $\mu \mathrm{l} \mathrm{LA} \mathrm{IgG} \mathrm{(} 1 \mathrm{mg} / \mathrm{ml}$ final concentration) were mixed with $150 \mu \mathrm{l} \mathrm{RBC}$ ghosts at various concentrations and $40 \mu \mathrm{l}$ human prothrombin (final concentration 2 $\mu \mathrm{mol} / \mathrm{l}$ ) in Hepes buffer containing $3 \mathrm{mmol} / \mathrm{l} \mathrm{CaCl} 2$. After $15 \mathrm{~min}$ incubation at $37^{\circ} \mathrm{C}$ the mixture was centrifuged at $12,000 \times \mathrm{g}$ for $5 \mathrm{~min}$ and the supernatants were analyzed for the residual LA activity as well as prothrombin.

Prothrombin was measured after its conversion to thrombin by Echis carinatus venom, using the thrombin-specific chromogenic substrate S2238. Under the conditions described, up to $40 \%$ of the prothrombin binds to the RBC ghosts at the highest ghost concentration used. This value was not affected when either LA or non-specific IgG was present. Therefore, the supernatants of the binding experiments could be used subsequently as a source of prothrombin in the prothrombinase assay, taking care that the amount of prothrombin in the assay is adjusted to the same final concentration $(2 \mu \mathrm{mol} / \mathrm{m})$ by addition of "exogenous" prothrombin.

LA activity was evaluated by its inhibitory activity in the prothrombinase assay. This assay was performed essentially as described above. Briefly: $60 \mu \mathrm{l}$ supernatant of each binding experiment (adjusted to the same prothrombin concentration: see above) were incubated with $10 \mu \mathrm{l} 3 \mu \mathrm{mol} / \mathrm{l} \mathrm{PS} / \mathrm{PC}$ vesicles (molar ratio 20/80) in the presence of $3 \mathrm{mmol} / / \mathrm{CaCl}_{2}$. After $10 \mathrm{~min}$ at $37^{\circ} \mathrm{C}$ $10 \mu \mathrm{l}$ bovine $\mathrm{Xa}$ and $\mathrm{Va}$ ( 1 and $2 \mathrm{nmol} / \mathrm{l}$ final concentration, respectively) were added to start prothrombin conversion. After $2 \mathrm{~min}, 25 \mu \mathrm{l}$ of the incubation mixture were transferred to a cuvette containing $1 \mathrm{ml}$ TBS/EDTA (2 mmol/l EDTA), pH 7.4, to stop the reaction. $\mathrm{S} 2238$ was added at a final concentration of $250 \mu \mathrm{mol} / \mathrm{l}$ and from the change in absorbance at $405 \mathrm{~nm}$ the amount of thrombin was calculated using a calibration curve made with known amounts of active site titrated thrombin. 


\section{RESULTS AND DISCUSSION}

Plasmas from 16 patients with both LA and aCL activity were incubated with liposomes containing either cardiolipin or phosphatidylserine. After removal of the liposomes by centrifugation, the remaining plasma supernatants were tested for $\mathrm{aCL}$ and LA activity. In 11 out of these 16 plasmas, it appeared possible to reduce the aCL titer without affecting the LA activity. In the remaining 5 patient plasmas, LA activity co-sedimented with $\mathrm{aCL}$ antibodies and liposomes. As explained in Chapter IV, these plasmas contain aCL antibodies which express an anticoagulant activity that is dependent on $B_{2}$-Glycoprotein I ( $\left.B_{2}-G P I\right)$. In the present study, we have focused on LA antibodies from which aCL antibodies can be separated by liposome extraction. Fig. 1 shows data from a representative experiment in which the loss of $\mathrm{aCL}$ antibodies was a function of the amount of liposomes added to the plasma. Essentially the same results were obtained when cardiolipin-containing liposomes were substituted by other commercially available phospholipid preparations used for standard coagulation assays (Actin from Dade and Thrombofax from Ortho diagnostics). Furthermore, it is obvious that in this group of patients LA antibodies are unable to bind to a lipid surface which contains anionic phospholipids. These findings are consistent with earlier reports by Exner et al. (6) and McNeil et al.(7) demonstrating that aCL and LA antibodies comprise separate antibody subgroups.

In order to test the possibility that binding of LA antibodies to anionic phospholipid would require calcium ions, we incubated affinity-purified total IgG with the same phospholipid preparations either in the presence or absence of calcium. None of the phospholipid preparations were able to reduce the LA content of the total IgG, irrespective of the presence of calcium ions. This observation makes it unlikely that prolongation of the clotting time by LA antibodies is caused by a calcium-dependent interaction of LA antibodies to the lipid surface.

These results led us to investigate whether a protein-cofactor might be required for interaction of LA antibodies with phospholipid. 


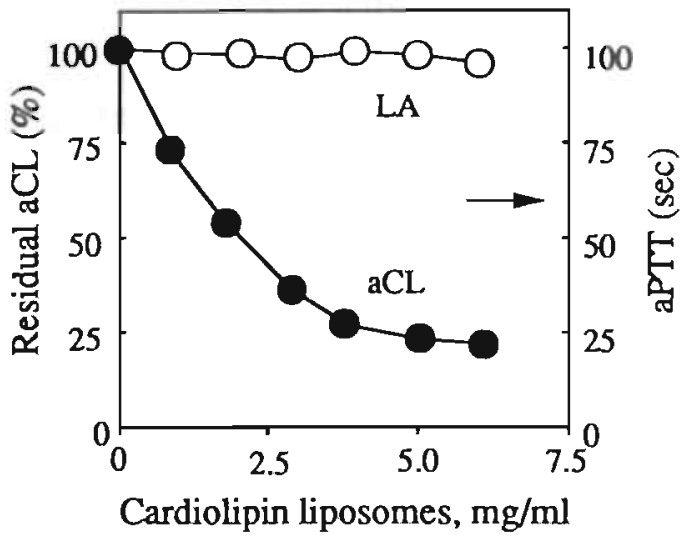

Fig. 1. Selective removal of aCL antibodies from patient plasma by adsorption 10 liposomes containing cardiolipin (or phosphatidylserine). After sedimentation of the liposomes, $a C L$ and $L A$ antibodies are determined in the plasma supernatant by ELISA and aPTT, respectively. Arrow indicates aPTT cloting time of normal plasma.

Table I. LA activities of total IgG's in various coagulation assays using human and bovine plasma

\begin{tabular}{|c|c|c|c|c|c|c|}
\hline \multirow[t]{2}{*}{ Sample } & \multicolumn{2}{|c|}{$\operatorname{aPTT}(\mathrm{s})$} & \multicolumn{2}{|l|}{$\underline{\mathrm{KCT}}(\mathrm{s})$} & \multicolumn{2}{|c|}{ dRVVT (s) } \\
\hline & Human & Bovine & Human & Bovine & Human & Bovine \\
\hline Tris/ $/ \mathrm{NaCl}$ & 159.5 & 75.9 & 105.6 & 108.0 & 58.7 & 35.8 \\
\hline $\mathrm{N}-\mathrm{IgG}$ & 60.1 & 78.2 & 112.0 & 105.4 & 59.8 & 35.2 \\
\hline Pat. 1 & 74.2 & 77.3 & 142.0 & 110.2 & 74.2 & 35.4 \\
\hline Pat. 2 & 96.4 & 79.6 & 154.5 & 113.0 & 71.1 & 35.5 \\
\hline Pat. 3 & 72.0 & 76.0 & 134.5 & 109.4 & 62.7 & 37.5 \\
\hline Pat. 4 & 81.1 & 76.2 & 176.9 & 106.0 & 87.5 & 36.0 \\
\hline Pat. 5 & 92.2 & 78.0 & 184.2 & 110.1 & 86.7 & 36.1 \\
\hline Pat. 6 & 117.0 & 77.4 & 270.4 & 108.5 & 123.4 & 35.0 \\
\hline
\end{tabular}

To this end, LA activity of purified total IgG from 6 out of the 11 previously selected patients was measured in three different coagulation assays, an aPTT, a KCT and a dRVV using either normal human plasma or bovine plasma. In all three assays and with all patient IgG's, prolongation of the clotting time was found only when human plasma was used (Table I). Lack of inhibition was also found with sheep or rat plasma (data not shown). Similar 
observations have been reported earlier by Clyne in studies in which patient plasmas were mixed with animal plasmas (19). It was also excluded that lack of inhibition was related to different levels of coagulation factors in the animal plasmas (19). Since it is highly unlikely that the conformation of the lipid surface will depend on the plasma source, these results further confirm that LA antibodies do not directly bind to lipid. On the contrary, these data strongly suggest that a species-specific plasma component is required for expressing LA activity.

Of the three different clotting assays described in Table I, the dRVV is critically dependent on the conversion of prothrombin to thrombin by factors $\mathrm{Xa}$ and $\mathrm{Va}$ (3). We therefore investigated for two patients the effect of LA antibodies on the prothrombinase reaction using highly purified coagulation factors of both human and bovine origin. First we confirmed that aCL antibodies, purified as described by Galli et al. (9), have no effect on the prothrombinase assay. Purified aCL antibodies, free of LA activity as determined by $\mathrm{dRVV}$, did not inhibit the prothrombinase assay up to concentrations of $150 \mu \mathrm{g} / \mathrm{ml}$. Thus, no further attempts were made to obtain an $\mathrm{aCL}$ antibody-free LA preparation to perform the experiments described below. Total patient IgG showed a dose-dependent inhibition of the prothrombinase activity in a system with human coagulation factors $\mathrm{Xa}, \mathrm{Va}$ and prothrombin in the presence of lipid vesicles composed of 20 mole\% phosphatidylserine and 80 mole\% phosphatidylcholine (Fig. 2A). In contrast, no inhibitory effect was observed when human prothrombin was replaced by bovine prothrombin. When the human coagulation factors $\mathrm{Xa}$ and $\mathrm{Va}$ were substituted by the corresponding bovine factors, the same result was obtained, i.e. inhibition was only observed with human prothrombin, not with bovine prothrombin (Fig. 2B). Also, purified total $\mathrm{IgG}$ from another patient was found to inhibit the prothrombinase assay only when human prothrombin was used as a substrate. It should be emphasized that when phospholipid was omitted from the prothrombinase assay, no appreciable inhibition by total IgG was observed, irrespective of whether human or bovine prothrombin was used as a substrate. 


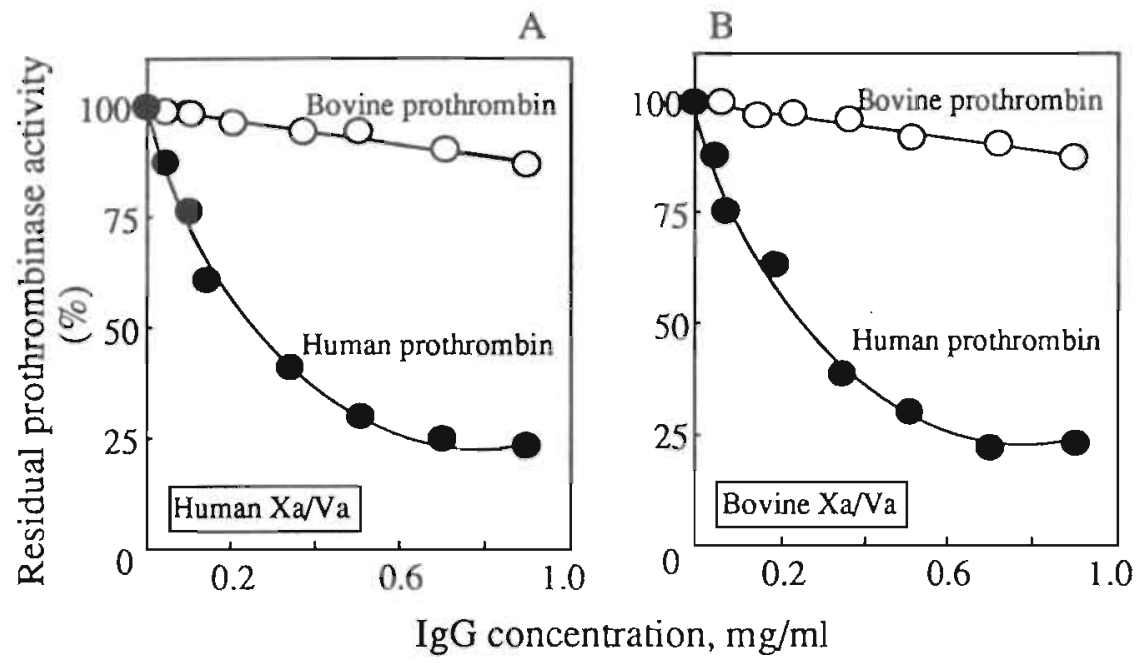

Fig. 2. Concentration-dependent inhibition of the prothrombinase assay by affinity-purified patient $\lg G$. Note that in panel A prothrombinase is composed of human factors Xa and Va and in panel $B$ of bovine factors $X a$ and $V a$.

In summary, the results presented in this paper clearly indicate that expression of LA activity requires the presence of both anionic phospholipids and human prothrombin. Apparently, these antibodies are not directed to phospholipids alone. Also the possibility that the antibodies interact with a putative lipid structure that is modified by binding of prothrombin is extremely unlikely, because such a modification would be expected to be independent of the species-origin of prothrombin. Two alternatives remain: (i) LA antibodies recognize an epitope which becomes exposed upon $\mathrm{Ca}$-mediated binding of prothrombin to anionic phospholipid, or (ii) L.A antibodies can bind an epitope on prothrombin which prevents the latter from interacting with phospholipids.

To investigate which of these two possibilities could account for the inhibitory effect of LA antibodies, we performed direct binding experiments in which LA and prothrombin were incubated with a readily sedimentable procoagulant phospholipid surface, i.e. red blood cell (RBC) ghosts. Under the conditions described in the method section, up to $40 \%$ of the prothrombin binds to the RBC ghosts at the highest ghost concentration used. This value 
was not affected when either LA or non-specific IgG was present. Thus, the binding of prothrombin to the lipid surface is not prevented by LA. IgG. LA activity was evaluated by its inhibitory activity in the prothrombinase assay. Fig. 3 shows the LA activity of the supernatant as a function of the concentration of RBC ghosts. When LA was incubated with R.BC ghosts in the absence of prothrombin, LA activity of the supernatant remained unchanged. However, when the incubation of the RBC ghosts was carried out in the presence of human prothrombin, a progressive loss of LA activity of the supernatant was observed when the antibodies were incubated with increasing concentrations of RBC ghosts. It has to be emphasized that this decrease was only found when $\mathrm{CaCl}_{2}$ was present during the binding step. From these data we conclude that LA antibodies recognize the complex of phospholipid-bound human prothrombin, in this way producing prolongation of phospholipiddependent coagulation tests.

In the past decades, a possible involvement of prothrombin in expression of LA activity has been surmized by different laboratories. Already in 1959, Loeliger proposed that prothrombin should be considered a cofactor for LA antibodies (20). Indeed, a remarkably high prevalence of associated anti-prothrombin antibodies has been reported for LA-positive plasmas, frequently associated with low levels of prothrombin in these plasmas $(21,22)$. Fleck and coworkers (22) suggested that these antibodies exhibit

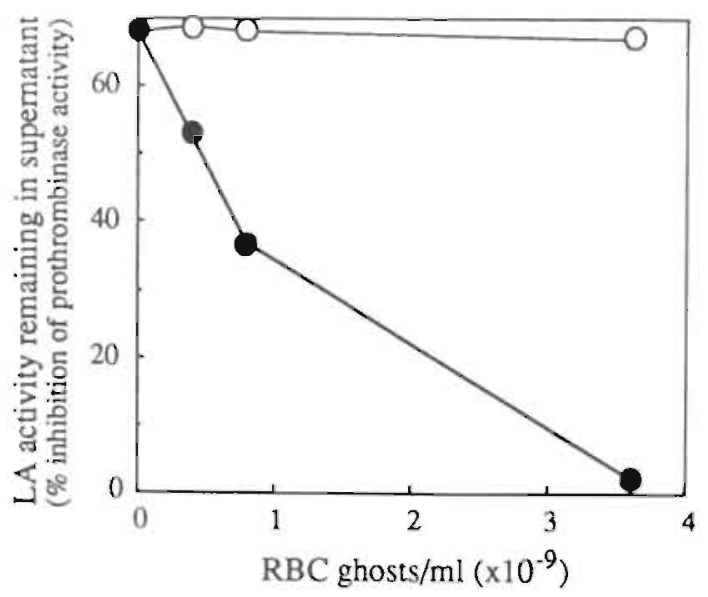

Fig 3. Binding of $\mathrm{LA} \mathrm{IgG}$ to $R B C$ ghosts. LA activity was determined by the inhibitory effect of the supernatant on the prothrombinase assay, as described in the text. Open circles represent the LA activities remaining in the supernatan after incubation with the RBS ghosts in the absence of prothrombin; closed circles represent the LA activities of the supernatant after incubation with the ghosts in the presence of human prothrombin. Binding was carried out in the presence of $3 \mathrm{mmol} / \mathrm{l}$ Calcium. 
polyreactivity including to epitopes on prothrombin. A reduced level of prothrombin (approximately 60\%) was also found in the plasma of the patient whose LA effect on the prothrombinase assay is shown in Fig. 2. However, the prothrombin concentration in the plasma of the other patient, whose LA antibodies showed essentially the same effect on the prothrombinase assay, was found to be normal. At present, it is difficult to ascertain to what extent reduced levels of prothrombin in these patients arise from antibodies directed to lipid-bound prothrombin, or to prothrombin not associated to lipid. Our results are not necessarily in contradiction to those of Rivard and coworkers (23), who concluded that LA-cofactor activity of normal plasma was dissimilar from prothrombin. They studied a patient with a classical SLE, whose plasma was LA positive, but it is unclear whether this plasma also contained separable or non-separable aCL activity. Moreover, their results could also be explained by a bypass effect caused by platelet contamination in the plasmas, as discussed by Exner and Triplett (3).

If LA antibodies are indeed directed to a prothrombin/phospholipid complex, one could consider prothrombin to be the counterpart of $B_{2}$-GPI in the binding of aCL antibodies to phospholipid (8,9 and Chapter III of this thesis). In this respect it is tempting to speculate that the underlying mechanism of antiphospholipid syndrome is an increased expression of procoagulant lipid surfaces, e.g. caused by complement-induced endothelial cell damage or platelet activation and microparticle formation $(24,25)$. The immune response does not necessarily have to be directed to anionic phospholipids, but could be focused on plasma proteins which bind to these lipids thus exposing cryptic epitopes. Both prothrombin and $B_{2}$-GPI are likely candidates, because they are abundant in plasma (approx. $2.5 \mu \mathrm{mol} / \mathrm{l}$ and 4 $\mu \mathrm{mol} / 1$, respectively) and have a relatively high affinity for anionic phospholipids. This hypothesis also offers a possible explanation for the frequently observed concurrent expression of $\mathrm{LA}$ and $\mathrm{aCL}$ antibodies in the antiphospholipid syndrome. Caution should be exercised, however, in making generalizations, because there are patients in whose plasmas aCL and LA antibodies cannot be separated into two different immunoglobulin fractions. The study of these antibodies in systems using purified coagulation factors and 
well defined phospholipids may contribute to a better understanding of their mode of action.

\section{REFERENCES}

1. Harris NE, Balestrieri G, Tincani A, Gharavi AE. The immunology of phospholipidbinding antibodies in the antiphospholipid syndrome and related disorders. In: Harris EN, Exner T, Hughes GRV, Asherson RA, eds. Phospholipid-binding antibodies. CRC Press, Inc. 1991: pp 123-137.

2. Loizou S, McCrea JD, Rudge AC et al. Measurement of anti-cardiolipin antibodies by an enzyme-linked immunosorbent assay: standardization and quantitation of results. Clin Exp Immunol 1985; 62: 738-44.

3. Exner T, Triplett D. Lupus anticoagulants: characteristics, methods of laboratory detection and some clinical associations. In: Harris EN, Exner T, Hughes GRV, Asherson RA, eds. Phospholipid-binding antibodies. CRC Press, Inc. 1991: pp 141-158.

4. Pengo V, Thiagarajan P, Shapiro SS, Heine MJ. Immunological specificity and mechanism of action of IgG lupus anticoagulants. Blood 1987; 70: 69-76.

5. Harris EN, Gharavi AE, Tincani A et al. Affinity purified anti-cardiolipin and anti-DNA antibodies. J Clin Lab Immunol 1985; 17: 155-62.

6. Exner T, Sahman N, Trudinger B. Separation of anticardiolipin antibodies from lupus anticoagulant on a phospholipid-coated polystyrene column. Biochem Biophys Res Commun 1988; 155: 1001-7.

7. McNeil HP, Chesterman CN, Krilis SA. Anticardiolipin antibodies and lupus anticoagulants comprise antibody subgroups with different phospholipid binding characteristics. Br J Haematol 1989; 73: 506-13.

8. McNeil HP, Simpson RJ, Chesterman CN, Krilis SA. Anti-phospholipid antibodies are directed against a complex antigen that includes a lipid-binding inhibitor of coagulation: $B_{2}-$ glycoprotein I (apolipoprotein H). Proc Natl Acad Sci USA 1990; 87: 4120-24.

9. Galli $\mathrm{M}$, Comfurius $\mathrm{P}$, Maassen $\mathrm{C}$ et al. Anticardiolipin antibodies (ACA) directed not to cardiolipin but to a plasma protein cofactor. Lancet 1990; 335: 1544-47.

10. Schousboe I. $B_{2}$-glycoprotein I: a plasma inhibitor of the contact activation of the intrinsic blood coagulativil pathway. Blood 1985; 66: 1086-91.

11. Nimpf J, Bevers EM, Bomans PHH et al. Prothrombinase activity of human platelets is inhibited by $B_{2}$-glycoprotein I. Biochim Biophys Acta 1986; 844: 142-49.

12. Tan EM, Cohen AS, Fries JF et al. The 1982 revised criteria for the classification of systemic lupus erythematosus. Arthritis Rheum 1982; 25: 1271-76.

13. Exner T, Rickard KA, Kronenberg $\mathrm{H}$. Sensitive test demonstrating lupus anticoagulant and its behavioural patterns. Br J Haematol 1978; 40: 143-51.

14. Thiagarajan P, Pengo V, Shapiro SS. The use of the dilute Russell's viper venom time 
for the diagnosis of lupus anticoagulants. Blood 1986; 68: 869-75.

15. Rosing J, Tans G, Govers-Riemslag JW et al. The role of phospholipids and factor Va in the prothrombinase complex. J Biol Chem 1980; 255: 274-83.

16. Tans G, Rosing J, Thomassen MCLGD, et al. Comparison of anticoagulant and procoagulant activities of stimulated platelets and platelet-derived microparticles. Blood 1991; 77: 2641-48.

17. Bevers EM, Comfurius $\mathrm{P}$, van Rijn $\mathrm{LLML}$ et al. Generation of prothrombin converting activity and the exposure of phosphatidylserine at the outer surface of platelets. Eur J Biochem 1982; 122: 429-36.

18. Bevers EM, Wiedmer $\mathrm{T}$, Comfurius et al. Defective $\mathrm{Ca}^{2+}$ - induced microvesicle formation and deficient expression of procoagulant activity in erythrocytes from a patient with a bleeding disorder: a study of the red blood cells of Scott Syndrome. Blood 1992; 79: 380-88.

19. Clyne LP. Species specificity of lupus-like anticoagulants. Blut 1986; 53: 287-292.

20. Loeliger A. Prothrombin as co-factor in the circulating anticoagulant in systemic lupus erythematosus? Thromb Diath Haemorrh (Sturtg) 1959; 3: 237-56.

21. Edson JR, Vogt JM, Hasegawa DK. Abnormal prothrombin crossed-immunoelectrophoresis in patients with lupus inhibitors. Blood 1984; 64: 807-13.

22. Fleck RA, Rapaport SI, Rao LVM. Anti-prothrombin antibodies and the lupus anticoagulant. Blood 1988; 72: 512-19.

23. Rivard GE, Schiffman S, Rapaport SI. Cofactor of the 'Lupus Anticoagulant'. Thromb Diath Haemonh (Stuttg.) 1974; 32: 554-63.

24. Hamilton HK, Hattori R, Esmon CT, Sims PJ. Complement proteins C5b-9 induce vesiculation of the endothelial plasma membrane and expose catalytic surface for the assembly of the prothrombinase complex. J Biol Chem 1990; 265: 3809-14.

25. Comfurius P, Senden JMG, Tilly RHJ et al. Loss of membrane phospholipid asymmetry in platelets and red cells may be associated with calcium-induced shedding of plasma membrane and inhibition of aminophospholipid translocase. Biochim Biophys Acta 1990; 1026: 153-160. 


\section{CHAPTER III}

ANTICARDIOLIPIN ANTIBODIES (aCL) DIRECTED NOT TO CARDIOLIPIN BUT TO A PLASMA PROTEIN COFACTOR

Galli $M$, Comfurius P, Maassen C, Hemker HC, de Baets $M H$, van BredaVriesman PJC, Barbui T, Zwaal RFA, Bevers EM.

Lancet 1990; 335: 1544-47 


\section{SUMMARY}

The binding of affinity-purified anticardiolipin (aCL) antibodies to liposomes that contained cardiolipin or phosphatidylserine was investigated. aCL antibodies bound to these liposomes only in the presence of plasma or serum, which indicated a requirement of a plasma component. This component -referred to as aCL-cofactor-was purified; its activity to support aCL antibodies binding to liposomes that contained cardiolipin was not destroyed by heat $\left(10 \mathrm{~min}\right.$ at $\left.90^{\circ} \mathrm{C}\right)$ but was greatly diminished on incubation with trypsin. aCL-cofactor bound liposomes that contained negatively-charged phospholipids but had no affinity for liposomes that contained neutral phospholipid (eg, phosphatidylcholine); this binding was independent of calcium ions. aCL-cofactor was essential for aCL antibodies to bind to liposomes that contained cardiolipin and phosphatidylserine and, when coated on a microtiter plate in the absence of any phospholipid, aCL-cofactor was an apparent antigen for aCL antibodies in an enzyme-linked immunosorbent assay. aCL-cofactor is a single chain polypeptide with an apparent molecular weight of $50 \mathrm{kD}$ (non-reduced), which increases to $70 \mathrm{kD}$ upon reduction, and its properties closely resemble those of $B_{2}$-glycoprotein I (apolipoprotein $\mathrm{H}$ ).

\section{INTRODUCTION}

Anticardiolipin (aCL) and lupus anticoagulant (LA) antibodies are closely related autoantibodies, which may be found in the plasma of patients with Systemic Lupus Erythematosus (SLE), other immunological, neoplastic or infective disorders and apparently normal people with no evidence of underlying disease (1). Some $30 \%$ of people who have these antibodies suffer from arterial or venous thrombosis, thrombocytopenia and recurrent abortions (1).

$\mathrm{aCL}$ and LA antibodies are detected because they react with negativelycharged phospholipids (eg, phosphatidic acid, cardiolipin, phosphatidylserine and phosphatidylinositol) in immunoassays $(2,3)$ and because they prolong phospholipid-dependent clotting tests "in vitro" (4). 
In 1959, Loeliger observed that some plasma samples showed enhanced LA activity when mixed with normal plasma (5); the concept of LA cofactor was introduced and prothrombin was suggested to represent this cofactor (5). In 1965, LA cofactor was localized in the gammaglobulin fraction of both normal and LA positive plasma (6). Rivard et al. (7) showed that LA cofactor was neither prothrombin nor a gammaglobulin but a different molecule with an apparent molecular weight of $200 \mathrm{kD}(7)$ - although it has also been suggested that the cofactor is a laboratory artifact (8). We have purified and characterized a protein, termed aCL-cofactor, which is found in normal plasma and is required for the expression of aCL activity.

\section{MATERIALS AND METHODS}

\section{Patients}

We studied plasma from 2 men found to be seropositive for both aCL and LA antibodies on routine investigation by enzyme-linked immunoassays (ELISAs). One patient, aged 39, had had repeated peripheral thrombosis; the other, aged 51 , had had recurrent thrombosis of cerebral and renal arterioles. Neither had any other feature to suggest a diagnosis of SLE (9).

\section{Purification of anticardiolipin antibodies ( $a C L$ )}

aCL antibodies were purified by a modification of the method described by Pengo et al. (10). Briefly, a mixture of cardiolipin, phosphatidylcholine and cholesterol (molar ratio 2.5:10:4; all from Sigma, St. Louis, MO, USA) in ethanol was dried under a stream of nitrogen. The lipids were resuspended directly in the plasma of the patients to a final cardiolipin concentration of 3 $\mathrm{mg} / \mathrm{ml}$. After incubation at $37^{\circ} \mathrm{C}$ for $1 \mathrm{~h}$, the mixture was diluted $1: 4$ in "tris"-buffered saline (TBS; $0.05 \mathrm{~mol} / \mathrm{l}$ tris, $0.1 \mathrm{~mol} / / \mathrm{NaCl}, \mathrm{pH} 7.4$ ) and centrifuged at $20,000 \times \mathrm{g}$ for $15 \mathrm{~min}$ at $10^{\circ} \mathrm{C}$. The precipitate was washed 3 times with TBS and the liposomal pellet was dissolved in a $2 \%(w / v)$ solution of n-octyl-B-D-glucopyranoside (Sigma) in TBS so that the final concentration of cardiolipin was $3 \mathrm{mg} / \mathrm{ml}$. This mixture was applied to a column of protein A-'Sepharose CL 4B' (Pharmacia Fine, Upssala, Sweden). A.fter extensive 
washing with $2 \%$ octylglucoside to remove the lipids, followed by washing with TBS, the bound $\mathrm{IgG}$ was eluted with $1 \mathrm{~mol} / \mathrm{l}$ acetic acid and the eluates were immediately neutralized by $3 \mathrm{~mol} / \mathrm{l}$ "tris". Fractions that contained IgG were pooled and dialyzed against TBS before they were tested for aCL antibodies content.

\section{ELISA for aCL antibodies}

The assay for aCL antibodies essentially followed the procedure of Loizou et al. (3). Briefly, microtiter plates were coated with cardiolipin ( $30 \mu \mathrm{l}$ of a 50 $\mu \mathrm{g} / \mathrm{ml}$ solution of cardiolipin in ethanol per well). After evaporation of the solvent, followed by washing with PBS, non-specific binding sites were blocked with $10 \%$ bovine serum albumin (Sigma) in PBS for $1 \mathrm{~h}$. Samples that contained aCL antibodies were diluted in $10 \%$ bovine serum in PBS and subsequently applied to the wells. The amount of aCL antibodies bound was assessed by incubation with peroxidase-conjugated goat anti-human IgG. After reaction of peroxidase with chromogenic substrate (tetramethylbenzidine) the optical density at $450 \mathrm{~nm}$ (OD 450) was measured.

\section{Binding experiments}

To determine binding affinity to liposomes, $25 \mu \mathrm{l}$ of aCL antibodies were mixed with $50 \mu \mathrm{l}$ of cardiolipin:phosphatidylcholine:cholesterol (molar ratio 2.5:10:4) liposomes in the presence of $125 \mu$ plasma, TBS or other test materials. Final concentrations were $125 \mu \mathrm{g} / \mathrm{ml}$ and $750 \mu \mathrm{g} / \mathrm{ml}$ for aCL antibodies and cardiolipin, respectively; aCL-cofactor was used at a final concentration of $300 \mu \mathrm{g} / \mathrm{ml}$. After $30 \mathrm{~min}$ incubation at $37^{\circ} \mathrm{C}$ mixtures were centrifuged at $100,000 \mathrm{xg}$ for $15 \mathrm{~min}$ and supernatants were evaluated for the residual aCL activity using the standard ELISA described above. Data are calculated according to the formula:

$$
\mathrm{aCL} \text { bound }=\frac{\mathrm{aCL} \text { total }-\mathrm{aCL} \text { supernatants }}{\mathrm{aCL} \text { total }} \times 100 \%
$$

In some experiments liposomes were used in which cardiolipin was replaced by phosphatidylserine at a molar ratio for phosphatidylserine: phosphatidylcholine:cholesterol of 5:10:4 to correct for the difference in nett charge between cardiolipin and phosphatidylserine or by phosphatidylcholine 
at a molar ratio for phosphatidylcholine:cholesterol of 15:4.

\section{Purification of aCL-cofactor}

aCL-cofactor was purified from plasma by ammonium sulphate precipitation (50-90\% saturation) followed by ion-exchange chromatography on QAESephadex in $50 \mathrm{mmol} / /$ "tris" buffer at $\mathrm{pH}$ 7.4. The column was eluted by a salt-gradient and aCL-cofactor activity was recovered at $100 \mathrm{mmol} / \mathrm{l} \mathrm{NaCl}$. The proteins contaminating the eluted material were denatured by heat treatment $\left(90^{\circ} \mathrm{C}\right.$ for $10 \mathrm{~min}$ ) and removed by centrifugation. The supematant fully retained aCL-cofactor activity and contained only one band as demonstrated by Sodium-dodecylsulphate Polyacrylamide Gel Electrophoresis (SDS-PAGE)

SDS-PAGE was done on a $7.5 \%$ polyacrylamide gel with a $4 \%$ polyacrylamide stacking gel; after electrophoresis the gel was stained with Coomassie Brilliant Blue.

\section{Protein assay}

Protein content of samples was assayed according to Sedmak and Grossberg (9).

\section{RESULTS AND DISCUSSION}

Affinity-purified aCL antibodies from the plasma of both patients reacted strongly with cardiolipin in a lipid-based ELISA.

Binding was little changed by substitution of cardiolipin by phosphatidylserine, whereas binding of affinity-purified aCL antibodies was abolished with phosphatidylcholine-coated wells (data not shown). In direct binding experiments, in which aCL antibodies were incubated with liposomes composed of a mixture of cardiolipin, phosphatidylcholine and cholesterol in TBS, the $100,000 \times \mathrm{g}$ supernatant of this incubation still contained $100 \% \mathrm{aCL}$ activity - which indicated no aCL binding to liposomes. Replacement of TBS by normal plasma reduced aCL activity in the supernatant to less than $5 \%$ (Table) and a similar result was obtained when phosphatidylserine was 
Table L Binding of aCL antibodies to liposomes in the presence of plasma or purified aCL-Cofactor

\begin{tabular}{lccc}
\hline $\begin{array}{l}\text { Composition of } \\
\text { liposomes (molar ratios) }\end{array}$ & $\begin{array}{c}\text { Control } \\
\text { (TBS) }\end{array}$ & Plasma & aCL-Cofactor \\
\hline CL:PC:Chol (2.5:10:4) & $4 \%$ & $96 \%$ & $94 \%$ \\
PS:PC:Chol (5:10:4) & $2 \%$ & $89 \%$ & $93 \%$ \\
PC:Chol (15:4) & $0 \%$ & $0 \%$ & $2 \%$ \\
\end{tabular}

CL: cardiolipin; PC: phosphatydylcholine; Chol: cholesterol; PS: phosphatidylserine

substituted for cardiolipin. No aCL binding was found to liposomes composed of phosphatidylcholine and cholesterol. These findings indicate that a plasma component is involved in the binding of aCL antibodies to liposomes that contain negatively charged phospholipids, as suggested by McNeil et al (12), who also observed that binding of purified antiphospholipid antibodies to immobilised phospholipid required the presence of plasma.

In the standard ELISA for aCL antibodies, different dilutions of the antibody-containing samples are routinely made in $10 \%$ bovine serum in TBS; the same medium is also used during the binding-step of aCL antibodies to the cardiolipin- coated wells of the microtiter plates. We found that bovine serum could be replaced by bovine plasma, human serum or human plasma but not by purified bovine serum albumin. To further investigate the role of plasma in aCL binding to cardiolipin, the standard ELISA was modified. Instead of dilution in $10 \%$ bovine serum, constant amounts of aCL antibodies were mixed with dilutions of normal pooled plasma and applied to the well. Microtiter plates were further processed as described for the standard ELISA. Fig. 1 shows the OD 450 as a function of the plasma concentration: a linear correlation between $\mathrm{OD}$ and plasma concentration is observed from 0 to $0.5 \%$, where a plateau is reached; similar findings were obtained with human serum and bovine plasma or serum. Thus a plasma component is necessary for aCL antibodies binding to immobilized cardiolipin. This plasma component, termed aCL-cofactor, can be detected and measured by this modified ELISA 


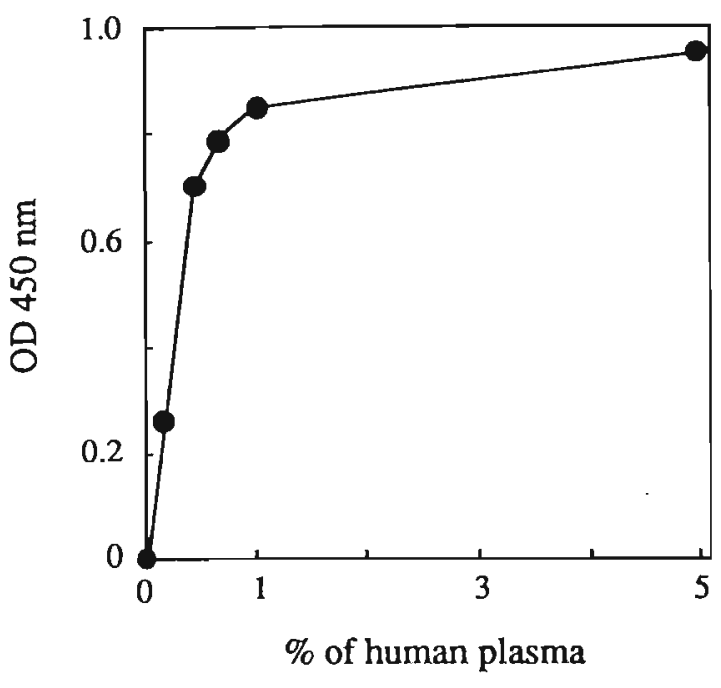

Fig. 1. aCL binding to immobilized cardiolipin at different concentrations of normal plasma.

by comparison with a calibrating curve as shown in Fig. 1.

The final step in the purification of aCL-cofactor involves heat treatment (10 min at $90^{\circ} \mathrm{C}$ ) followed by centrifugation to remove denatured protein material. No loss of aCL-cofactor activity occurred in this step, but when the preparation obtained was incubated with trypsin, aCL-cofactor became inactive. SDS-PAGE showed aCL-cofactor to be a single chain polypeptide with an apparent molecular weight of $50 \mathrm{kD}$ (non-reduced) which increased to $70 \mathrm{kD}$ upon reduction.

The specific activity of the cofactor preparation was 350 times that of crude plasma; if $100 \%$ purity of this preparation was assumed, the plasma concentration of aCL-cofactor would be approximately $0.2 \mathrm{mg} / \mathrm{ml}$.

Purified aCL-cofactor was used to study the interaction of affinity-purified aCL antibodies with liposomes (see Table). aCL-cofactor can be substituted for plasma without loss of binding of aCL antibodies to liposomes that contained negatively-charged phospholipid. Both supernatant and pellet of the binding experiments with purified aCL-cofactor and/or aCL antibodies were analysed by SDS-PAGE as shown in Fig. 2 for samples obtained after incubations with cardiolipin-containing liposomes; similar results are obtained with liposomes that contained phosphatidylserine. No binding of either of the proteins was observed with liposomes without negatively-charged lipids. 


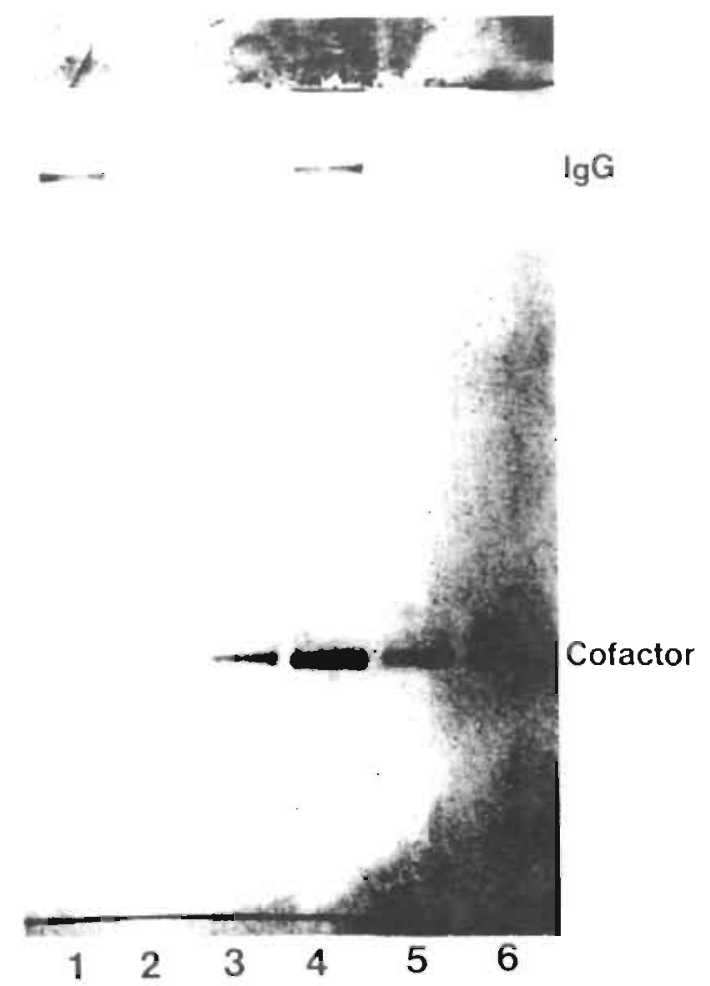

Fig. 2. Binding of $a C L$ antibodies and/or aCL-cofactor to liposomes that contain cardiolipin.

Lanes I and 2: aCL antibodies with liposomes; lanes 3 and 4: $a C L$ antibodies and $a C L$ cofactor with liposomes; lanes 5 and 6: aCL-cofactor with liposomes

Lanes 1,3 and 5 represent proteins remaining in the supernatart; lanes 2, 4 and 6 represent proteins in the liposomal pellet.

Without cofactor, no IgGr was detectable in the $100,000 \times \mathrm{g}$ pellet of the incubations (lanes 1,2); with cofactor, approximately $60-70 \%$ of the $\mathrm{IgG}$ cosediments with the liposomes (lanes 3,4). Incomplete binding of IgG was not due to a limiting amount of aCL-cofactor and the unbound fraction of $\mathrm{IgG}$ in the $100,000 \times \mathrm{g}$ supernatant no longer contained any aCL activity, so the $\mathrm{IgG}$ fraction isolated from the plasma presumably contains antibodies other than $\mathrm{aCL}$ antibodies with non-specific binding to the liposomes used in the affinity purification procedure, or antibodies directed against other lipid-binding proteins in plasma.

Fig. 2 shows that aCL-cofactor also binds to liposomes that contain cardiolipin in the absence of IgG (lanes 5,6). Binding of aCL-cofactor is not dependent on or inhibited by the presence of calcium ions, so it is unlikely that binding is mediated by gamma-carboxyglutamic acid residues on the cofactor. We investigated the direct interaction between aCL-cofactor and affinitypurified aCL antibodies in an ELISA in which the microtiter plates were 
coated with different amounts of cofactor. After coating, a fixed amount of $\mathrm{aCL}$ antibodies or normal $\mathrm{IgG}$ was applied to the wells in the absence of phospholipid. aCL binding was proportional to the amount of aCL-cofactor in the wells (Fig. 3) and no binding was found with normal human IgG. Thus $\mathrm{aCL}$ antibodies of at least these two patients are not directed against cardiolipin but against a protein with a high affinity for negatively-charged phospholipid surface.

It is remarkable that the cofactor is not co-purified during the affinity purification of aCL antibodies via cardiolipin-containing liposomes. Two possible explanations might account for this: aCL antibodies only recognize aCL-cofactor when bound to lipid or adsorbed on a microtiter plate; or aCLcofactor undergoes structural modification upon addition of octylglucoside during aCL antibodies purification. Although aCL-cofactor is present in normal human (and bovine) plasma in concentrations up to $0.2 \mathrm{mg} / \mathrm{ml}$, its identity is still obscure. The heat stability and behaviour on SDS-PAGE (increase in apparent molecular weight upon reduction) suggest the presence of several disulphide bridges. Preliminary experiments with purified coagulation factors indicate that binding of aCL-cofactor to negativelycharged phospholipid surfaces interferes with binding of the prothrombin activating complex factor Xa-factor $\mathrm{Va}$, leading to a diminished rate of

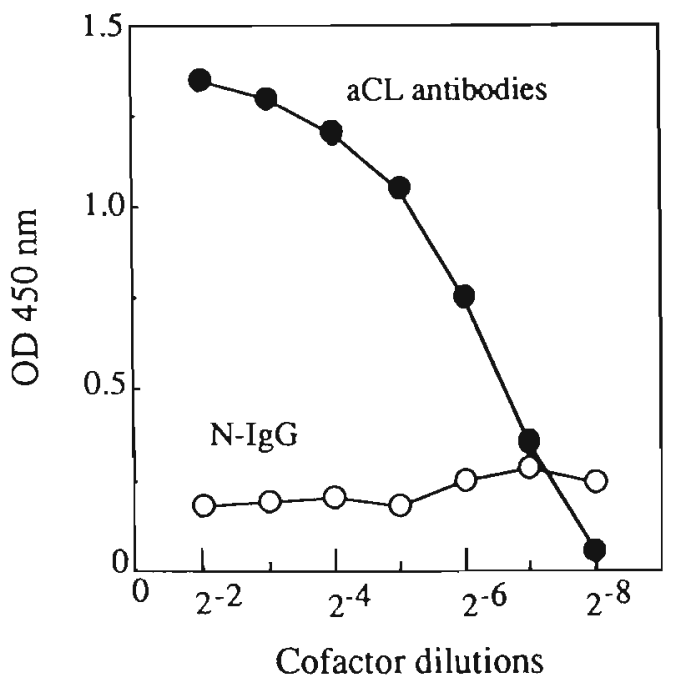

Fig. 3. IgG binding 10 microtiter plates coated with $a C L$-cofactor in the absence of phospholipids.

Concentration of affinity. purified aCL $\operatorname{Ig} G(17 \mu \mathrm{g} / \mathrm{ml})$; normal (non-specific) $I g G$ $(13.3 \mu \mathrm{g} / \mathrm{ml})$; undiluted aCLcofactor was $300 \mu \mathrm{g} / \mathrm{ml}$ 
thrombin formation. Thus aCL antibodies may be directed against a naturally circulating anticoagulant with high affinity towards negatively-charged phospholipid surfaces.

The high purity of the aCL-cofactor allows analysis of aminoacid composition, which is under investigation. However, the properties so far identified (molecular weight $50 \mathrm{kD}$ [non-reduced], $70 \mathrm{kD}$ [reduced with 5\% Bmercaptoethanol]; estimated plasma concentration $200 \mu \mathrm{g} / \mathrm{ml}$; heat stability; calcium-independent binding to anionic phospholipids; support of aCL binding to anionic phospholipids and inhibition of phospholipid-dependent coagulation reactions) are very similar to those of $\mathrm{B}_{2}$-Glycoprotein $I$ (apolipoprotein $\mathrm{H}$ ), the anticoagulant properties of which we have previously described (13).

\section{AKNOWLEDGEMENTS}

M.G. was financially supported by grant EC 87-0225 I 4 from the European Community. We thank Dr. W. Grave for plasma samples from one of the patients and Mrs M. Molenaar-van de Voort for secretarial assistance.

\section{REFERENCES}

1. Lechner K. Lupus anticoagulants and thrombosis. In: Thrombosis and Haemostasis 1987. Verstraete M, Vermylen J, Lijnen HR and Amout J (eds). International Society on Thrombosis and Haemostasis and Leuven University Press, Leuven 1987, pp 525-547.

2. Harris EN, Gharavi AE, Boey ML et al. Anticardiolipin antibodies: detection by radioimmunoassay and association with thrombosis in systemic lupus erythematosus. Lancet 1983; ii: $1211-1214$.

3. Loizou S, McCrea JD, Rudge AC et al. Measurement of anti-cardiolipin antibodies by an enzyme-linked immunosorbent assay: standardizarion and quantitation of results. Clin Exp Immunol 1985; 62: 738-744.

4. Green D, Hougie C, Kazmier FJ et al. Report of the working party on acquired inhibitors of coagulation: studies of "Lupus" Anticoagulant. Thromb Haemostas 1983; 49: $144-146$.

5. Loeliger A. Prothrombin as co-factor of the circulating anticoagulant in Systemic Lupus Erythematosus? Thromb Diath Haemorrh (Stuttg) 1959; 3: 237-256.

6. Yin ET, Gaston LW. Purification and kinetic studies on a circulating anticoagulant in a suspected case of lupus erythematosus. Thromb Diath Haemonth (Stung) 1965; 14: 88-115. 
7. Rivard GE, Schiffman S, Rapaport SI. Cofactor of the "Lupus Anticoagulant". Thromb Diath Haemorrh (Stuttg) 1974; 32: 554-563.

8. Shapiro SS, Thiagarajan P. Lupus anticoagulant. Prog Hemostas Thromb 1982; 6: 263-282.

9. Tan EM, Cohen AS, Fries JF et al. The 1982 revised criteria for the classification of systemic lupus erythematosus. Arthritis Rheum 1982; 25: 1271-76.

10. Pengo $V$, Thiagarajan $P$, Shapiro SS, Heine MJ. Immunolozical specificity and mechanism of action of IgG lupus anticoagulant. Blood 1987; 70: 69-74.

11. Sedmak JJ, Grossberg SE. A rapid, sensitive and versatile assay for protein using coomassie brilliant blue G 250. Analyt Biochem 1977; 79: 544-552.

12 McNeil HP, Chesterman CN, Krilis, SA. Anticardiolipin antibodies and lupus anticoagulants comprise separate antibody subgroups with different phospholipid binding characteristics. Br J Haematol 1989; 73: 506-513

13. Nimpf J, Bevers EM, Bomans PHH et al. Prothrombinase activity of human platelets is inhibited by $B_{2}$-Glycoprotein I. Biochem Biophys Acta 1986; 884: 142-49 
After the publication of Chapter III, Dr Harris and collegues disputed the necessity of a protein "cofactor" for the binding of aCL antibodies to cardiolipin and other negatively-charged phospholipids (Harris EN, Pierangeli $\mathrm{S}$, Barquinero J, Ordi-Ros J. Anticardiolipin antibodies and binding of anionic phospholipids and serum proteins. Lancet 1990; 336: 505-06).

The authors performed binding experiments of serial dilutions of an aCL-positive serum to ELISA plate coated with cardiolipin $(1.5 \mu \mathrm{g} /$ well $)$ or $100 \%$ adult bovine (or human) serum ( $100 \mu \mathrm{g} /$ well). Bovine serum was used as a source of aCL-cofactor. They observed net binding of $\mathrm{aCL}$ antibodies only to wells coated with cardiolipin and not with serum. From these findings they concluded that our report of the necessity of a plasma cofactor for aCL binding to cardiolipin was invalid, otherwise aCL-positive serum would have bound equally well to cardiolipin- and to serum-coated ELISA wells. Harris and coworkers temptatively explained our findings because of phospholipid contamination of the cofactor preparation. Moreover, our choice of liposomes composed of a mixture of cardiolipin/phosphatidylcholine/cholesterol, instead of cardiolipin alone, might have reduced the binding affinity of aCL antibodies to cardiolipin, in this way explaining the lack of binding of affinitypurified aCL antibodies to liposomes containing cardiolipin.

Finally, Harris and collegues evaluated the binding of total IgG containing aCL antibodies to cardiolipin-coated ELISA wells. They observed that the net binding of the patient $\mathrm{IgG}$ was much higher than that of normal $\mathrm{IgG}$ when the IgG's were diluted in $10 \%$ solution of bovine serum instead of buffer alone. According to the authors, this finding, which is clearly in line with our results, was solely due to the better blocking capacity of non specific binding by the $10 \%$ bovine serum solution compared to buffer.

Taken these data together, the authors concluded that $\mathrm{aCL}$ antibodies bind to cardiolipin and not to a plasma protein. 
Here follows our reply (Bevers EM, Galli M. Lancet 1990; 336: 95253) to Dr. Harris and collegues' letter. In the present letter we report about the identification of aCL-cofactor as the plasma protein $\mathrm{B}_{2}$-glycoprotein I:

\section{$B_{2}$-GLYCOPROTEIN I FOR BINDING OF ANTICARDIOLIPIN ANTIBODIES TO CARDIOLIPIN}

\section{Sir,}

In our (June 30, p. 1544) report we demonstrated that in comparison with non-specific IgG there is no net binding of affinity-purified anticardiolipin (aCL) antibodies to cardiolipin-coated ELISA plates or cardiolipin-containing liposomes unless plasma or a protein purified from plasma (aCL-cofactor) is present. We therefore conclude that aCL-cofactor present in normal human (or bovine) plasma (serum) is essential for the binding of aCL antibodies to cardiolipin or in general to negatively charged phospholipid. This contention, which has been confirmed by McNeil et al. (1) and Matsuura et al. (2) is refuted by Dr Harris and collegues (Aug 25, p 505) by a "simple experiment". With the ELISA method, they show that aCLserum binds (almost) equally well to cardiolipin or cardiolipin/adult bovine serum (ABS) coated wells, and does not bind much to wells coated with ABS alone. From this observation they conclude that human or bovine sera are not an absolute requirement for binding of aCL antibodies to cardiolipin. However, we clearly demonstrated (Fig. 1 in our report) that dilutions of plasma or serum down to $1 \%$ can be used before binding of aCL antibodies to cardiolipin is substantially diminished. Since Harris and collegues use serial dilutions of aCL-serum, they introduce sufficient cofactor (present in serum) to support binding of aCL antibodies to cardiolipin.

Moreover, they do not clearly state whether the serial dilutions of aCL-serum were made in phosphate-buffered saline (PBS) or - according to their own recommendations $(3,4)$ - in $10 \%$ ABS/PBS. Furthermore, their argument that coating of the ELISA plate with $100 \%$ ABS in the absence of cardiolipin should also cause binding of aCL antibodies, if our statement were correct, is 


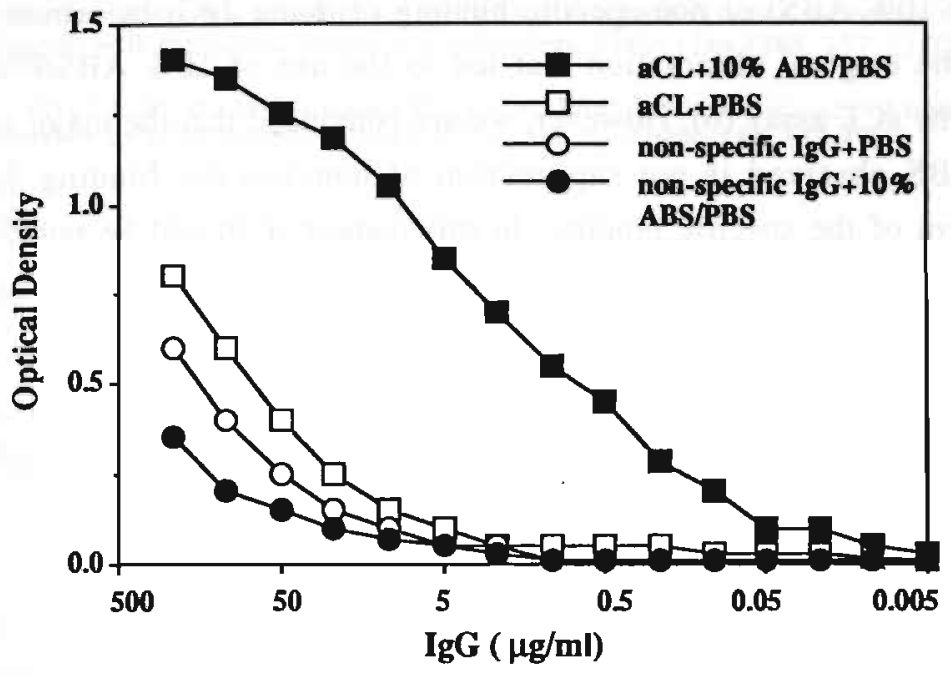

Figure. Comparison of binding of serial dilution (in PBS) of affinity purified aCL antibodies and non-specific IgG to cardiolipin-coated wells.

invalid since adsorption of cofactor will be seriously hampered because of competion by large amounts of other proteins present in serum.

Harris and collegues review poorly other evidence disputing the role of cofactor in binding of aCL antibodies to cardiolipin. They showed net cardiolipin binding of purified IgG from a patient with antiphospholipid syndrome (APS) compared with IgG from a healthy donor, whether these preparations were diluted in $10 \%$ ABS/PBS or PBS alone. Our group obtained similar results, but compared with binding in the presence of $10 \%$ ABS/PBS, the binding of aCL antibodies in PBS alone becomes almost background, despite the slightly increased binding over non-specific IgG in PBS (figure).

Finally, Harris and collegues show that preincubation of IgG-APS with cardiolipin liposomes causes inhibition of binding to cardiolipin-coated ELISA plates. No data are presented showing that this inhibition is not seen with phosphatidylcholine liposomes, which is an essential control since prolonged incubation might cause aspecific binding of IgG to lipid surfaces. Harris et al. mention that net binding of IgG-APS was much higher than IgG donor when $10 \%$ ABS/PBS was used as diluent. The difference is explained by blocking 
(caused by $10 \%$ ABS) of non-specific binding of donor IgG, by which they return to the original observation that led to the use of $10 \% \mathrm{ABS} / \mathrm{PBS}$ as diluent in the aCL assay (6). However, we are convinced that the major effect of $10 \%$ ABS observed is not suppression of non-specific binding but is enhancement of the specific binding. In this respect it should be noted that ABS cannot be substituted by $1 \%$ bovine (or human) serum albumin or gelatin, which would be expected in suppression of non-specific binding.

We have demonstrated concentration-dependent binding of aCL antibodies to cofactor-coated ELISA plates, even in the absence of cardiolipin, and speculated that $\mathrm{aCL}$ antibodies are directed to cofactor rather than cardiolipin. Although, despite the use of sensitive methods, we could not detect any lipid-contamination in the cofactor or aCL preparation, we cannot exclude the possibility that aCL antibodies are directed to a cofactorcardiolipin complex as proposed by McNeil et al. (1) rather than to cofactor alone.

We have now established that the cofactor is $B_{2}$-Glycoprotein I $\left(B_{2^{-}}\right.$ GPI) on the basis of the sequencing of $20 \mathrm{~N}$-terminal aminoacids (kindly done by Dr R.H.M. Ebberink, Applied Biosystems), in accord with McNeil and collegues' data (2). The anticoagulant properties of this protein were investigated in our laboratory in 1986 (5). The interaction of $B_{2}$-GPI with negatively-charged phospholipid vesicles was shown then to alter the physicochemical structure of these vesicles. It is tempting to speculate that this altered lipid bilayer structure results in exposure of the epitope to aCL antibodies.

\section{REFERENCES}

1. McNeil HP, Simpson RJ, Chesterman CN, Krilis SA. Antiphospholipid antibodies are directed against a complex antigen that includes a lipid-binding inhibitor of coagulation: $B_{2}$ glycoprotein I (apolipoprotein H). Ptoc Natl Acad Sci USA 1990; 87: 4120-24.

2. Matsuura E, Igarashi $\mathrm{Y}$, Fujimoto $\mathrm{M}$ et al. Anticardiolipin cofactor(s) and differential diagnosis of autoimmune disease. Lancet 1990; 336: 177-78.

3. Harris NE. Antiphospholipid antibodies. Br J Haematol 1990; 74: 1-9.

4. Harris NE, Gharavi AE, Wasley GD, Hughes GRV. Use of an enzyme-linked 
immunosortent assay and of inhibition studies to distinguish between antibodies to cardiolipin from parients with syphilis or autoimmune disonders. J Infect Dis 1988; 157: 23-31.

5. Nimpf J, Bevers EM, Bomans PHH et al. Prothrombinase activity of human platelets is inhibited by $B_{2}$-Glycoprotein I. Biochim Biophys Acta 1986; 884: 142-49. 


$$
\text { . }
$$




\section{CHAPTER IV}

ANTICOAGULANT ACTIVITY OF $B_{2}$-GLYCOPROTEIN I IS POTENTIATED BY A DISTINCT SUBGROUP OF ANTICARDIOLIPIN ANTIBODIES

Galli $M$, Comfurius $P$, Barbui T, Zwaal RFA, Bevers EM.

Thromb Haemostas 1992; 68: 297-300 


\section{SUMMARY}

Plasmas of 16 patients positive for both $\mathrm{IgG}$ anticardiolipin (aCL) and lupus anticoagulant (LA) antibodies were subjected to adsorption with liposomes containing cardiolipin. In 5 of these plasmas both the anticardiolipin and the anticoagulant activities were co-sedimented with the liposomes in a dose-dependent manner, whereas in the remaining cases only anticardiolipin activity could be removed by the liposomes, leaving the anticoagulant activity (LA) in the supernatant plasma. aCL antibodies purified from the first 5 plasmas was defined as aCL-type A, while the term aCL-type B was used for antibodies in the other 11 plasmas, from which 2 were selected for this study.

Prolongation of the dRVVT was produced by affinity-purified aCL-type A antibodies in plasma of human as well as animal (bovine, rat and goat) origin. aCL-type B antibodies were found to be devoid of anticoagulant activity, while the corresponding supernatants containing LA IgG produced prolongation of the dRVVT only in human plasma.

These anticoagulant activities of aCL-type $A$ and of LA IgG's were subsequently evaluated in human plasma depleted of $B_{2}$-glycoprotein I $\left(B_{2}\right.$ GPI), a protein which was previously shown to be essential in the binding of $\mathrm{aCL}$ antibodies to anionic phospholipids. Prolongation of the $\mathrm{dRVVT}$ by $\mathrm{aCL}-$ type $A$ antibodies was abolished using $B_{2}$-GPI deficient plasma, but could be restored upon addition of $B_{2}$-GPI. In contrast, LA IgG caused prolongation of the dRVVT irrespective of the presence or absence of $B_{2}$-GPI.

Since $B_{2}$-GPI binds to negatively-charged phospholipids and impedes the conversion of prothrombin by the factor $\mathrm{Xa} / \mathrm{Va}$ enzyme complex (Nimpf et al. Biochim Biophys Acta 1986; 884: 142-49), comparison was made of the effect of aCL-type A and aCL-type B antibodies on the rate of thrombin formation in the presence and absence of $B_{2}$-GPI. This was measured in a system containing highly purified coagulation factors $\mathrm{Xa}, \mathrm{Va}$ and prothrombin and lipid vesicles composed of 20 mole \% phosphatidylserine and 80 mole\% phosphatidylcholine. No inhibition on the rate of thrombin formation was observed with both types of aCL antibodies when either $B_{2}$-GPI or the lipid vesicles were omitted. Addition of $B_{2}$-GPI to the prothrombinase assay in the presence of the lipid vesicles caused a time-dependent inhibition which was not 
affected by the presence of aCL-type B or non-specific IgG. In contrast, the presence of aCL-type $\mathrm{A}$ antibodies dramatically increased the anticoagulant effect of $B_{2}$-GPI. These data indicate that the anticoagulant activity of aCLtype $A$ antibodies in plasma is mediated by $B_{2}$-GPI.

\section{INTRODUCTION}

The so-called "antiphospholipid antibodies" represent a wide group of autoantibodies, which include anticardiolipin (aCL) and lupus anticoagulant (LA) antibodies. $\mathrm{aCL}$ antibodies are recognized by their ability to react with anionic phospholipids in solid-phase immunoassays (1), whereas LA antibodies prolong the clotting time of phospholipid-dependent coagulation reactions (2). aCL and LA antibodies have long been considered to be closely related or even identical autoantibodies. In fact, they occur concurrently in about $75 \%$ of the cases. Moreover, LA antibodies were assumed to inhibit coagulation reactions by competing with coagulation factors for the bindin:; to anionic phospholipid surfaces (3).

In recent years, however, it has been demonstrated that aCL IgG can be separated from LA IgG in more than half of the patients with antiphospholipid antibodies: in these cases aCL antibodies do not express anticoagulant activity, whereas LA antibodies do not bind to anionic phospholipids in the immunoassays (4-6). From these studies it became clear that aCL and LA antibodies recognize different epitopes. Moreover, it was also demonstrated that these antibodies require different protein "cofactors" to interact with negatively-charged phospholipids (5-9): aCL antibodies require $B_{2}$. glycoprotein I ( $B_{2}$-GPI) for their binding to anionic lipids (7-9), whereas LA antibodies have been shown to recognize the complex of lipid-bound human prothrombin (6).

However, it has been reported that some aCL antibodies can prolong phospholipid-dependent coagulation reactions $(3,10)$. In agreement with this finding, we have also observed that in some $\mathrm{aCL}$ and LA positive plasmas the removal of aCL antibodies through adsorption to liposomes was accompanied, by a concomitant disappearance of LA activity (6). The aim of the present 
study was to investigate the mechanism by which these aCL antibodies prolong the coagulation time of phospholipid-dependent coagulation reactions. In particular, it was investigated whether $B_{2}$-GPI plays a role in the expression of the anticoagulant properties of aCL antibodies. For these reasons, we studied the anticoagulant activity of $\mathrm{aCL} \operatorname{IgG}$ in the presence and absence of $B_{2}$-GPI both in plasma and in a system using highly purified coagulation factors.

\section{MATERIAL AND METHODS}

\section{Patients:}

This study initially included 16 patients with antiphospholipid antibodies, all of them both aCL and LA positive as determined by solid phase immunoassay (1) and activated partial thromboplastin time (aPTT) and/or kaolin clotting time (2), respectively. In the plasma of 11 patients, aCL antibodies were distinct from LA antibodies, i.e. could be separated by adsorption to liposomes containing anionic phospholipids (Fig. 1, left panel). For the purpose of the present study, 2 patients (patients 6 and 7) were selected from this group of 11 patients. Clinical data of these patients were previously reported (6). The other 5 patients, in which LA antibodies could not be distinguished from aCL antibodies using the above procedure, were 3 males and 2 females, aged 27 to 69 years. Two of them had a clinical history of recurrent deep venous thrombosis, one patient had suffered from a myocardial infarction and 1 other patient suffered from peripheral arterial thrombosis. A mild thrombocytopenia was present in 1 patient $\left(40 \times 10^{9}\right.$ platelets $/ 1)$. None of them fulfilled the criteria for diagnosis of Systemic Lupus Erythematosus (11). All patient plasmas contained polyclonal IgG.

\section{Separation of aCL from $L A$ antibodies}

To investigate whether aCL antibodies could be separated from LA antibodies, the procedure described by Bevers et al. (6) was used. Briefly: liposomes composed of a mixture of cardiolipin, phosphatidylcholine and cholesterol (at 
a molar ratio of 2.5:10:4, respectively) (all from Sigma, St. Louis, MO, USA) were mixed with the plasma of the patients $(3 \mathrm{mg}$ of cardiolipin/ $\mathrm{ml}$ of plasma). After incubation for $30 \mathrm{~min}$ at $37{ }^{\circ} \mathrm{C}$, the liposomes were removed by centrifugation for $10 \mathrm{~min}$ at $12,000 \times \mathrm{g}$. The liposome-free supernatants were analyzed for $\mathrm{aCL}$ and LA activity. aCL activity was determined by solid phase immunoassay according to Loizou et al (1). LA activity was measured by aPTT (3), using a mixture of 1 vol supernatant and 2 vol normal pooled plasma. The diluted Russell viper venom time (dRVVT) was measured after addition of purified IgG to normal human and animal plasmas as described by Thiagarajan et al. (12).

\section{Affinity-purification of aCL antibodies}

aCL antibodies were affinity purified from patients' plasma as previously described (8). All aCL antibody preparations were adjusted to the same titer in the solid phase immunoassy (1) prior to evaluation in coagulation assays.

\section{Purification of total $\mathrm{Ig} G$}

Total IgG, devoid of aCL activity, was isolated from the supernatant of the plasmas of patient 6 and 7 after liposomal adsorption using protein-A sepharose CL 4B affinity-chromatography (Pharmacia Fine, Uppsala, Sweden). These preparations are referred to as LA IgG's. Protein A affinity chromatography was also used to obtain total non-specific IgG from normal plasma.

Human $\beta_{2}$-GPI deficient plasma

Human $B_{2}$-GPI deficient plasma, prepared as described by Oosting et al. (13) was a kind gift of drs. P. G. de Groot, J.D. Oosting and R.H.W.M. Derksen (Utrecht, The Netherlands).

\section{Preparation of $\beta_{2}-G P I$}

$B_{2}$-GPI was purified from human plasma according to Poltz (14).

\section{Prothrombinase activity}

To evaluate the effect of $B_{2}$-GPI alone or in combination with aCL antibodies 
on the prothrombinase activity, highiy purified coagulation factors of bovine origin were used. Coagulation factors $\mathrm{Xa}, \mathrm{Va}$ and prothrombin were purified from bovine plasma according to Rosing et al. (15). The lipid source in this assay were unilamellar vesicles, prepared by sonication in "Tris" buffered saline (TBS: $0.05 \mathrm{~mol} / / \mathrm{tris}, 0.1 \mathrm{~mol} / \mathrm{l} \mathrm{NaCl}, \mathrm{pH} 7.4$ ) of a mixture composed of 20 mole \% phosphatidylserine and 80 mole \% phosphatidylcholine at a total phospholipid concentration of $1 \mathrm{mmol} / \mathrm{l}$. Prothrombinase activity was measured essentially according to Nimpf et al. (16) with minor modifications. Briefly, the prothrombinase assay was performed in TBS containing 0.5 $\mathrm{mg} / \mathrm{ml}$ human serum albumin (Sigma, St. Louis, MO, USA) as follows: $115 \mu \mathrm{l}$ lipid vesicles (diluted to $0.43 \mu \mathrm{mol} / \mathrm{l}$ in TBS containing $0.5 \mathrm{mg} / \mathrm{ml}$ albumin) were mixed with $25 \mu 1$ non-specific- or patients' immunoglobulins (final concentration 6-100 $\mu \mathrm{g} / \mathrm{ml})$ in the presence or absence of $50 \mu \mathrm{l} \mathrm{B}_{2}$-GPI (1.4 $\mathrm{mg} / \mathrm{ml})$. After variable incubation times $10 \mu \mathrm{CaCl}_{2}(75 \mathrm{mmol} / \mathrm{l})$ and $25 \mu \mathrm{l}$ of a mixture of factors $\mathrm{Xa}$ and $\mathrm{Va}$ (10 and $20 \mathrm{nmol} / \mathrm{h}$, respectively) were added. After $1 \mathrm{~min}$ thrombin formation was started by addition of $25 \mu \mathrm{l}$ prothrombin $(10 \mu \mathrm{mol} / \mathrm{l})$. After another min, $25 \mu \mathrm{l}$ aliquots were transferred from the assay mixture into a cuvette containing $1 \mathrm{ml}$ TBS/EDTA ( $2 \mathrm{mmol} / \mathrm{l}$ EDTA), $\mathrm{pH} 7.4$, to stop the reaction. Thrombin-specific chromogenic substrate S2238 (Kabi, Stockholm, Sweden) was added at a final concentration of $250 \mu \mathrm{mol} / \mathrm{l}$ and from the change in absorbance at $405 \mathrm{~nm}$ the amount of thrombin was calculated using a calibration curve made with known amounts of active site titrated thrombin (15).

\section{RESULTS}

The plasmas of 16 patients with antiphospholipid antibodies (all positive for both aCL and $\mathrm{LA} \mathrm{IgG)} \mathrm{were} \mathrm{incubated} \mathrm{with} \mathrm{cardiolipin-containing}$ liposomes. After sedimentation of the lipids, the supernatant plasmas were evaluated for the residual LA and aCL activities. It was found that in 11 cases aCL antibodies could be separated from LA antibodies (a typical example is shown in Fig. 1, left panel). Further analysis of the separated LA IgG's revealed that these antibodies were directed against the human 
prothrombin/phospholipid complex (cf. ref. 6 and Chapter II of this thesis).

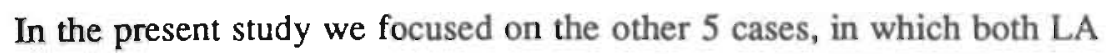
and $\mathrm{aCL}$ antibodies were sedimented together with the liposomes (an example representative for this group is shown in Fig. 1, right panel). aCL antibodies were affinity-purified from the plasmas of these 5 patients using the liposome adsorption procedure described before ( 8 ) and the effect of these antibodies on coagulation reactions was investigated. For comparative reasons, aCL antibodies were affinity-purified in the same way from the plasma of 2 patients belonging to the group of 11 patients. From these 2 patients LA antibody prepaparations devoid of aCL antibodies were obtained as described in Materials and Methods.

The effect of these immunoglobulin preparations was evaluated by dRVVT in the plasma of different mammalian species (Table I). aCL antibodies purified from the 5 patients caused prolongation of the dRVVT in human as well as bovine, rat and goat plasma, although the extent of prolongation by these antibodies seemed to vary somewhat with the plasma source used. In contrast, aCL antibodies purified from the other 2 patients did

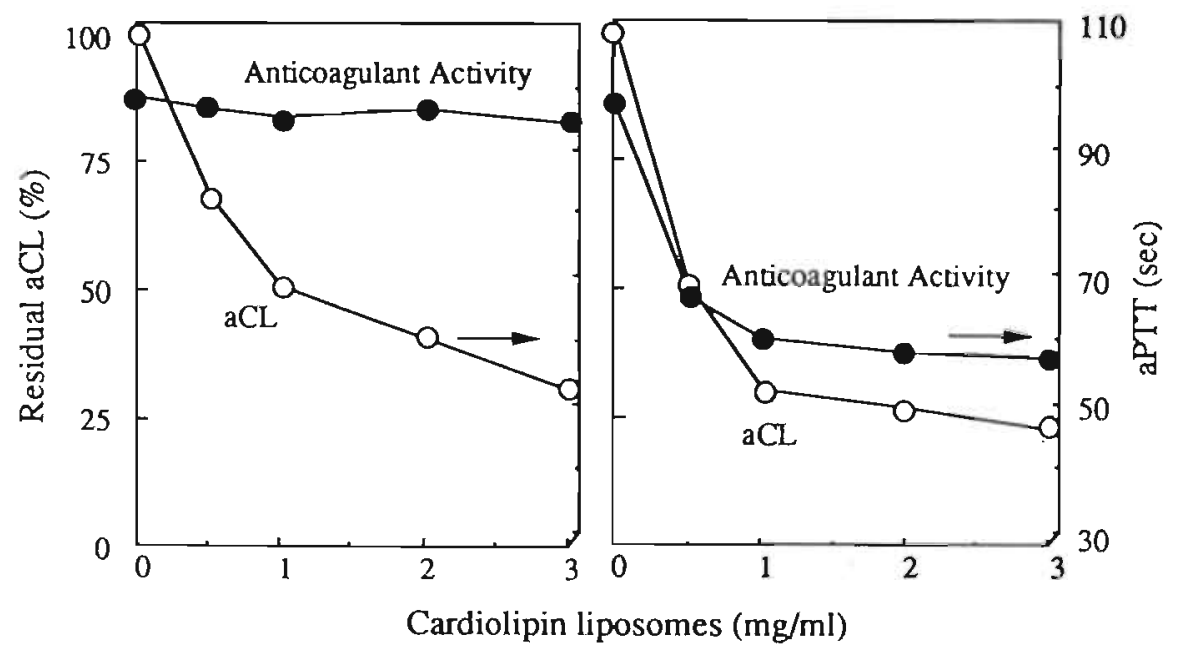

Fig. 1. Effect of adsorption of patient plasma by liposomes containing cardiolipin (or phosphatidylserine). After sedimentation of the liposomes, aCL and the anticoagulant activity are determined in the supernatant plasma by ELSSA and aPTT, respectively. Arrows indicate aPTT clotting time of normal plasma.

Left panel shows a representative example of aCL separable from LA. Right panel shows a representative example of co-adsorption of both $a C L$ and anticoagulant activity (referred to as aCL-type A antibodies). 
Table I. Effect of aCL and LA antibodies on the dRVVT of plasma of different mammalian species.

\begin{tabular}{ccccc}
\hline Sample & $\begin{array}{c}\text { Human } \\
(\mathrm{sec})\end{array}$ & $\begin{array}{c}\text { Bovine } \\
(\mathrm{sec})\end{array}$ & $\begin{array}{c}\text { Rat } \\
(\mathrm{sec})\end{array}$ & $\begin{array}{l}\text { Goat } \\
(\mathrm{sec})\end{array}$ \\
\hline Buffer & 35.9 & 43.5 & 27.0 & 36.0 \\
N-IgG & 36.4 & 42.6 & 27.5 & 34.3 \\
aCL IgG & & & & \\
Pat 1 & 73.1 & 82.9 & 51.2 & 62.9 \\
Pat 2 & 58.4 & 56.7 & 41.0 & 41.9 \\
Pat 3 & 60.7 & 54.6 & 37.7 & 36.3 \\
Pat 4 & 50.8 & 49.9 & 34.7 & 38.4 \\
Pat 5 & 43.5 & 50.0 & 33.4 & 39.5 \\
Pat 6 & 36.8 & 44.7 & 28.6 & 34.9 \\
Pat 7 & 36.6 & 42.5 & 27.9 & 35.2 \\
& & & & \\
LA IgG & & & 29.8 & 34.0 \\
Pat 6 & 91.1 & 45.4 & 29.8 & 33.6 \\
Pat 7 & 52.3 & 44.1 & & \\
\hline
\end{tabular}

not possess anticoagulant activity, while their LA IgG's showed inhibitory effect only in human plasma, as previously reported (6). Thus, aCL antibodies could be separated into 2 groups: aCL-type $A$, which inhibited lipid-dependent clotting reactions and $\mathrm{aCL}$-type $\mathrm{B}$, which did not possess anticoagulant properties. Moreover, aCL-type A antibodies differed from LA antibodies in their mode of action, since they exerted their anticoagulant effect not only in human but also in animal plasmas.

To investigate whether $B_{2}$-GPI was required for the expression of the anticoagulant activity of aCL-type $\mathrm{A}$ antibodies in plasma, the effect of these antibondies on the dRVVT of $B_{2}$-GPI deficient plasma was evaluated. Table II shows that in the absence of $B_{2}$-GPI, aCL-type $A$ antibodies did not express anticoagulant activity. The addition of $0.2 \mathrm{mg} / \mathrm{ml} B_{2}$.GPI to this plasma restored the original degree of prolongation of the dRVVT. On the other hand, LA IgG exerted their anticoagulant effect irrespective of whether $B_{2}$ GPI was present or not. These data indicate that the inhibitory action of aCLtype $A$ antibodies on clotting reactions was dependent on $B_{2}$-GPI. Moreover, 
Table II. Effect of aCL and LA IgG on the dRVVT of normal and $B_{2}$-GPI deficient plasma.

\begin{tabular}{|c|c|c|c|}
\hline \multirow[t]{2}{*}{ Sample } & \multirow{2}{*}{$\begin{array}{c}\text { Control plasma } \\
\qquad(\mathrm{sec})\end{array}$} & \multicolumn{2}{|c|}{ B2-GPI deficient plasma } \\
\hline & & $\begin{array}{c}+ \text { buffer } \\
\text { (sec) }\end{array}$ & $\begin{array}{c}+ \text { B2-GPI } \\
(\mathrm{sec})\end{array}$ \\
\hline $\begin{array}{l}\text { N-IgG } \\
\text { aCL IgG }\end{array}$ & 64.0 & 67.5 & 67.3 \\
\hline Pat 1 & 128.5 & 74.1 & 144.1 \\
\hline Pat 2 & 98.5 & 63.5 & 99.5 \\
\hline Pat 3 & 104.4 & 68.5 & 98.2 \\
\hline Pat 4 & 87.5 & 67.0 & 83.3 \\
\hline Pat 5 & 84.3 & 64.7 & 81.0 \\
\hline LA IgG & & & \\
\hline Pat 6 & 209.7 & 197.3 & 200.3 \\
\hline Pat 7 & 96.6 & 98.0 & 97.3 \\
\hline
\end{tabular}

the prolongation of the dRVVT indicates that these antibodies act at the level of prothrombin conversion by the prothrombinase complex, i.e. factors $\mathrm{Xa}$ and $\mathrm{Va}$ assembled on a phospholipid surface. As shown in Fig. 2, no inhibitory effect of either aCL-type A or aCL-type B antibodies on the prothrombinase activity was observed in the absence of $B_{2}$-GPI. $B_{2}$-GPI alone or in combination with aCL-type $\mathrm{B}$ antibodies (or non-specific $\operatorname{IgG}$ ) showed a timedependent inhibition of the prothrombinase assay. This process was relatively slow, reaching $50 \%$ inhibition in 2 hours. In contrast, aCL-type $\mathrm{A}$ antibodies were able to greatly enhance $B_{2}$-GPI inhibition of the prothrombinase assay: the 5 different aCL-type A IgG preparations showed inhibition ranging from 38 to $87 \%$ within $10 \mathrm{~min}$. For reasons of clarity, the effect of aCL-type A antibodies on the time course of inhibition by $B_{2}$-GPI is shown in Fig. 2 for the patients' aCL which exibited the highest inhibitory effect ( $87 \%$ in $10 \mathrm{~min}$ ). The aCL antibodies from the patient with the lowest inhibitory effect (38\% in $10 \mathrm{~min}$ ) is still appreciably different from the inhibition by $B_{2}$-GP'I alone or in the presence of aCL-type $B$ antibodies (10-12\% in $10 \mathrm{~min}$ ). 


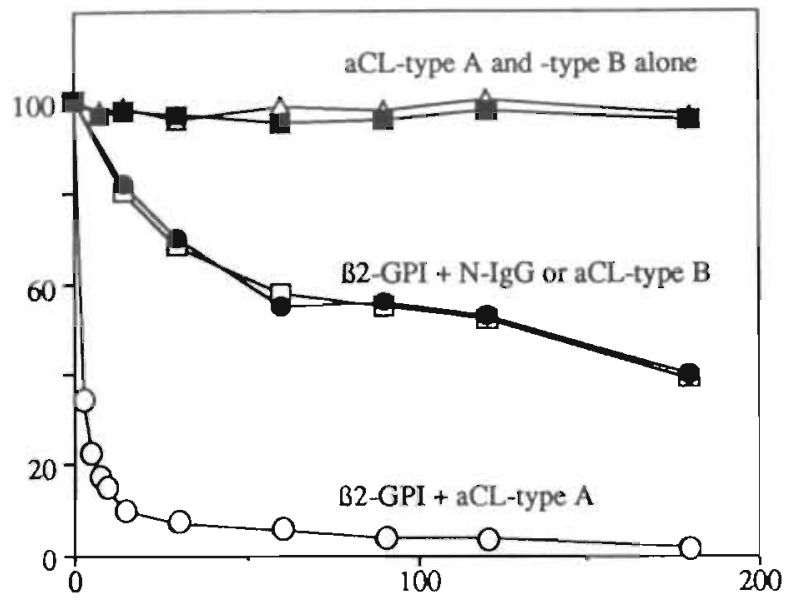

Fig. 2. Time-course of inhibition of the prothrombinasie assay in presence of PSIPC vesicles by: aCL-type A IgG alone; aCL-type $B$ IgGr alone; $\beta_{2} \mathrm{GPI}$ in presence of either nonspecific $\lg G$, or $a C L$ type $A$ or aCL-type $B$ IgG.

Incubation time (min)

\section{DISCUSSION}

In the present study we have demonstrated the existence of 2 types of aCL antibodies, which behave differently in coagulation reactions in plasma. To avoid confusion, we use the term aCL-type $A$ to refer to the aC.L antibodies which prolong phospholipid-dependent coagulation reactions, whereas the term aCL-type B is used for antibodies devoid of anticoagulant activity.

Inhibition of coagulation reactions in plasma by aCL-type A antibodies was strictly dependent on $B_{2}$-GPI, since it was abolished in plasma depleted of this protein. Only one aCL-type A preparation, which showed by far the strongest anticoagulant activity, was still able to produce a slight prolongation of the dRVVT of $B_{2}$-GPI depleted plasma (Table II). This was presumably due to the effect of these potent aCL-type $A$ antibodies on the residual amount of $B_{2}$-GPI (approx. $1 \%$ of the original level) in the depleted plasma. In fact, at a fixed concentration of these antibodies, the prolongation of the dRVVT was dependent on the amount of $B_{2}$-GPI added to the depleted plasma (data not shown).

$B_{2}$-GPI is a plasma protein which binds to several negatively-charged molecules, such as heparin, anionic phospholipids, deoxycholate and DNA (14, 16-18). In 1986, Nimpf et al. (16) have shown that $B_{2}$-GPI, by binding to 
anionic phospholipids, inhibits the conversion of prothrombin by factors Xa and Va. This inhibitory effect occurs at a relatively slow rate and requires at least $60 \mathrm{~min}$ for full expression (16) (see also Fig. 2). We have observed that: aCL-type A, but not type B antibodies are able to enhance in a dose-dependent way the inhibitory action of $B_{2}$-GPI on prothrombin conversion. This effect was produced within a few minutes and could thus explain the anticoagulant activity of aCL-type A antibodies in plasma. It is important to underline that aCL-type A IgG could not inhibit the prothrombinase assay when either the procoagulant lipids or $B_{2}$-GPI were omitted. It should also be emphasized that the anticoagulant activity of aCL-type $A$ antibodies in the prothrombinase assay was independent of the source (bovine or human) of the coagulation factors.

In recent years several authors have demonstrated that most of the $\mathrm{aCL}$ antibodies lack the ability to inhibit coagulation reactions and that in these cases the anticoagulant and anticardiolipin activities reside in 2 different subgroups of antibodies $(4,5)$. These findings were obtained using affinitypurification of aCL antibodies over solid-phase columns of immobilized cardiolipin or phosphatidylserine. It has also been suggested that the previously reported anticoagulant activity of aCL antibodies, that were affinity-purified through adsorption to liposomes $(3,10)$, might be due to copurification of a mixture of phospholipid-binding antibodies (19). The apparent necessity of high aCL antibody concentrations for the expression of the anticoagulant effect further supported this concept (19). Although this possibility cannot be ruled out in general, we could exclude that the different behaviour of aCL-type A and $\mathrm{B}$ antibodies in coagulation reactions was solely due to a difference in aCL titer.

The data presented here extend our studies on the mode of action of antiphospholipid antibodies. Recently, we have demonstrated that LA antibodies, distinct from aCL antibodies, inhibit phospholipid-dependent coagulation reactions because they react with the complex of lipid-bound human prothrombin (6). Thus, 2 acquired inhibitors of blood coagulation aCL-type A and LA antibodies - exist among the antiphospholipid antibodies that hamper phospholipid-dependent coagulation reactions in plasma. Therefore, both of them interfere with the same coagulation tests in vitro. 
However, LA and aCL-type A antibodies can be easily distinguished, since LA antibodies exert their action only in human plasma, whereas aCL-type A antibodies inhibit coagulation reactions irrespective of the plasma source (Table I). Conversely, prolongation of the clotting time by aCL-type A antibodies is strictly $B_{2}$-GPI dependent, while LA antibodies do not require the presence of this plasma protein. aCL-type B antibodies can only be detected by solid phase immunoassay. The reason why this antibody is unable to potentiate the anticoagulant property of $B_{2}$-GPI is presently unknown.

Recently, Oosting and coworkers have demonstrated that depletion of $B_{2}$-GPI by affinity chromatography with polyclonal anti-human $B_{2}$-GPI antibody normalized the dRVVT of 5/6 LA positive plasmas (13). In view of the present findings, anticoagulant activities in these plasmas should originate from aCL-type A antibodies. The one plasma out of these 6 in which the prolonged dRVVT was not corrected upon removal of $B_{2}$-GPI is then likely to contain antibodies directed to lipid-bound human prothrombin (LA), comparable to patients 6 and 7 in Table II.

In view of these findings it now appears that the term "Lupus Anticoagulant" may be a misnomer, which has been used improperly to refer to 2 different inhibitors of blood coagulation: aCL-type A antibodies, which recognize a complex of lipid-bound $B_{2}$-GPI and LA antibodies, which are directed to the complex of lipid-bound human prothrombin (6). In the future a new terminology will probably become necessary to avoid further confusion in the field of "antiphospholipid" research.

In conclusion, our data indicate that the interaction between antiphospholipid $\operatorname{IgG}$ and anionic phospholipids is mediated by plasma proteins and that at least three different types of these antibodies exist (aCLtype A, aCL-type B and LA). At present, little is known about the mode of action of $\operatorname{IgM}$ or IgA isotypes. Moreover, in infectious diseases such as syphilis, aCL antibodies have been described which apparently do not require $B_{2}$-GPI for their binding to anionic phospholipids (9). Antiphospholipid antibodies, therefore, represent a family of rather heterogeneous antibodies and more work is necessary for a better understanding of their mode of action and to elucidate their role - if any - in the pathogenesis of thrombotic complications associated with the antiphospholipid syndrome. 


\section{ACKNOWLEDGEMENT}

We wish to thank Dr R. Wagenvoord for supply of bovine prothrombin. We gratefully acknowledge Drs P.G. de Groot, R.H.W.M. Derksen and J.D. Oosting for their generous gift of $B_{2}$-GPI depleted plasma and for making available their manuscript (13) before publication.

\section{REFERENCES}

1. Loizou S, McCrea JD, Rudge AC et al. Measurement of anticardiolipin antibodies by an enzyme-linked immunosorbent assay: standardization and quantitation of results. Clin Exp Immunol 1985; 62: 738-44.

2. Exner T, Triplett D. Lupus anticoagulants: characteristics, methods of Jaboratory detection and some clinical associations. In: Phospholipid-binding antibodies. Harris EN, Exner T, Hughes GRV, Asherson RA (eds.). CRC Press, Inc. 1991: 141-58.

3. Pengo V, Thiagarajan $P$, Shapiro SS, Heine MJ. Immunological specificity and mechanism of action of IgG lupus anticoagulants. Blood 1987; 70: 69-76.

4. Exner T, Sahman N, Trudinger B. Separation of anticardiolipin antibodies from lupus anticoagulant on a phospholipid polystyrene column. Biochem Biophys Res Commun 1988; 155: $1001-7$.

5. McNeil HP, Chesterman C, Krilis SA. Anticardiolipin antibodies and lupus anticoagulant comprise antibody subgroups with different phospholipid binding characteristics. Br J Haematol 1989; 73 : 506-13.

6. Bevers EM, Galli M, Barbui T et al. Lupus anticoagulant IgG's (LA) are not directed to phospholipids only, but to a complex of lipid-bound human prothrombin. Thromb Haemostas $1991 ; 66: 629-32$.

7. MeNeil HP, Simpson RJ, Chesterman CN, Krilis SA. Anti-phospholipid antibodies are directed against a complex antigen that includes a lipid-binding inhibitor of coagulation: $B_{2}$ glycoprotein I (apolipoprotein H). Proc Natl Acad Sci USA 1990; 87: 4120-24.

8. Galli M, Comfurius P, Maassen C et al. Anticardiolipin antibodies (ACA) directed not to cardiolipin but to a plasma protein cofactor. Lancet 19910; 335: 1544-47.

9. Matsuura E, Igarashi Y, Fujimoto $\mathrm{M}$ et al. Anticardiolipin cofactor(s) and differential diagnosis of autoimmune disease. Lancet 1990;336:177.78.

10. Harris EN, Gharavi AE, Tincani A et al. Affinity purified anti-carcliolipin and anti-DNA antibodies. J Clin Lab Immunol 1985; 17: 155-62.

11. Tan EM, Cohen AS, Fries JF et al. The 1982 revised criteria for the classification! of systemic lupus erythematosus. Arthritis Rheum 1982; 25: 1271-76.

12. Thiagarajan P, Pengo V, Shapiro SS. The use of the dilute Russell viper venom time for the diagnosis of lupus anticoagulants. Blood 1986; 68: 869-74. 
13. Oosting JD, Derksen RHWM, Entjes TI et al. $B_{2}$-glycoprotein I is essential for lupus anticoagulant determination. Thromb Haemostas 1992; 67: 499-502.

14. Polz E. Isolation of a specific lipid binding protein from human serum by affinity chromatography using heparin sepharose. In: Protides of biological fluids. Peeters $\mathrm{H}$ (ed.) Pergamom Press, Oxford 1979; 817-20.

15. Rosing J, Tans G, Govers-Riemslag JW et al. The role of phospholipids and factor Va in the prothrombinase complex. J Biol Chem 1980; 255: 274-83.

16. Nimpf J, Bevers EM, Bomans PH et al. Prothrombinase activity of human platelets is inhibited by $\beta_{2}$-glycoprotein I. Biochim Biophys Acta 1986; 884: 142-49.

17. Kroll J, Larsen JK, Loft $\mathrm{H}$ et al. DNA-binding proteins in Yoshida ascites tumor fluid. Biochim Biophys Acta 1976; 434: 490-501.

18. Schousboe I. Addition of deoxycholate in electroimmunoassay and crossed immunofocusing for quantification of $B_{2}$-glycoprotein I and its subfractions. J Biochem Biophys Meth 1982; 6: 105-14.

19. McNeil HP, Krilis SA. Antiphospholipid antibodies. Aust NZ J Med 1991; 21: 46375. 


\section{CHAPTER V}

EFFECT OF ANTIPHOSPHOLIPID ANTIBODIES ON PROCOAGULANT ACTITY OF ACTIVATED PLATELETS AND PLATELET-DERIVED MICROVESICLES

Galli M, Bevers EM, Comfurius P, Barbui T, Zwaal RFA.

$\mathrm{Br} \mathrm{J}$ Haematol, in press 


\section{SUMMARY}

We have recently described the "in vitro" mechanism of action of anticardiolipin (aCL) and lupus anticoagulant (LA) antibodies in patients with the antiphospholipid syndrome. LA antibodies inhibit coagulation reactions in plasma because they appear to recognize the complex of lipid-bound (human) prothrombin, whereas aCL antibodies require $B_{2}$-glycoprotein $I\left(B_{2}-\mathrm{GPI}\right)$ for binding to anionic phospholipids. aCL antibodies can be divided into two subgroups, according to their behaviour in lipid-coagulation reactions: aCLtype $A$ enhances the anti-coagulant effect of $B_{2}$-GPI, whereas aCL-type $B$ does not.

In the present study we investigated the effect of purified aCL-type A and $\mathrm{B}$ and of LA antibodies on the procoagulant activity of both Ca-ionophore activated platelets and platelet-derived microvesicles in the presence and absence of $B_{2}$-GPI and human prothrombin, using an assay system with highly purified coagulation factors $\mathrm{Xa}, \mathrm{Va}$ and prothrombin from human and bovine origin. In the absence of $\mathrm{B}_{2}-\mathrm{GPI}$ neither type of aCL was able to inhibit the prothrombinase activity of platelets or microvesicles. However, a strong and dose-dipendent inhibition of the prothrombinase activity of both platelets and platelet-derived microvesicles was observed within a few minutes, when aCLtype $A$ antibodies were added in combination with $B_{2}$-GPI. This inhibitory effect was dependent also on the concentration of $B_{2}$-GPI. Conversely, no inhibitory effect of aCL-type B antibodies on platelet- (or microvesicle) prothrombinase activity in the presence of $B_{2}$-GPI could be observed.

LA antibodies were able to inhibit in a dose-dependent way the procoagulant activity of activated platelets and platelet-derived microvesicles. With iwo LA preparations this inhibition was only apparent when human prothrombin was used as substrate, while a third preparation exibited its inhibitory effect both in the presence of human and bovine prothrombin.

These data indicate that in the presence of their respective cofactors $B_{2}$ GPI and prothrombin, aCL and LA antibodies interact with the membrane of platelets and microvesicles in a very similar way as previously observed for their interaction with anionic phospholipid surfaces. 


\section{INTRODUCTION}

Lupus anticoagulant (LA) and anticardiolipin (aCL) antibodies are distinct antibodies, which belong to the group of the so-called antiphospholipid antibodies. Recently, evidence has been obtained that both LA and $\mathrm{aCL}$ antibodies require protein cofactors to react with negatively-charged phospholipids in order to express their immunological reactivities (1-4). LA antibodies inhibit phospholipid-dependent coagulation reactions "in vitro" because they recognize the complex of lipid-bound (human) prothrombin (1), whereas aCL antibodies react with $B_{2}$-Glycoprotein I ( $B_{2}$-GPI) adsorbed onto a phospholipid surface (2-4). Furthermore, aCL antibodies have been divided into two distinct subgroups, according to their anticoagulant behaviour: aCLtype $\mathrm{A}$ antibodies, which prolong phospholipid-dependent coagulation reactions by enhancing the anticoagulant effect of $B_{2}$-GPI and aCL-type $B$ antibodies, that do not promote the anticoagulant activity of $B_{2}$-GPI (5).

It is increasingly appreciated that membranes from activated platelets are an important source of negatively-charged phospholipids (i.c. phosphatidylserine) to provide a catalytic surface for interacting coagulation factors. In resting platelets, phosphatidylserine (PS) is predominantly located in the cytoplasmic leaflet of the plasma membrane. Following activation by different agonists, this asymmetric distribution is lost, leading to exposure of PS at the outer surface, accompanied by shedding of procoagulant microvesicles (6-8). In this sequence of events both platelets and plateletderived microvesicles expose a catalytic surface for the activation of coagulation factor $\mathrm{X}$ and prothrombin by the so-called "tenase" and "prothrombinase" complexes, respectively (9).

The effect of antiphospholipid antibodies on platelet procoagulant activity has been frequently investigated in the last decade. Dahlback et al. demonstrated that a polyclonal IgM with LA activity was able to inhibit the prothrombinase activity expressed by platelets in a systenn with purified coagulation factors (10). This finding was lately confirmed and extended, using a method which allowed to measure platelet prothrombinase activity directly in the plasma of the patients with antiphospholipid antibodies (11). However, other investigators failed to show any interference of 
antiphospholipid antibodies with platelet procoagulant activities, suggesting that platelets might "by-pass" the anticoagulant effect of LA antibodies (12, 13). Thus, it is presently unclear if and to what extent antiphospholipid antibodies are able to inhibit platelet procoagulant activity. Moreover, the putative role which membrane-bound (human) prothrombin and $B_{2}$-GPI may play in this respect is still unknown.

The aim of the present study was to re-evaluate the effect of affinitypurified antiphospholipid antibodies on the prothrombinase activity of both activated platelets and platelet-derived microvesicles using highly purified coagulation factors of human and bovine origin. The different behaviour of LA, aCL-type A and B antibodies was analyzed in the light of their requirement for the cofactors prothrombin and $B_{2}$-GPI, respectively. It is shown that the anticoagulant characteristics of these antibodies in the presence of activated platelets or platelet-derived microvesicles are very similar to those previously observed in the presence of anionic phospholipid vesicles.

\section{PATIENTS, MATERIALS AND METHODS}

\section{Patients}

The study included 7 patients with antiphospholipid antibodies. Clinical data were as follows: 1.Ra., male, age 33, myocardial infarction; 2.Lo., male, age 51, recurrent thrombosis of cerebral and renal arterioles; 3 . Gh., age 39 , recurrent arterial thrombosis of the legs; 4.Ma., male, age 69, recurrent peripheral venous thrombosis; 5.Se., male, age 52, superficial thrombophebitis; 6 . Ra, female, age 32 , recurrent peripheral venous thrombosis; 7. Vi., female, age 54, retroperitoneal hematoma. None of these patients met the revised criteria of the American Rheumatism Association for the diagnosis of Systemic Lupus Erythematosus (14).

All patients were $\operatorname{IgG}$ aCL antibodies positive as determined by ELISA, according to the method described by Loizou et al. (15). A phospholipiddependent inhibitor of coagulation was present in all cases. In fact, the activated partial thromboplastin time (aPTT), kaolin clotting time (KCT) (16) and dilute Russell viper venom time (dRVVT) (17) performed with the plasma 
of the patients were prolonged and not corrected in the 1:1 mixture with normal pooled plasma, according to the criteria proposed by the SSC subcommittee for the standardization of LA (18).

\section{Antibody preparations}

$\underline{\mathrm{aCL}}$ antibodies were purified from patient plasmas by adsorption to cardiolipin containing liposomes and subsequent affinity-chromatography over protein-A sepharose CL-4B (Pharmacia Fin, Upssala, Sweden) as described earlier (2). All aCL preparations were verified to require $B_{2}$-GPI for binding to cardiolipin-coated plates in solid phase immunoassay. For reasons of comparison in coagulation assays, aCL preparations were adjusted to the same titer using the standard immunoassay according to Loizou et al. (15).

aCL antibodies were divided into two groups:

aCL-type A antibodies, isolated from the plasma of patients $1-4$, were found to prolong the dRVVT of both human- and animal (bovine, rat and goat) plasma. The anticoagulant effect of these $\mathrm{aCL}$ antibodies was previously shown to be critically dependent on the presence of $B_{2}$-GPI (5).

- aCL-type B antibodies were purified from the plasma of patients 5-7 and were demonstrated to have no anticoagulant properties.

LA antibodies were found to be present in the total IgG fraction of the plasmas from patients 5-7, obtained by protein A sepharose affinity chromatography. LA antibodies present in total $\mathrm{IgG}$ from patients 5 and 6 were previously characterized to recognize lipid-bound human prothrombin (1), while LA antibodies from patient 7 were not studied before. The inhibitory effect of these antibodies, in contrast to aCL-type A, appeared to be independent of $B_{2}$-GPI.

\section{Prothrombinase assay}

Coagulation factors $\mathrm{Xa}$ and $\mathrm{Va}$ were purified from bovine plasma according to Rosing et al., (19). Prothrombin was purified from both bovine (19) and human (20) plasma. Final concentrations of the various conponents in the prothrombinase assay were: $1 \mathrm{nmol} / \mathrm{l}$ factor $\mathrm{Xa}, 2 \mathrm{nmol} / \mathrm{l}$ factor $\mathrm{Va}, 1 \mu \mathrm{mol} / \mathrm{l}$ prothrombin and $3 \mathrm{mmol} / \mathrm{CaCl}_{2}$. Calcium ionophore-activated platelets were used in the assay at a concentration of $2,000 / \mu \mathrm{I}$ and isolated platelet-derived 
microvesciscles were used at dilutions giving prothrombinase activities similar. to that of $2,000 / \mu 1$ ionophore-activated platelets. In some experiments, phospholipid vesicles $(0.2 \mu \mathrm{mol} / \mathrm{l})$ were used instead of platelets.

To assess the inhibitory effect of $\mathrm{aCL}$, these antibodies were preincubated. with platelets or microvesicles in presence of absence of $B_{2}$-GPI for various time intervals before addition of coagulation factors. In this setup, prothrombinase was initiated by addition of prothrombin.

For determination of the anticoagulant effect of LA antibodies, the assay was slightly modified: total IgG was preincubated for 10 min with human- or bovine prothrombin and activated platelets or microvesicles in the presence of $3 \mathrm{mmol} / 1 \mathrm{CaCl}_{2}$. In this particular case, prothrombinase was initiated upon addition of a mixture of factors Xa and Va.

In both assay systems the amount of thrombin formed at a fixed time interval after initiation of the reaction was measured by transferring $25 \mu$ reaction mixture into a cuvette containing $1 \mathrm{ml}$ EDTA $(2 \mathrm{mmol} / \mathrm{l})$ in "tris" buffered saline $(0.05 \mathrm{~mol} / \mathrm{l}$ tris, $0.1 \mathrm{~mol} / \mathrm{l} \mathrm{NaCl}), \mathrm{pH} 7.4$ to stop the reaction. Thrombin-specific chromogenic substrate S2238 (Kabi, Stockholm, Sweden) was added at a final concentration of $250 \mu \mathrm{mol} / \mathrm{h}$ and from the change in absorbance at $405 \mathrm{~nm}$ the amount of thrombin was calculated using a calibration curve made with known amounts of active site titrated thrombin (19). Inter-assay coefficient of variation of the prothrombinase measurement was less than $5 \%$.

Purification of $\beta_{2}-G P I$

$B_{2}$-GPI was purified from human plasma according to Poltz (21).

\section{Platelets and platelet-derived microvesicles}

Washed human platelets were prepared from blood drawn from healthy volunteers as described elsewhere (22). Platelets were finally resuspended in Hepes buffer ( $136 \mathrm{mmol} / \mathrm{l} \mathrm{NaCl}, 2.7 \mathrm{mmol} / \mathrm{l} \mathrm{KCl}, 2 \mathrm{mmol} / \mathrm{MgCl} 2,10 \mathrm{mmol} / \mathrm{l}$ Hepes, $5 \mathrm{mmol} / \mathrm{l}$ glucose, $0.5 \mathrm{mg} / \mathrm{ml}$ human serum alburain, $\mathrm{pH} 7.5$ ) and activated by incubation for $5 \mathrm{~min}$ at $37{ }^{\circ} \mathrm{C}$ with $1 \mu \mathrm{mol} / \mathrm{l} \mathrm{Ca}$-ionophore A23187 (Calbiochem) in the presence of $3 \mathrm{mmol} / / \mathrm{CaCl}_{2}$. Platelet-derived microvesicles were separated from $\mathrm{Ca}$-ionophore activated platelets by 
differential centrifugation as described by Comfurius et: al. (8).

\section{Unilamellar vesicles}

Unilamellar vesicles were prepared by sonication of mixtures of brainphosphatidylserine (PS) and egg-phosphatidylcholine (PC) at different molar ratio in "tris"-buffered saline according to Rosing et all. (19).

\section{RESULTS}

The time-dependent effect of aCL-type A and B antibodies, obtained from two representative patients (numbers 1 and 5, respectively), on the prothrombinase activity of both activated platelets and platelet-derived microvesicles is shown in Fig. 1. Irrespective of the procoagulant membrane surface, no inhibitory effect of either type of aCL antibodies was observed in the absence of $B_{2}$-GPI. Also, $B_{2}$-GPI either alone or in combination with normal IgG or aCL-type B was not able to inhibit the prothrombinase activity

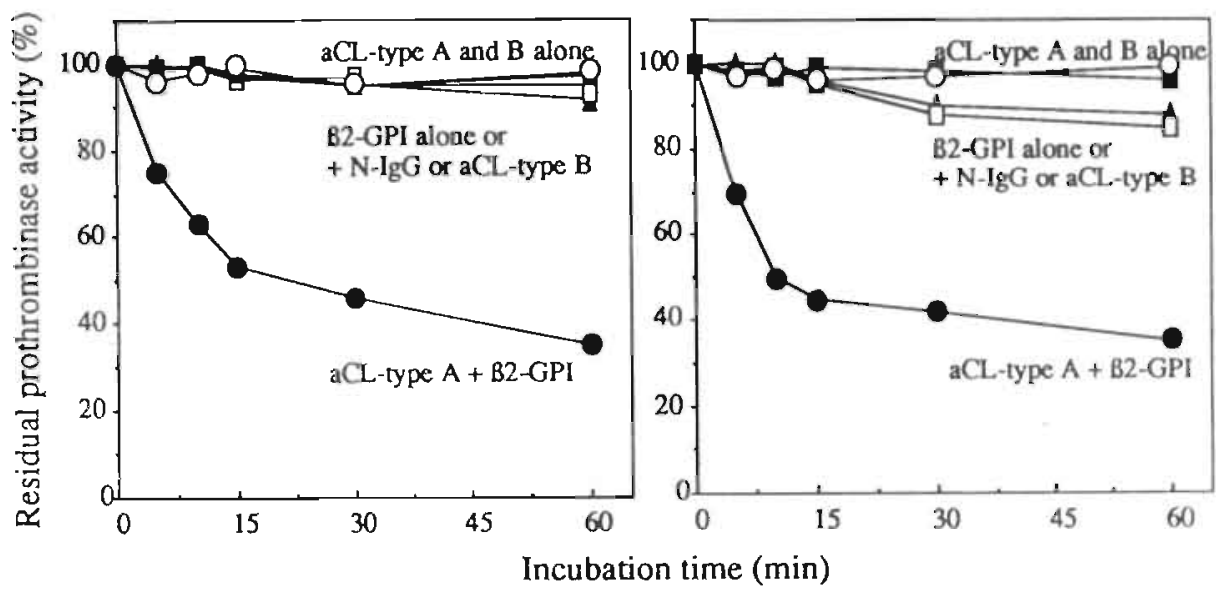

Fig 1. Time-dependent effect of $a C L-t y p e A$ and $B$ antibodies on the prothrombinase activity of acrivased platelets (lefi panel) and platelet-derived microvesicles (right panel) in the presence and absence of $\beta_{2}-G P I(280 \mu \mathrm{g} / \mathrm{ml})$. aCL-type A (patient I) was used at a final concentration of $91 \mu \mathrm{g} / \mathrm{ml}$, whereas aCL-type B (parient 5) was used at $40 \mu \mathrm{g} / \mathrm{ml}$. With non-specific IgG the results were identical to those obtained with aCL-1)pe $B$ (not shown). Prothrombinase activity is expressed as percentage of the activity in the absence of $I g G$ or $\beta_{2}-G P I, \cdots 100 \%$ corresponds to a rate of $186 \mathrm{nM}$ thrombin formed per minute. 


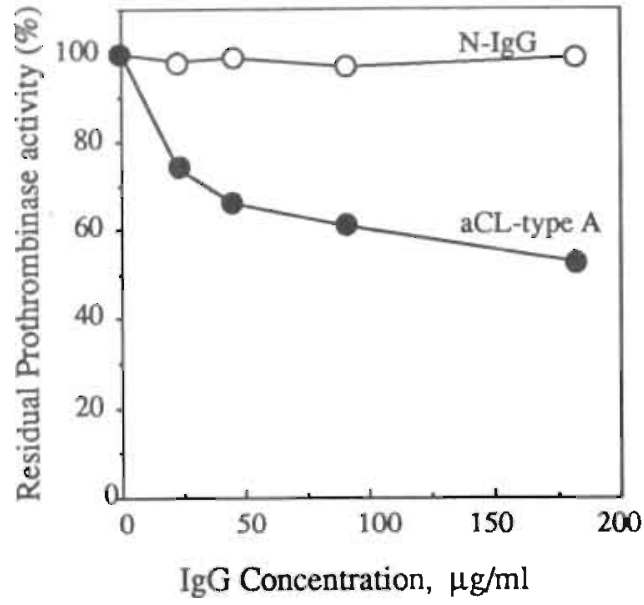

Fig 2. Concentration-dependent inhibition by $a C L-t y p e$ A antibodies from patient 1 on the prothrombinase activity of activated platelets in the presence of $\beta_{2}-G P I$. Antibodies (final concentration indicated on $x$ axis) were incubated with $\beta_{2}-G P I$ $(280 \mu \mathrm{g} / \mathrm{ml})$ and activated platelets for 10 min before addition of coagulation factors $X a, V a$ and prothrombin. $100 \%$ prothrombinase activity corresponds to a rate of 194 nm thrombin formed per minute. Essentially the same results were obtained when platelets were subsitused by microvesicles.

of activated platelets to any appreciable extent within the time course of the experiments, although a minor inhibition was apparent in the presence of platelet-derived microvesicles. On the other hand, a rapid time-dependent inhibition of the prothrombinase activity of both activated platelets and platelet-derived microvesicles was produced by aCL-type $\mathrm{A}$ antibodies together with $B_{2}$-GPI (Fig.1, left and right panel, respectively). This inhibition was dependent on the concentration of both aCL-type $A$ antibodies (Fig. 2) and $B_{2}$-GPI (data not shown). Very similar results were obtained with the aCL-type $A$ antibodies from patients 2, 3 and 4 , and the aCL-type $B$ antibodies from patients 6 and 7 . The effects of each aCL-type $A$ and $B$ antibody preparation in combination with $B_{2}$-GPI on the prothrombinase activity of both activated platelets and platelet-derived microvesicles, after 10 min pre-incubation with the respective platelet membranes, are summarized in Table I.

Fig. 3 shows the concentration-dependent effect of total IgG containing LA antibodies from patient number 5 on the prothrombinase activity towards human prothrombin in the presence of activated platelets or platelet-derived microvesicles. As also shown in Table I, the inhibition observed by the IgG preparation obtained from patient number 5 is representative for the three patients studied. No inhibition of prothrombinase activity was observed in the absence of the procoagulant platelet surface or that of the platelet-derived 
Table I. Inhibition of the prothrombinase activity of activated platelets and platelet-derived microvesicles by aCL- and LA antibodies

\begin{tabular}{llr}
\hline Patient IgG & $\mathrm{mg} / \mathrm{ml}$ & \multicolumn{2}{c}{ Residual Prothrombinase Activity (\%) } \\
activated platelets & platelet microvesicles
\end{tabular}

N-IgG

0.10

100

100

aCL-type A

$\begin{array}{llll}1 & 0.09 & 63 & 50 \\ 2 & 0.08 & 55 & 46 \\ 3 & 0.05 & 66 & 56 \\ 4 & 0.06 & 70 & 60\end{array}$

aCL-type B

$\begin{array}{rrrr}5 & 0.04 & 98 & 97 \\ 6 & 0.03 & 100 & 97 \\ 7 & 0.12 & 99 & 99\end{array}$

LA-IgG

Residual prothrombinase activities are measured after 10 min preincubation with activated plaselets or microvesicles in the presence of either $280 \mu \mathrm{g} / \mathrm{ml} \beta_{2}-G P I$ (for aCL antibodies) or I umolll human prothrombin (for LA antibodies). For measuring LA activity of patients 5.7 total $\lg G$ were used, since the presence of $a C L$-type $B$ does not interfere in the prothrombinase assay. Data represent average of 3 independent experiments; S.D. was less than 5\%.

microvesicles (data not shown). The inhibition was dependent on the concentration of LA antibodies and reached a maximal effect within 7 to 10 min. LA antibodies purified from plasma of patients number 5 and 6 only showed inhibition of the prothrombinase towards membrane-bound human prothrombin, whereas the $\mathrm{IgG}$ preparation obtained from patient number 7 exibited its inhibitory effect irrespective of whether human or bovine prothrombin was the substrate for prothrombinase. Also, in a prothrombinase system containing sonicated PS/PC instead of platelets, the LA antibodies from patient number 7 produced appreciable inhibition in the presence of both human and bovine prothrombin (data not shown), unlike the LA antibodies from patients 5 and 6 , which were only inhibitory when human prothrombin was used as substrate. 


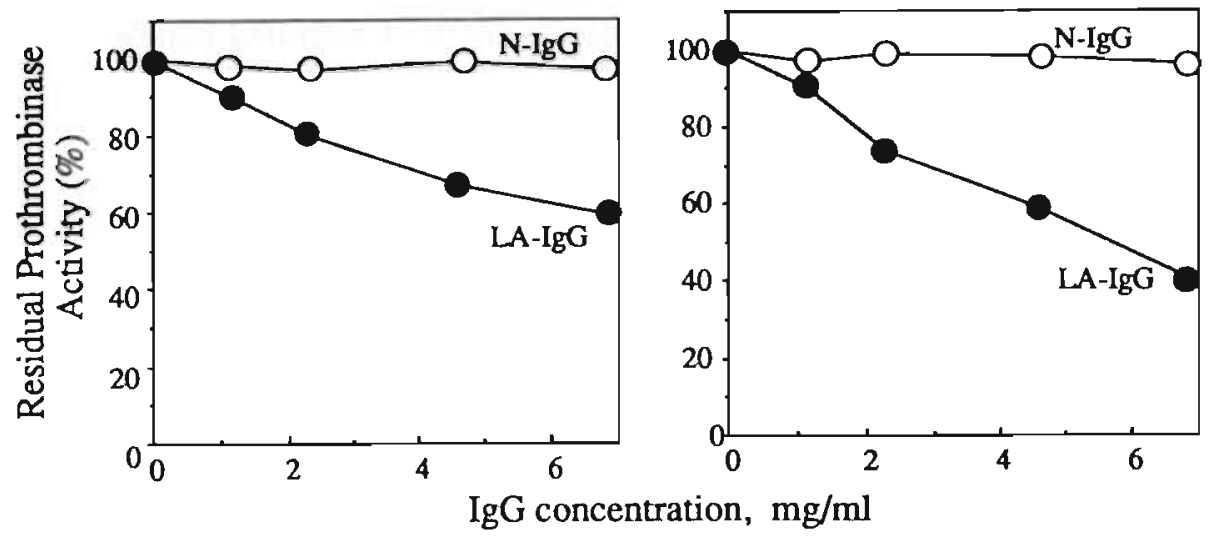

Fig 3. Concentration-dependent inhibitory effect of $L A$ antibodies on the prothrombinase activity of activated platelets (left panel) and platelet-derived microvesicles (right panel) in the presence of human prothrombin. Total $\mathrm{IgG}$ (final concentrations indicated on $x$-axis) from patient 5 were used, since as shown in Table I the presence of aCL-type B in this patient has no anticoagulant effect. $100 \%$ prothrombinase activity corresponds to a rate of $190 \mathrm{nmoll}$ thrombin per minute.

Table II. Inhibition by LA and aCL-type A antibodies on prothrombinase activity of lipid vesicles as a function of the molar ratio PS/PC.

\begin{tabular}{ccc}
\hline PS/PC mol \% & $\begin{array}{c}\text { Residual Prothrombinase Activity (\%) } \\
\text { aCL-type A }\end{array}$ & LA \\
$5 / 95$ & 55 & 80 \\
$10 / 90$ & 42 & 69 \\
$20 / 80$ & 15 & 40 \\
& & \\
\hline
\end{tabular}

Inhibitory effect of aCL was measured using aCL-type $A$ antibodies from patiens $I$ at a final concentration of $91 \mu \mathrm{g} / \mathrm{ml}$ in the presence of $\beta_{2}-G P I(280 \mu \mathrm{g} / \mathrm{ml})$; total IgG from patient 5 were used at a concentration of $6.9 \mathrm{mg} / \mathrm{ml}$ (final concentration) to measure the inhibition by $L A$. Data represent average of 3 independent experiments; SD. was less than $6 \%$

Since platelet-derived microvesicles may expose higher surface concentration of PS than the activated platelets themselves (8), we also studied the inhibitory effect of LA and aCL-type A antibodies on the prothrombinase activity of phospholipid vesicles with variable mole fractions of PS. Table II shows that the inhibition expressed by both antibodies is progressively 
enhanced on increasing the mole fraction of PS of the lipid surface. This may explain why the inhibitory effect of both antibodies on prothrombinase activity is higher in the presence of platelet-derived microvesicles as compared to activated platelets (cf. Table I).

\section{DISCUSSION}

In this study we have demonstrated that LA and aCL-type A, but not aCL-type $B$, antibodies inhibit the prothrombinase activity expressed by activated platelets and platelet-derived microvesicles.

The inhibitory effect of aCL-type A antibodies on platelet prothrombinase activity was strictly dependent on the presence of the plasma cofactor $B_{2}$-GPI as was previously found for prothrombinase activity in the presence of anionic phospholipid vesicles (5). Since aCL-type A antibodies recognize $B_{2}$-GPI bound to anionic phospholipids (2-4), our data strongly suggest that they equally well recognize $B_{2}$-GPI bound to activated platelets or platelet-derived microvesicles.

Conversely, aCL-type B antibodies, although equally able to recognize lipidbound $B_{2}$-GPI, do neither inhibit prothrombinase in the presence of lipids (5) nor in the presence of platelets and platelet-derived microvesicles (this study). The obvious difference in anticoagulant effect between the two types of aCL antibodies may reflect recognition of different epitopes of membrane-bound $B_{2}$-GPI, which are expressed irrespective of whether this cofactor is bound to lipids, platelets or platelet-derived microvesicles.

LA antibodies have recently been shown to recognize prothrombin bound to anionic phospholipid vesicles, leading to inhibition of prothrombinase activity in the presence of lipids (1). The present data show that LA antibodies are also capable to inhibit prothrombinase activity of platelet- and platelet-derived microvesicle membranes. These findings suggest that the mechanism of inhibition of prothrombinase by LA antibodies in the presence of platelets resembles that in the presence of lipids. Also, we recently observed that LA antibodies bind to procoagulant red cell ghost membranes only in the presence of prothrombin and calcium, while aCL antibodies 
require $B_{2}$-GPI to interact with these membranes (see Chapter II of this thesis). In a previous article, we reported that LA antibodies were able to inhibit the phospholipid-dependent coagulation reaction only in human plasma, since they were directed towards the complex of lipid-bound human prothrombin (1). We have now been able to identify an IgG preparation containing LA antibodies (patient number 7), which prolongs coagulation times in lipid-dependent coagulation assays in plasma from different mammalian species (human, bovine, rat and sheep; data not shown) and which inhibits prothrombinase activity in the presence of procoagulant membranes irrespective of whether human or bovine prothrombin is used as a substrate. Although this may indicate that LA antibodies from patient number 7 could recognize lipid-bound prothrombin in a less species-specific way than LA from patients 5 and 6 , it cannot be excluded that the antibodies from patient 7 are directed to lipid-bound factor $\mathrm{Xa}$ and/or Va.

We consistently observed that the rate and extent of inhibition of LA and aCL-type A antibodies on the prothrombinase activity was higher in the presence of platelet-derived microvesicles than in the presence of activated platelets. While we cannot exclude the possibility that this may reflect interaction of the antibodies with differential expression of the $\mathrm{Fc}$ receptors on the membranes of platelets and platelet-derived microvesicles, it seem more likely that this difference is due to the fact that microvesicles expose higher surface concentrations of PS than activated platelets (8). The experiments with vesicles containing increasing concentrations of PS clearly show that the inhibitory effect of LA and aCL-type A antibodies was a function of the molar PS/PC ratio. Moreover, it is known that the extent of binding of $B_{2}$-GPI and prothrombin is directly proportional to the PS density on the procoagulant surface $(23,24)$.

In the present experiments we could hardly detect any inhibition of platelet prothrombinase after $2 \mathrm{~h}$ incubation with $B_{2}$-GPI alone. Only after overnight incubations of $B_{2}$-GPI with activated platelets and platelet-derived microvesicles, appreciable inhibition (some $70 \%$ ) of prothrombinase could be observed. This behaviour is not in agreement with that previously reported by Nimpf et al. (23), who observed $75 \%$ inhibition of Ca-ionophore activated platelet-dependent prothrombinase activity by $B_{2}$-GPI after $60 \mathrm{~min}$. While this 
discrepancy remains unclear, it cannot be excluded that the $B_{2}$-GPI preparation used earlier (ref. 23) may have been contaminated with aCL antibodies, the more so as this preparation was purified from pooled plasma. At that time, the relationship between $B_{2}$-GPI and aCL antibodies was unknown.

In the last years, several authors have studied the effect of antiphospholipid antibodies on the procoagulant activity of platelets both in systems with purified coagulation factors (10) and in plasma (11). These authors concluded that the inhibitory effect was due to a direct binding of the antibodies to the platelet membrane. These findings are only seemingly in contradiction to our data. In fact, Dahlback and coworkers (10) pre-incubated prothrombin with the phospholipid surface before adding the antibodies, in this way allowing the formation of the antigenic target of LA antibodies. In the other case, the assays were performed directly in plasma, where both prothrombin and $B_{2}$-GPI are present (11). Other authors have investigated the binding of antiphospholipid antibodies to platelets. aCL antibodies have been shown to bind to the membrane of activated or freeze-thawed platelets only when serum was used as the source of antibodies (25). More recently, this binding has been demonstrated to be $B_{2}$-GPI dependent (26). These data are clearly in line with our findings. Also, our observations that LA antibodies presumably recognize membrane-bound prothrombin may explain why most authors failed to demonstrate direct binding of LA antibodies to the membrane of activated platelets $(13,27,28)$. However, Chesterman et al. (26) have recently reported preliminary data about the binding properties of LA antibodies, which are in contrast with our observations. These authors described affinity-purified LA antibodies, which apparently could bind to thrombin activated platelets in the absence of plasma components. It cannot be a priori excluded though, that these LA antibodies require a protein cofactor released by activated platelets in order to interact with the platelets membrane. It should be emphasized that these intriguing findings illustrate heterogeneity among antiphospholipid antibodies.

In conclusions, our data indicate that antiphospholipid antibodies bind to the procoagulant membranes of activated platelets and platelet-derived microvesicles via their plasma cofactors. This interaction might have 
physiological implications, expecially with respect to platelet-derived microvesicles, which have been suggested to be present in the plasma of patients with antiphospholipid antibodies (16).

\section{ACKNOWLEDGEMENTS}

We wish to thank drs. J. Rosing and G. Tans for the kind supply of human prothrombin and for helpful suggestions and M. Pelsers for excellent technical assistance. This study was financially supported by a grant from "Nationaal Reuma Fonds" (no. 91CR329/92).

\section{REFERENCES}

1. Bevers EM, Galli M, Barbui $T$ et al. Lupus anticoagulant IgG's (L,A) are not directed to phospholpids only, but to a complex of lipid-bound human prothrombin. Thromb Haemostas $1991 ; 66: 629-32$.

2. McNeil HP, Simpson RJ, Chesterman CN, Krilis SA. Anti-phosphlipid antibodies are directed against a complex antigen that includes a lipid-binding inhibitor of coagulation: $B_{2}$ glycoprotein I (apolipoprotein H). Proc Natl Acad Sci USA 1990; 87: 4120-24.

3. Galli M, Comfurius P, Maassen $\mathrm{C}$ et al. Anticardiolipin antibodies (ACA) directed not to cardiolipin but to a plasma protein cofactor. Lancet 1990; 335: 1544-47.

4. Matsuura E, Igarashi Y, Fujimoto $\mathrm{M}$ et al. Anticardiolipin cofactor(s) and differential diagnosis of autoimmune disease. Lancet 1990; 336: 177-78.

5. Galli $M$, Barbui T, Comfurius $P$ et al. Anticoagulant activity of $B_{2}$-Glycoprotein $I$ is potentiated by a distinct subgroup of anticardiolipin antibodies. Thromb Haemostas 1992; 68: 297-300.

6. Schroit AJ, Zwaal RFA. Transbilayer movement of phospholipids in red cell and platelet mernbranes. Biochim Biophys Acta 1991; 1071: 313-29.

7. Sims P, Wiedmer T, Esmon CT et al. Assembly of the platelet propthrombinase complex is linked to vesiculation of the plasma membrane. Studies in Scott syndrome: an isolated defect in platelet procoagulant activity. J Biol Chem 1989; 264: 17049-57.

8. Comfurius P, Senden JMG, Tilly RHJ et al. I.oss of membrane phospholipid asymmetry in platelets and red cells may be associated with calcium-induced shedding of plasma membrane and inhibition of aminophospholipid traslocase. Biochim Biophys Acta 1990; 1026: $153-60$.

9. Rosing J, van Rijn JLML, Bevers EM et al. The role of activated human platelets in prothrombin and factor X activation. Blood 1985; 319-32. 
10. Dahlback B, Nilsson IM, Frohm B. Inhibition of platelet prothrombinase activity by a lupus anticoagulant. Blood 1983; 62: 218-25.

11. Galli M, Béguin S, Lindhout T, Hemker CH. Inhibition of phospholipid and plateletdependent prothrombinase activity in the plasma of patients with lupus anticoagulants. $\mathrm{Br} \mathrm{J}$ Haematol 1989; 72: 549-55.

12. Firkin BG, Booth P, Hendrix L, Howard MA. Demonstration of a platelet by-pass mechanism in the clotting system using an acquired anticoagulant. Am J Hernatol 1978; 5: 8192.

13. Thiagarajan P, Shapiro SS, De Marco L. Monoclonal immunoglobulin inhibitor with phospholipid specificity. Mechanism of action of a lupus anticoagulant. J Clin Invest 1980; 66: $397-405$.

14. Tan EM, Cohen AS, Fries JF et al. The 1982 revised criteria for the classification of SLE. Arthritis Rheum 1982; 25: 1271-77.

15. Loizou S, McCrea JD, Rudge AC et al. Measurement of anti-cardiolipin antibodies by an enzyme-linked immunosorbent assay (ELISA). Standardization and quantitation of results. Clin Exp Immunol 1985; 62: 738-44.

16. Exner T, Rickard KA, Kronenberg H. Sensitive test demonstrating lupus anticoagulant and its behavioural patterns. Br J Haematol 1978; 40: 143-51.

17. Thiagarajan P, Pengo V, Shapiro SS. The use of the dilute Russell's viper venom time for the diagnosis of lupus anticoagulant. Blood 1986; 68: 869-75.

18. Exner T, Triplett DA, Taberner D, Machin SJ. Guidelines for testing and revised criteria for lupus anticoagulants. Thromb Haemostas 1991; 65: 320-22.

19. Rosing J, Tans G, Govers-Riemslag JWP et al. The role of phospholipids and factor $\mathrm{Va}$ in the prothrombinase complex. J Biol Chem 1980; 255: 274-83.

20. Tans G, Rosing J, Thomassen MCLGD et al. Comparison of anticoagulant and procoagulant activities of stimulated platelets and platelet-derived microparticles. Blood 1991; 77: 2641-8.

21. Polz E. Isolation of a specific lipid binding protein from human serum by affinity chromatography using heparin sepharose. In: protides of biological fluids. Peeters $\mathrm{H}$ (ed.) Pergamon Press, Oxford 1979; 817-20.

22. Bevers EM, Comfurius P, Zwaal RFA. Changes in membrane phospholipid distribution during platelet activation. Biochim Biophys Acta 1983; 736: 57-66.

23. Nimpf J, Bevers EM, Bomans PHH et al. Prothrombinase activity of human platelets is inhibited by $B_{2}$-Glycoprotein I. Biochim Biophys Acta $1986 ; 884: 142-49$.

24. Nelsenstuen GL, Broderius $\mathbf{M}$. Interaction of prothrombin and blood-clotting factor $\mathbf{X}$ with membranes of varying composition. Biochem 1977; 4172-77.

25. Khamashta MA, Harris EN, Gharavi AE et al. Immune mediated mechanism for thrombosis: antiphospholipid antibody binding to platelet membranes. Ann Rheum Dis 1988; 47: 849-54.

26. Chesterman CN, Chong BH, Shi W. Pathogenetic potential of antiphospholipid antibodies: binding to human platelets. Thromb Haemostas 1991; 65: 555 (abstract).

27. Rauch J, Meng Q, Tannenbaum H. Lupus anticoagulant and antiplatelet properties of 
human hybridoma autoantibodies. J Immunol 1987; 139: 2598-604.

28. Hasseiaar P, Derksen RHWM, Blokzijl L, de Groot P. Crossreactivity of antibodies directed against cardiolipin, DNA, endothelial cells and blood platelets. Thromb Haemostas 1990; 63: 169-73. 


\section{CHAPTER VI}

\section{GENERAL DISCUSSION}

Lupus anticoagulant (LA) and anticardiolipin (aCL) antibodies belong to the group of the so-called antiphospholipid antibodies (1). Their presence defines a clinical condition named "antiphospholipid syndrome", which is characterized by arterial and/or venous thrombosis, recurrent abortions and thrombocytopenia (1). The relationship between antiphospholipid antibodies and these haemostatic events has prompted a number of researchers to investigate whether these antibodies may play a pathogenetic role in the development of the thromboembolic complications. Since antiphospholipid antibodies have long been considered to bind to negatively-charged phospholipids, which are an essential constituent of cell membranes, they have been thought to interfere with the functions of blood cells (such as platelets, mononuclear and endothelial cells) (2), producing an imbalance between their pro- and anticoagulant properties (3). However, in spite of a wealth of research, no conclusive demonstration of such a mechanism has been obtained so far. The reasons for these frustrating results are multiple and stem, at least in part, from the heterogeneity of antiphospholipid antibodies and the complexity of their immunological targets (see below). In fact, over the last few years it has become evident that, although frequently concurrent, LA and $\mathrm{aCL}$ antibodies may be separated into two groups of antibodies, which express a different behaviour in coagulation and immunological reactions $(4,5)$.

In this thesis we have tried to elucidate the mechanism of the "in vitro" action of aCL and LA antibodies in the antiphospholipid syndrome, showing that:

1. the interaction of aCL and LA antibodies with negatively-charged phospholipids is mediated by at least 2 plasma proteins, identified as $B_{2}$ Glycoprotein I ( $B_{2}$-GPI) and prothrombin, respectively.

2. at least 3 different types of antiphospholipid antibodies can be 
recognized - aCL-type A, aCL-type B and LA antibodies - which are distinguishable on the basis of their anticoagulant properties in plasma and their immunological reactivity in the immunoassays.

LA and aCL-type A antibodies behave as acquired inhibitors of coagulation. LA antibodies inhibit phospholipid-dependent coagulation tests because they recognize prothrombin bound to a lipid surface, whereas aCL-type A antibodies enhance the anticoagulant properties of $B_{2}$-GPI. Conversely, aCLtype $B$ antibodies are devoid of anticoagulant effect.

Due to its pivotal role in the process of blood coagulation, prothrombin is one of the most studied and best known plasma proteins. In contrast, less information is available for $B_{2}$-GPI, although it has been described for the first time already in 1961 (6). Thus, we will focus here on the biochemical and functional properties of $B_{2}$-GPI.

$B_{2}$-GPI is a single chain polypeptide, with an apparent molecular weight of $50 \mathrm{kD}$ (unreduced), which increases to $70 \mathrm{kD}$ upon reduction. Its amino acid sequence was reported for the first time in 1984 (7). The protein appears rich in prolin and cystein residues and consists largely of repeated units approximately 60 amino acids in length. It contains 11 disulfide bridges (8): this may explain the shift in molecular weight following treatment with a strong reducing agent. More recently, other groups have reinvestigated the aminoacid sequence of $B_{2}$-GPI (8-10), which appears to be highly conservated. In fact, the human and rat polypeptides show more than $80 \%$ homology (9). $B_{2}$-GPI has a plasma concentration of approximately $4 \mu \mathrm{mol} / \mathrm{l}$ $(0.2 \mathrm{mg} / \mathrm{ml})$ and its site of biosynthesis is probably the liver. About $40 \%$ of the protein is associated with different classes of lipoproteins (especially those rich in triglycerides) (11), the remainder circulates free in plasma.

$B_{2}$-GPI is able to bind not only to negatively-charged phospholipids, but also to other anionic molecules, such as DNA, deoxycholate, kaolin and heparin (12-15). It has also been reported that $B_{2}$-GPI binding is able to modify the structural arrangement of anionic phospholipid. This has been observed for phosphatidylcholine/phosphatidylserine vesicles, which form stacked discs (16) and for cardiolipin, which is changed from the lamellar into the hexagonal $\left(\mathrm{H}_{\mathrm{II}}\right)$ phase (17). In this way it is possible to explain the crossreactivity that some antiphospholipid antibodies exhibit, which extends beyond 
anionic phospholipids to include DNA and phospholipids in hexagonal $\left(\mathrm{H}_{\mathrm{II}}\right)$ phase $(18,19)$.

$B_{2}$-GPI has been shown to have several anticoagulant properties "in vitro", among which are the ability to inhibit contact activation of blood coagulation (12), ADP-induced platelet aggregation (21) and platelet- and phospholipid-dependent prothrombinase activity (see below) (16) and the ability to bind and inactivate activated protein $C(20)$. In spite of this "in vitro" behaviour, the physiological role of $B_{2}$-GPI is still unclear. In fact, reduced plasma levels of this protein do not seem to confer an increased risk of thrombosis (22). In patients with antiphospholipid antibodies we have measured either normal or increased levels of $B_{2}$-GPI (23). The clinical relevance of this finding remains to be established, since no correlation was observed between $B_{2}$-GPI levels and aCL or LA activities in plasma or the thromboembolic history of the patients. More recently, similar data have been reported also by Vlachoyannopoulos and coworkers (24) and by Tincani and coworkers (25).

In 1990 the requirement of $B_{2}$-GPI for aCL antibodies to bind to anionic phospholipids was independently reported by our group (chapter III) and two other laboratories $(26,27)$. A main difference, however, existed. between our own and McNeil and coworkers' findings. In fact, we observed that $B_{2}$-GPI itself, adsorbed on an ELISA plate, behaves as a direct antigen for $\mathrm{aCL}$ antibodies. More recently, these data have been confirmed by another group (28). In contrast, McNeil and coworkers reported aCL binding to $B_{2}$ GPI only in the presence of negatively-charged phospholipids, thus suggesting that the antibodies recognize an epitope expressed by the complex of lipidbound $B_{2}$-GPI (26). Several possibilities may account for this discrepancy. In fact, we cannot exclude that aCL antibodies purified from different patients may recognize different epitopes on $B_{2}$-GPI, which in scme: cases may include a phospholipid portion. Another possibility is the lipid contamination of our $B_{2}$-GPI, which is dependent on the purification procedure. We have investigated this possibility, comparing the antigenic activity of $\mathrm{B}_{2}$-GPI before and after lipid extraction by ELISA. One would expect that, if aCL antibodies recognize the complex of lipid-bound $B_{2}-G P I$, the lipid extraction procedure should reduce the antigenic activity of $B_{2}$-GPI. On the contrary, we have 
observed an enhancement of aCL binding to $B_{2}$-GPI coated ELISA wells (unpublished observation). Moreover, we have obtained preliminary evidence that aCL antibodies do not bind to $B_{2}$-GPI in free solution (unpublished data). Taken these observations together, we hypothesize that aCL antibodies recognize a cryptic epitope that is made available upon binding of $\mathrm{B}_{2}$-GPI to a surface, which is not necessarily represented by negatively-charged phospholipids only, but may be polystyrene, PVC (or others) as well (Fig. 1). Data in favour of this hypothesis have been recently put forward by Koike and coworkers, who observed that $B_{2}$-GPI is able to bind to the carbonilic residues of gamma-irradiated polystyrene ELISA plates (29). Moreover, Verrier-Jones demonstrated that $B_{2}$-GPI undergoes a conformational change upon binding to cardiolipin (25). This observation represents an alternative to the above mentioned findings of Nimpf and coworkers (16) and Janoff and coworkers (17). However, one cannot exclude the possibility that at least some aCL antibodies are, actually, directed against $B_{2}$-GPI, as suggested by the recent

INVOLVEMENT OF PROTEINS IN BINDING OF 'ANTIPHOSPHOLIPID ANTIBODIES'
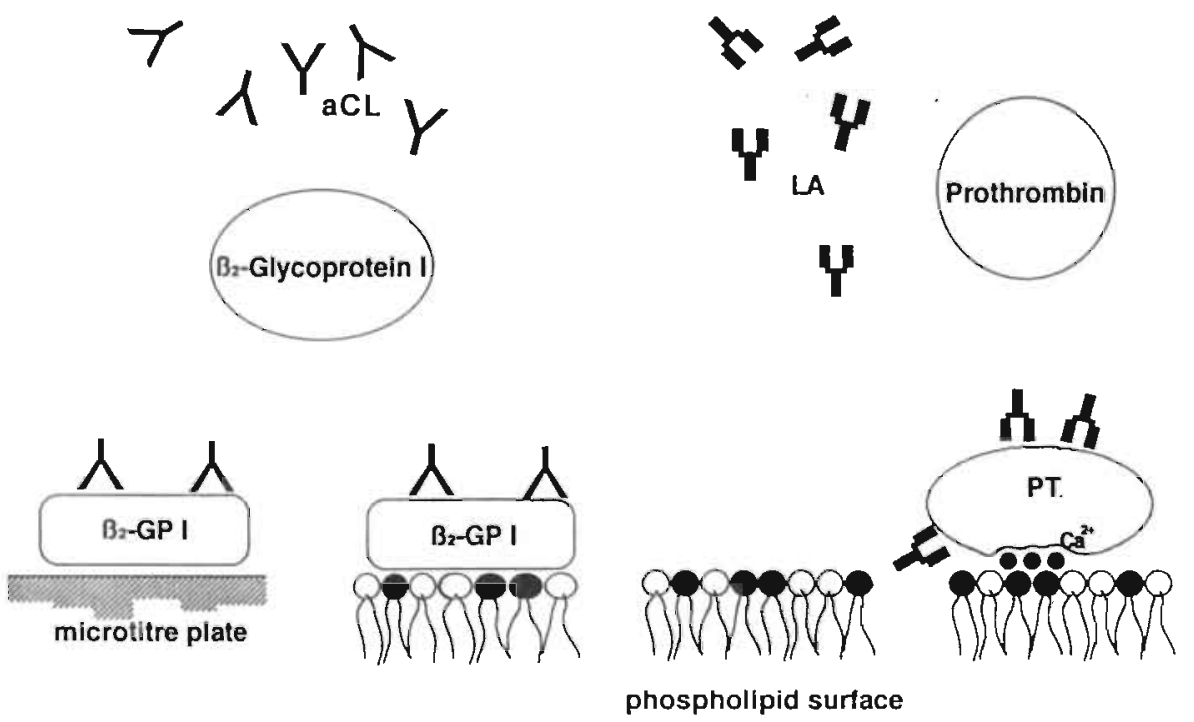

Fig 1. Involvement of proteins in binding of antiphospholipid antibodies: conformational changes of $\beta_{2}$-GPI and prothrombin upon surface binding express neo-epitopes for aCL and $L A$ antibodies, respectively. 
observation by Viard et al. (30), who detected anti $\beta_{2}$-GiPI antibodies in a very high proportion of patients with the antiphospholipid antibodies. Furthermore, monoclonal anti $B_{2}$-GPI antibodies have been shown to express anticoagulant effects similar to those of antiphospholipid antibodies (31). Thus, it is evident that more work will be necessary in the future to characterize the antigenic target of antiphospholipid antibodies.

Since their first presentation, the data conceming the requirement of $B_{2}$-GPI for the interaction between aCL antibodies and their putative antigens have raised a great deal of interest. The importance of this new finding is underlined also by the fact that the role of $B_{2}$-GPI as cofactor of aCL antibodies has been strongly disputed and even rejected by some authorities for a long time $(32,33)$. Anyway, most of the disagreement on this subject has been overcome by now, the leading opinion being in favour of $B_{2}$-GPI. This has been clearly pointed out during an International Workshop devoted to $\beta_{2}$ GPI as aCL-cofactor (25) and also during the "V International Symposium on Antiphospholipid Antibodies" held in S. Antonio on September 9-12, 1992. Among the major topics discussed during the Symposium, in fact, many presentations were dealing with the elucidation of the epitope(s) of aCL antibodies and the immunological and anticoagulant characterization of polyand monoclonal anti- $B_{2}-$ GPI antibodies. This type of antibodies is particularly interesting, since they can, actually, be considered part of the family of antiphospholipid antibodies.

The interaction between aCL antibodies and $B_{2}$-GPI in coagulation tests results, as already mentioned, in recognition of two distinct subtypes: aCLtype $\mathrm{A}$, which are able to prolong the coagulation times of phospholipiddependent coagulation tests in a strictly $B_{2}$-GPI-dependent fashion and aCLtype $B$, which are devoid of anticoagulant activity (Chapter IV). The anticoagulant mechanism of action of aCL-type $A$ antibodies resides on the enhancement of $B_{2}$-GPI binding to the anionic phospholipid surface, which does no longer occur in 30 to $60 \mathrm{~min}$ (16) but is accomplished within 3-5 min. In this way, $B_{2}$-GPI can express its anticoagulant effect also on the coagulation tests currently performed for the detection of antiphospholipid antibodies. Recently, a publication by Oosting and coworkers appeared, showing that the removal of $B_{2}$-GPI from plasma by an anti $B_{2}$-GPI affinity column abolishes 
the anticoagulant activity of plasma containing antiphospholipid antibodies and that the anticoagulant effect is restored by replenishment with $B_{2}$-GPI (34). These data closely resemble ours, although these authors neither elucidated the precise mechanism of action of the antibodies nor identified these antibodies as LA or aCL.

aCL-type A anticoagulant action in plasma can explain the inhibition of the phospholipid-dependent coagulation tests only in a minority of antiphospholipid antibody positive plasmas. In fact, as described in Chapter II, in about $2 / 3$ of the cases LA antibodies could be separated from aCL antibodies. In these cases the effect of LA antibodies in plasma is due to the recognition of the complex of phospholipid-bound human prothrombin. Our findings extend the observation, made by Loeliger already in 1959 (35), on a patient with SLE, whose LA antibodies were associated with hypoprothrombinemia. The author suggested that prothrombin is the "cofactor" necessary for the expression of LA activity in plasma and that a reduced level of prothrombin results from the formation and subsequent scavenging from circulation of the LA antibodies/prothrombin complex on the phospholipid surface. In the following years low levels of prothrombin were repeatedly reported in patients with LA antibodies $(36,37)$. Nevertheless, LA "cofactor" has been variously identified $(38,39)$, and its existence even denied (40).

Fleck and coworkers observed that most LA antibodies were able to crossreact with prothrombin without affecting its enzymatic active site, in this way inducing a variable degree of hypoprothrombinemia (41). Interestingly, these authors failed to demonstrate a direct binding of LA antibodies to purified prothrombin and they could not exclude that phospholipids might participate to the immune complex formation. These data are in good agreement with our findings, which clearly demonstrate the necessity of both a phospholipid surface and prothrombin for the expression of the anticoagulant activity of LA antibodies. Recently, we have performed direct binding experiments which rule out the possibility that the LA effect was due to inhibition of prothrombin binding to the anionic phospholipid (see Chapter II of this thesis). Thus, the other obvious possibility remains to explain the anticoagulant mechanism of L.A antibodies, that is the recognition of the 
complex of lipid-bound prothrombin. In this respect, it is tempting to speculate that LA antibodies might recognize an epitope that prothrombin exposes only after binding to a phospholipid surface, thus simulating the condition already proposed for aCL antibodies and $\mathrm{B}_{2}$-GPI (Fig. 1).

To approach a more physiological condition, the anticoagulant activity of LA and aCL-type A antibodies was evaluated in presence of either activated platelets or platelet-derived microvesicles, which replaced artificial phospholipid vesicles as procoagulant surface (Chapter V). Also under these conditions, prothrombin and $B_{2}$-GPI appeared to be absolutely necessary for the expression of $\mathrm{LA}$ and $\mathrm{aCL}$ anticoagulant effect, respectively. The extent of inhibition was found to depend more on the amount of phosphatidylserine exposed on the outer leaflet of the procoagulant membrane than on the type of surface used, thus confirming a previous observation by Galli and coworkers (42). These findings also give an explanation for the so-called "by-passing" effect of activated or lysed platelets towards LA antibodies in plasma (43).

Our findings indicate that the interaction between antiphospholipid antibodies and anionic phospholipids is mediated by plasma proteins and that at least three different types of antibodies can be recognized. Thus, two acquired inhibitors of blood coagulation - aCL-type A and LA antibodies exist among antiphospholipid antibodies that interfere with phospholipiddependent coagulation reactions. In contrast, aCL-type B antibodies are only detectable by solid phase immunoassay. The reason why this antibody, although $B_{2}$-GPI dependent, is unable to interfere with lipid-dependent coagulation reactions is presently unknown. In the majority of the cases LA and aCL-type A antibodies can easily be distinguished, apparently because most LA antibodies exert their action only in human plasma, whereas aCLtype $A$ antibodies inhibit coagulation reactions in a strictly $B_{2}$-GPI-dependent way irrespective of the plasma source. The species specificity of some LA antibodies, however, is not restricted to human prothrombin only, but might be extended to prothrombin of other species as well.

The existence among antiphospholipid antibodies of two different inhibitors of coagulation, both affecting phospholipid-dependent coagulation tests, may produce difficulties in the interpretation of the published data. In fact, until now the term LA has been indiscriminately used to refer to all cases 
of non-specific, phospholipid-dependent inhibitors of coagulation. For instance, Oosting and coworkers described a LA activity, which actually has the properties of aCL-type A antibodies (34). Similarly, Janoff et al. used the term LA activity to refer to an anticoagulant activity that is neutralized by hexagonal $\left(\mathrm{H}_{\mathrm{II}}\right)$ PE (19). Since the same authors described the ability of $\mathrm{B}_{2}$ GPI to induce hexagonal $\left(\mathrm{H}_{\mathrm{II}}\right)$ phase phospholipids (16), one might argue that they were also dealing with aCL-type A antibodies.

The use of a new nomenclature for antiphospholipid antibodies may be helpful to overcome the existent confusion. In this respect, we here suggest to adopt the term "Anti lipid-bound protein antibodies".

Our observation that $B_{2}$-GPI and prothrombin are involved in the expression of the immunological activity of antiphospholipid antibodies led us to propose a new hypothetical model for the generation of these antibodies in the antiphospholipid syndrome (44). As shown in Fig. 2, a persistent endothelial cell damage and/or platelet activation causes increased expression of procoagulant (read: anionic phospholipid) surfaces.

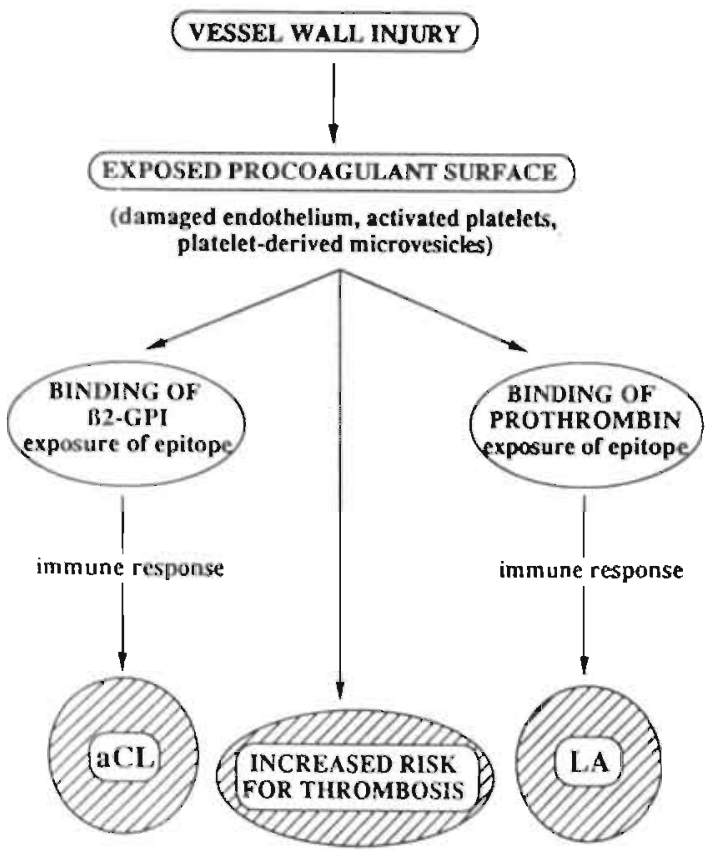

Fig 2. Hypothetical model for the generation of $L A$ and $a C L$ antibodies in the antiphospholipid syndrome. The model alsc explains the frequently observed overlap between $a C L$ and $L A$ antibodies as well as the occurrence of thrombosis in these parients. 
Proteins such as $B_{2}$-GPI and prothrombin, which have a high affinity for anionic phospholipids and are relatively abundant in plasma (about $4 \mu \mathrm{mol} / \mathrm{l}$ and $2.5 \mu \mathrm{mol} / 1$, respectively), may bind to these surfaces, thus exposing cryptic epitopes. The immune response, therefore, could be addressed to the modified proteins rather than to the lipids and should be regarded as a consequence of the exposure of neo-autoantigens instead of being caused by a disregulation of the immune system.

This hypothesis offers an explanation for the frequently observed concurrence of aCL and LA antibodies in the antiphospholipid syndrome and it does not exclude the possibility that the $B_{2}$-GPI-independent binding of some aCL antibodies generally observed in infectious diseases could involve other, as yet unidentified, protein cofactors. Moreover, it also implays a possible explanation for the correlation between antiphospholipid antibodies and thrombosis, since the presence of circulating procoagulant surfaces (such as, for instance, platelet-derived microvesicles) has been suggested to represent a prothrombotic condition (45).

Finally, in view of the involvment of $B_{2}$-GPI and prothrombin, it becomes necessary to re-evaluate the question whether antiphospholipid antibodies play a part - if any - in the pathogensis of thrombosis. Moreover, it is also conceivable that antibodies directed to other protein "cofactors", known to bind to anionic phospholipid surfaces, will be identified. The recent observation by Oosting and coworkers of antibodies that bind the lipidbound/activated protein C complex (46) supports our hypothesis. These and, possibly, other "anti-lipid bound protein antibodies", more than LA and $\mathrm{aCL}$ antibodies, might be responsible for the thromboembolic complications associated with the antiphospholipid syndrome.

\section{REFERENCES}

1. Harris EN, Balestrieri G, Tincani A, Gharavi AE. The immunology of phospholipidbinding antibodies in the antiphospholipid syndrome and related disorders. In: Harris EN, Exner T, Highes GRV, Asherson RA eds. Phospholipid-binding antibodies. CRC Press, Inc 1991: 123-37.

2. Vermylen J, Blockmans D, Spitz B, Deckmin H. Thrombosis and immune disorders. Clin Haematol 1986; 15: 393-412. 
3. Harris EN, Gharavi AE, Hughes GRV. Antiphospholipid antibodies. Clin Rheum Dis 1985; 11: 591-94.

4. Exner T, Sahman N, Trudinger B. Separation of anticardiolipin from lupus anticoagulant on a phospholipid polystyrene column. Biochim Biophys Res Commun 1988; 155: 1001-07.

5. McNeil HP, Chesterman C, Krilis SA. Anticardiolipin antibodies and lupus anticoagulant comprise antibody subgroups with different phospholipid binding characteristics. Br J Haematol 1989; 73: 506-13.

6. Schultze HE, Heide $H$, Haupt $H$. Uber ein bisher unbekanntes niedermoleculares $B_{2}$ globulin des humanserums. Naturwissenschaften 1961; 48: 719-24.

7. Lozier J, Takahashi N, Putnam FW. Complete amino acid sequence of human plasma $B_{2}$-glycoprotein I. Proc Natl Acad Sci USA 1984; 81: 3640-44.

8. Steinkasserer A, Estaller C, Weiss EH, Sim RB. Complete nucleotide and deduced amino acid sequence of human $B_{2}$-glycoprotein I. Biochem J 1991; 277: 387-91.

9. Day JR, O'Hara PJ, Grant FJ et al. Molecular cloning and sequence analysis of the cDNA encoding human apolipoprotein $\mathrm{H}\left(B_{2}\right.$-glycoprotein I). Int J Clin Lab Res 1992; 21 : 256-63.

10. Matsuura E, Igarashi $M$, Igarashi $Y$ et al. Molecular definition of human $B_{2}-$ glycoprotein $I\left(B_{2}-G P I\right)$ by cDNA cloning and inter-species differences of $B_{2}$-GPI in alternation of anticardiolipin binding. Int Immunol 1991; 3: 1217-21.

11. Polz E, Kostner GM. The binding of $\boldsymbol{B}_{2}$-glycoprotein I to human serum lipoproteins. FEBS Lett 1979; 102: 183-86.

12. Schousboe J. $B_{2}$-Glycoprotein I: a plasma inhibitor of contact activation of the intrinsic blood coagulation pathway. Blood 1985; 66: 1085-91.

13. Polz E. Isolation of a specific lipid binding protein from human serum by affinity chromatography using heparin sepharose. In: Protides of biological fluids. Peeters ed. Pergamom Press, Oxford 1979; 817-20.

14. Kroll J, Larsen JK, Loft $\mathrm{H}$ et al. DNA-binding proteins in Yoshida ascites tumor fluid. Biochim Biophys Acta 1976; 434: 490-501.

15. Schousboe I. Addition of deoxycholate in electroimmunoassay and crossed immunofocusing for quantification of $B_{2}$-Glycoprotein I and its subfraction. J Biochem Biophys Meth 1982; 6: 105-14.

16. Nimpf J, Bevers EM, Bomans PHH et al. Prothrombinase activity of human platelets is inhibited by $B_{2}$-Glycoprotein 1. Biochim Biophys Acta 1986: 884: 142-49.

17. Rauch J, Janoff AS. Phospholipid in the hexagonal (II) phase is immunogenic: evidence for immunorecognition of non-bilayer lipid phases in vivo. Proc Natl Acad Sci USA 1990; 87: 4112-14.

18. Rauch J, Meng Q-H, Tannenbaum $\mathrm{H}$. Lupus anticoagulant and antiplatelet properties of human hybridoma autoantibodies. J Immunol 1987; 139: 2598-2604.

19. Rauch J, Tannenbaum H, Janoff AS. Distinguishing plasma lupus anticoagulants from 
anti-factor antibodies using hexagonal (II) phase phospholipids. Thromb Haemostas 1989; 66: 453-58.

20. Canfield WM, Kisiel W. Evidence of normal functional levels of activated protein C inhibitor in combined factor V/VIII deficiency disease. J Clin Invest 1982; 70: 1260-72.

21. Nimpf J, Wurm H, Kostner GM . $B_{2}$-Glycoprotein I (apo $H$ ) inhibits the release reaction of human platelets during ADP-induced aggregation. Atherosclerosis 1987; 63: 109 14.

22. Bancsi LFJMM, van der Linden IK, Bertina RM. $B_{2}$-glycoprotein I and the risk of thrombosis. Thromb Haemostas 1992; 67: 649-53.

23. Galli $M$, Conelazzo $S$, Daldossi $M$, Barbui $T$. Increased levels of $B_{2}$-Glycoprotein I (aca-Cofactor) inpatients with lupus anticoagulant. Thromb Haemostas 1992; 67: 386.

24. Vlachoyiannopoulos PG, Krilis SA, Hunt JE et al. Patients with anticardiolipin antibodies with and without antiphospholipid syndrome: their clinical features and $B_{2}$ glycoprotein-I plasma levels. Eur J Clin Invest 1992; 22: 482-87.

25. Schoenfeld Y, Meroni PL. The beta-2-Glycoprotein I and antiphospholipid antibodies. Clin Exp Rheumatol 1992; 10: 205-09.

26. McNeil HP, Simpson RJ, Chesterman C, Krilis SA. Anti-phospholipid antibodies are directed against a complex antigen that includes a lipid-binding inhibitor of coagulation: $B_{2}$ Glycoprotein I (Apolipoprotein H). Ptoc Natl Acad Sci USA 1990; 87: 4120-24.

27. Matsuura E, Igarashi $Y$, Fujimoto $M$ et al. Anticardiolipin cofactor(s) and differential diagnosis of autoimmune disease. Lancet 1990; 336: 177-78.

28. Arvieux J, Roussel B, Jacob MC, Colomb MG. Measurement of anti-phospholipid antibodies by ELISA using $B_{2}$-Glycoprotein I as an antigen. J Immunol Meth 1991; 143: 223 29.

29. Koike T, Igarashi Y, Nagae $\mathrm{H}$ et al. An altemative ELISA system for detection of anticardiolipin antibodies from patients with antiphospholipid syndrome utilizing solid phase $B_{2}$-glycoprotein I. Fifth International Symposium on Antiphospholipid Antibodies. San Antonio, September 9-12, 1992; (abstract) P3-08.

30. Viard J-P, Amoura Z, Bach J-F. Association of anti- $B_{2}$-Glycoprotein I antibodies with lupus-type circulating anticoagulant and thrombosis in systemic lupus erythematosus. Am J Med 1992; 93: 181-86.

31. Roubey RAS, Pratt CW, Buyon JP, Winfield JB. Lupus anticoagulant activity of autoimmune antiphospholipid antibodies is dependent upon $B_{2}$-Glycoprotein I. J Clin Invest 1992; 90: 1100-04.

32. Harris EN, Pierangeli S, Barquinero J, Ordi-Ros J. Anticardiolipin antibodies and binding of anionic phospholipids and serum protein. Lancet 1990; 336: 505-6.

33. Harris NE, Pierangeli $S$. What is the "true" antigen for antiphospholipid antibodies? Lancet 1990; 336: 1505.

34. Oosting JD, Derksen RHWM, Entjes HT et al. Lupus anticoagulant activity is frequently dependent on the presence of $B_{2}$-Glycoprotein I. Thromb Haemostas 1992; 67; 499 502. 
35. Loeliger A. Prothrombin as co-factor of the circulating anticoagulant in systemic lupus erythematosus? Thromb Diathes Haemorh (Stuttg) 1959; 3: 237-56.

36. Rapapor SI, Ames SB, Duval BJ. A plasma coagulation deficit in systemic lupus erythematosus arising from hypoprothrombinemia combined with antiprothrombinase activity. Blood 1960; 15: 212-20.

37. Bajaj SP, Rapaport SI, Barclay S, Herbst KD. Acquired hypoprothrombinemia due to non-neutralizing antibodies to prothrombin: mechanism and management. Blood 1985; 65: 1538-43.

38. Yin ET, Gaston LW. Purification and kinetic studies on a circulating anticoagulant in a suspected case of lupus erythematosus. Thromb Diathes Haemorrh (Stuttg) 1965; 14: 88- 101.

39. Rivard GE, Schiffman S, Rapaport SI. Cofactor of the "lupus anticoagulant". Thromb Diathes Haemorrh (Stuttg) 1974; 32: 554-63.

40. Exner T, Rickard KA, Kronenberg H. Sensitive test demonstrating lupus anticoagulant and its behavioural patterns. BrJ Haematol 1978; 40: 143-51.

41. Fleck RA, Rapaport SI, Mohan RL. Anti-prothrombin antibodies and the lupus anticoagulant. Blood 1988; 72: 512-19.

42. Galli $\mathrm{M}$, Beguin S, Lindhout $T$, Hemker $\mathrm{CH}$. Inhibition of phospholipid and plateletdependent prothrombinase activity in the plasma of patients with lupus anticoagulants. $\mathrm{Br} \mathrm{J}$ Haematol 1989; 72: 549-55.

43. Firkin BG, Booth P, Hendrix L, Howard MA. Demonstration of a platelet bypass mechanism in the clotting system using an acquired anticoagulant. Am J Hematol 1978; 5: 8192.

44. Bevers EM, Galli M. Cofactors involved in the antiphospholipid syndrome. Lupus 1992; 1: 51-53.

45. Jy W, Horstman LL, Arce M, Ahn YS. Clinical significance of platelet microparticles in autoimmune thrombocytopenia. J Lab Clin Med 1992; 119: 334-45.

46. Oosting JD, Bobbink IWG, Derksen RHWM et al. Prothrombinase complex on endothelial cells and the effect of protein $C$ hereon can be inhibited by antiphospholipid antibodies. V International Symposium on Antiphospholipid Antibodies. San Antonio, September 9-12, 1992. S-17. 


\section{CHAPTER VII}

\section{SUMMARY AND CONCLUSIONS}

Antiphospholipid antibodies represent a wide group of autoantibodies, which includes anticardiolipin (aCL) and lupus anticoagulant (LA) antibodies. aCL antibodies bind to anionic phospholipids in the immunoassays, whereas LA antibodies prolong phospholipid-dependent coagulation tests. They are associated with an increased risk of arterial and/or venous thromboembolism, repeated abortions and thrombocytopenia. The disorder characterized by the presence of these antibodies has been named "Antiphospholipid syndrome". aCL and LA antibodies occur concurrently in $75 \%$ of the cases and have, therefore, been considered closely related or even identical, based on the ability of some affinity-purified aCL antibodies to prolong phospholipiddependent coagulation assays. In recent years, however, it has been demonstrated that in most cases aCL antibodies can be separated from LA antibodies. It has also become clear that the interaction between antiphospholipid antibodies and their putative antigens is far more complex than previously thought and that this interaction requires the participation of protein "cofactors".

\section{$\beta_{2}$-Glycoprotein I: cofactor in the binding of aCL antibodies}

Cofactor involvement in the binding of aCL antibodies to negativelycharged phospholipids is pointed out by the observation that isolated aCL antibodies are able to bind to anionic phospholipid-containing liposomes and to negatively-charged phospholipids coated ELISA plates only in the presence of human (bovine) plasma (serum). The cofactor of aCL antibodies has been purified and characterized as a single chain polypeptide with an apparent molecular weight of $50 \mathrm{kD}$ (non-reduced), which increases to $70 \mathrm{kD}$ upon 
reduction; it has an approximate concentration in plasma of $4 \mu \mathrm{mol} / 1 \mathrm{l}(0.2$ $\mathrm{mg} / \mathrm{ml}$ ); it is heat-stable ( $10 \mathrm{~min}$ at $90{ }^{\circ} \mathrm{C}$ does not reduce its cofactor capacity) and can bind to anionic phospholipids also in the absence of aCL antibodies. This protein has been identified as $B_{2}$-Glycoprotein I ( $B_{2}$-GPI, also referred to as apolipoprotein $\mathrm{H}$ ). Due to its interaction with negatively-charged surfaces, $B_{2}$-GPI has been shown to have several anticoagulant properties "in vitro", among which is the inhibition of the conversion of prothrombin by coagulation factors $\mathrm{Xa} / \mathrm{Va}$ in presence of phosphatidylserine/ phosphatidylcholine (PS/PC) vesicles. The inhibition is maximal at physiological concentrations of the protein and requires prolonged incubation with the phospholipid surface (approximately $60 \mathrm{~min}$ are necessary to express maximal inhibition).

Affinity-purified aCL antibodies have been observed to display 2 different behaviours in coagulation tests: aCL-type A antibodies prolong phospholipid-dependent coagulation reactions in plasma of human as well as animal origin, whereas aCL-type $B$ antibodies are devoid of anticoagulant effect. The inhibitory effect of aCL-type $A$ antibodies is strictly $B_{2}$-GPI dependent, since it is abolished in human plasma depleted of $B_{2}$-GPI and can be restored upon addition of the protein. The anticoagulant mechanism of aCL-type $A$ antibodies is due to the potentiation of the $B_{2}$-GPI effect on the conversion of prothrombin by factors $\mathrm{Xa} / \mathrm{Va}$ on $\mathrm{PS} / \mathrm{PC}$ vesicles $(85 \%$ inhibition within $10 \mathrm{~min}$ ).

It is important to emphasize that only a minority (approximately $1 / 3$ ) of aCL antibodies preparations express anticoagulant activity. In the other cases the inhibitory effect observed in plasma containing antiphospholipid antibodies is due to LA antibodies.

\section{Lipid-bound prothrombin: cofactor in the binding of LA antibodies}

Isolated LA antibodies, separated from aCL antibody preparations, do not bind directly to anionic phospholipids in ELISA assays, neither can be removed from plasma by adsorption to cardiolipin-containing liposomes. 
Moreover, most LA antibodies are able to prolong the coagulation times of phospholipid-dependent coagulation tests (such as aPTT, KCT and dRVVT) only in presence of human plasma; no prolongation of the coagulation times can generally be seen when plasma of bovine, sheep or rat origine is used. The prolongation of the dRVVT also indicates that LA antibodies act at the level of conversion of prothrombin to thrombin by coagulation factors $\mathrm{Xa} / \mathrm{Va}$ on a phospholipid surface. In a system using purified coagulation factors ( $\mathrm{Xa}, \mathrm{Va}$ and prothrombin) of human and bovine origin in the presence and absence of PS/PC vesicles, LA antibodies do not produce appreciable inhibition on the rate of conversion of bovine prothrombin. The inhibitory effect observed in the presence of human prothrombin is independent of the source of factors Xa and $\mathrm{Va}$ and is not found in the absence of lipids. Moreover, LA antibodies bind to anionic phospholipids only when human prothrombin and calcium ions are present. Therefore, these LA antibodies most likely recognize an epitope which becomes exposed upon calcium-mediated binding of human prothrombin to anionic phospholipids. This species-specificity, however, does not seem to be absolute, since we have been able to characterize one preparation of LA antibodies, which can recognize lipid-bound prothrombin of both human and animal origin.

Antiphospholipid antibodies: interaction with platelets and platelet microvesicles

In vivo, the catalytic surface for the formation of the prothrombin (and also factor $\mathrm{X}$ ) activating complex is thought to be provided by the phospholipids of the platelet plasma membrane. However, anionic phospholipids, which are essential to the catalytic properties of the surface, are located in the inner leaflet of the membrane of resting platelets. Dependent on the agonist used, platelet activation leads to a loss of phospholipid asymmetry, resulting in the formation of a procoagulant surface and to shedding of procoagulant microvesicles. Our studies on the effects of LA and aCL-type A and $\mathrm{B}$ antibodies on the procoagulant activity of activated platelets and 
platelet-derived microvesicles have been performed in the presence and absence of $B_{2}$-GPI, using purified coagulation factors of both human and bovine origin. In presence of their respective cofactors, LA antibodies and aCL-type A but not type B antibodies interact with the membrane of activated platelets and platelet-derived microvesicles in a way very similar to that observed for their interaction with PS/PC vesicles. The inhibition of procoagulant activity is proportional to the amount of anionic phospholipid (PS) exposed on the surface.

In conclusion, we have demonstrated that the interaction between antiphospholipid antibodies and anionic phospholipids is mediated by plasma proteins and that at least 3 different types of these antibodies (LA, aCL-type A and $B$ ) can be recognized, which express different immunological and anticoagulant properties. In view of these new findings it will be necessary to re-evaluate the role that antiphospholipid antibodies might play with respect to the pathogenesis of thromboembolic complications frequently occurring in patients who suffer from the antiphospholipid syndrome. 


\section{CAPITOLO VI}

\section{SOMMARIO E CONCLUSIONI}

Gli anticorpi antifosfolipidi rappresentano un ampio gruppo di autoanticorpi, che comprendono gli anticorpi anticardiolipina (aCL) e l' anticoagulante tipo lupus (LA). Gli anticorpi aCL si legano ai fosfolipidi anionici nei tests immunoenzimatici, mentre gli anticorpi LA inibiscono le reazioni di coagulazione fosfolipide-dipendenti. Sono associati ad un rischio elevato di trombosi venosa e/o arteriosa, poliabortività e piastrinopenia e la loro presenza definisce la "Sindrome da anticorpi antifosfolipidi". Gli anticorpi aCL e LA sono stati a lungo considerati strettamente correlati e perfino identici, poiché si osservano contemporaneamente in circa il $75 \%$ dei casi e poiché alcuni anticorpi aCL purificati per affinità sono in grado di prolungare i tests della coagulazione fosfolipide-dipendenti. Recentemente, tuttavia, è stato dimostrato che gli anticorpi aCL possono essere separati dagli anticorpi LA nella maggior parte dei casi. Inoltre, l' interazione tra gli anticorpi antifosfolipidi e i loro bersagli antigenici si è rivelata più complessa di quanto in precedenza ipotizzato, richiedendo la partecipazione di "cofattori" proteici.

$\beta_{2}$-Glicoproteina I: cofattore degli anticorpi aCL

La necessità di un cofattore per il legame degli anticorpi aCL ai fosfolipidi a carica negativa è evidenziata dall' osservazione che gli anticorpi aCL purificati per affinità sono capaci di legarsi ai fosfolipidi anionici contenuti nei liposomi o adsorbiti sulle piastre ELISA solo in presenza di plasma (o siero) umano (o bovino). Il cofattore degli anticorpi aCL è stato isolato e caratterizzato come una proteina a singola catena, con peso molecolare di $50 \mathrm{kD}$ (in condizioni non ridotte), che sale a $70 \mathrm{kD}$ dopo 
riduzione; ha una concentrazione plasmatica di circa $4 \mu \mathrm{mol} / \mathrm{l}(0,2 \mathrm{mg} / \mathrm{ml})$; è stabile al calore (la sua attività cofattore non è alterata dopo $10 \mathrm{~min}$ a $90^{\circ} \mathrm{C}$ ) e può legarsi ai fosfolipidi anionici anche in assenza degli anticorpi aCL. La proteina è stata identificata come $B_{2}$-Glicoproteina I ( $B_{2}$-GPI, anche nota come apolipoproteina $\mathrm{H}$ ). A causa della sua interazione con le superfici a carica netta negativa, la $B_{2}$-GPI possiede numerose proprietà anticoagulanti "in vitro", tra cui c' è la capacità di inibire la conversione della protrombina da parte del complesso protrombinasico (costituito dai fattori della coagulazione $\mathrm{Xa}$ e $\mathrm{Va}$ in presenza di vescicole di fosfatidilserina/fosfatidilcolina, PS/PC). L' inibizione massimale si ottiene a concentrazioni fisiologiche di $B_{2}$-GPI e richiede incubazioni prolungate (circa $60 \mathrm{~min}$ ) con la superficie fosfolipidica.

Gli anticorpi aCL purificati per affinità esprimono due diversi comportamenti nei tests della coagulazione: gli aCL-tipo A prolungano i tests fosfolipide-dipendenti in plasma di origine sia umana, sia animale, mentre gli aCL-tipo $B$ non possiedono attività anticoagulante. L' effetto inibitorio degli aCL-tipo A dipende strettamente dalla presenza della $B_{2}$-GPI: è, infatti, abolito nel plasma depleto di $B_{2}$-GPI ed è nuovamente evidente in seguito al ripristino dell' originale concentrazione plasmatica della proteina. Il meccanismo anticoagulante degli aCL-tipo A è dovuto al potenziamento dell' effetto inibitorio esercitato dalla $B_{2}$-GPI sulla conversione della protrombina da parte del complesso protrombinasico ( $85 \%$ di inibizione entro $10 \mathrm{~min}$ ).

$\mathrm{E}^{\prime}$ importante sottolineare che soltanto una minoranza (circa 1/3) degli anticorpi aCL esprimono attività anticoagulante. Negli altri casi l' effetto inibitorio che si osserva nel plasma contenente anticorpi antifosfolipidi è dovuto alla presenza degli anticorpi LA.

Il complesso protrombinalfosfolipide: cofaltore degli anticorpi $L A$

Gli anticorpi LA isolati e separati dagli aCL non si legano direttamente ai fosfolipidi anionici nei tests immunoenzimatici e non vengono adsorbiti in seguito ad incubazione del plasma con liposomi contenenti cardiolipina. Inoltre, la maggior parte degli anticorpi LA è in grado di inibire i tests della 
coagulazione fosfolipide-dipendenti (quali l' aPTT, il KCT e il dRVVT) in presenza di plasma umano ma non di quello di origine animale. $L$ ' inibizione del dRVVT indica anche che gli anticorpi LA esprimono il loro effetto anticoagulante a livello della conversione della protrombina da parte del complesso protrombinasico. In un sistema contenente fattori purificati della coagulazione (Xa, Va e protrombina) di origine umana e bovina gli anticorpi LA non sono in grado di inibire la conversione della protrombina bovina. L' effetto inibitorio osservato in presenza di protrombina umana è indipendente dall' origine dei fattori $\mathrm{Xa}$ e Va e si esprime solo in presenza di vescicole di PS/PC. Inoltre, gli anticorpi LA si legano ai fosfolipidi anionici solo se quest' ultimi sono preincubati con la protrombina e gli ioni calcio. Perciò, è assai probabile che gli anticorpi LA riconoscano un epitopo esposto in seguito al legame della protrombina umana ai fosfolipidi anionici. Questa speciespecificità non è, però, assoluta, poichè è stata isolata e caratterizzata anche una preparazione di anticorpi LA che riconoscono il complesso fosfolipide anionico/protrombina di origine sia umana, sia animale.

Anticorpi antifosfolipidi: interazione con le piastrine e le microvescicole piastriniche

La membrana delle piastriniche è considerata rappresentare la superficie che catalizza "in vivo" la formazione del complesso attivatore della protrombina (e del fattore X). Tuttavia, i fosfolipdi anionici essenziali per l' espressione delle proprietà procoagulanti delle piastrine sono localizzati principalmente nella superficie intema della membrana e non sono, perciò, disponibili per i processi di coagulazione. Questa distribuzione asimmetrica dei fosfolipidi viene meno in seguito all' attivazione piastrinica, cui conseguono la formazione di una superficie procoagulante e lo "shedding" di microvescicole piastriniche, anch' esse dotate di proprietà procoagulante. I nostri studi sull' effetto degli anticorpi LA e aCL sull' attività procoagulante delle piastrine e delle microvescicole sono stati condotti in presenza e in assenza di $B_{2}$-GPI, usando fattori purificati della coagulazione di origine 
umana e bovina. In presenza dei rispettivi cofattori gli anticorpi LA e aCLtipo A, ma non tipo $B$, interagiscono con la membrana delle piastrine attivate $\mathrm{e}$ delle microvescicole di derivazione piastrinica in maniera sovrapponibile a quanto già osservato con le vescicole di PS/PC. In particolare, l' inibizione dell' attività procoagulante è risultata proporzionale alla quantità di fosfolipide anionico (PS) esposto sulla superficie procoagulante.

In conclusione, abbiamo dimostrato che l' interazione tra gli anticorpi antifosfolipidi e i fosfolipidi anionici è mediata da proteine plasmatiche e che esistono almeno 3 tipi di anticorpi (LA, aCL-tipo A e tipo B), che possiedono diverse proprietà immunologiche ed anticoagulanti. Alla luce di queste nuove osservazioni diventa importante rivalutare il ruolo che questi anticorpi potrebbero svolgere nella patogenesi delle trombosi nell' ambito della sindrome da anticorpi antifosfolipidi. 


\section{HOOFDSTUK VII}

\section{SAMENVATTING EN CONCLUSIES}

Antifosfolipiden antilichamen vertegenwoordigen een grote groep van antistoffen waaronder anticardiolipine (aCL) en lupus anticoagulant (LA). $\mathrm{aCL}$ antilichamen binden aan negatief-geladen lipiden in immunoassays (ELISA), terwijl LA antilichamen de stoltijd van lipid-afhankelijke stoltesten verlengen. Beide antistoffen zijn geassocieerd met een verhoogd risiko voor arteriele en/of veneuze tromboembolische complicaties, spontane abortus en trombocytopenie. Het ziektebeeld dat door aanwezigheid van deze antistoffen wordt gekarakteriseerd, wordt aangeduid als het "Antifosfolipiden syndroom". Omdat aCL en LA antilichamen gemeenschappelijk voorkomen in $75 \%$ van de gevallen en omdat sommige affiniteits-gezuiverde aCL antilichamen lipidafhankelijke stolreakties remmen, zijn deze beide antilichamen lange tijd als identiek beschouwd. In de afgelopen jaren echter, is aangetoond dat in de meerderheid van de gevallen aCL antilichamen kunnen worden gescheiden van LA antilichamen. Bovendien werd duidelijk dat de interaktie tussen antifosfolipid antilichamen en hun veronderstelde antigenen aanzienlijk complexer is dan voorheen werd aangenomen en dat deze interaktie via eiwit "cofactoren" plaatsvindt.

$\beta_{2}$-Glycoprotein I: cofactor voor de binding van aCL antilichamen

Aanwijzing voor de noodzaak van een cofactor voor de binding van $\mathrm{aCL}$ antistoffen aan negatief-geladen fosfolipiden kwam door de observatie dat geïsoleerde aCL antilichamen uitsluitend in aanwezigheid van humaan (of runder) plasma (of serum) in staat waren te binden aan liposomen bestaande uit negatief-geladen lipid of aan ELISA platen gecoat met deze lipiden. Deze "aCL-cofactor" werd gezuiverd en gekarakteriseerd als een enkelvoudige 
polypeptideketen met een schijnbare molecuulmassa van $50 \mathrm{kD}$ (nietgereduceerd), toenemend tot $70 \mathrm{kD}$ na reduktie; de concentratie van dit eiwit in plasma bedraagt ongeveer $4 \mu \mathrm{mol} / \mathrm{l}(0,2 \mathrm{mg} / \mathrm{ml})$; het eiwit is hittestabiel (10 minuten verhitting op $90{ }^{\circ} \mathrm{C}$ geeft geen afname in cofactor aktiviteit) en bindt aan anionische fosfolipiden, ook in afwezigheid van aCL antilichamen. Het eiwit werd geïdentificeerd als $B_{2}$-glycoprotein I ( $B_{2}$-GPI, ook wel aangeduid als apolipoprotein $\mathrm{H}$ ). Aangetoond werd dat ten gevolge van zijn interaktie met negatief-geladen oppervlakken, $B_{2}$-GPI "in vitro" verschillende anticoagulante eigenschappen vertoont, waaronder het vermogen de aktivering van prothrombine door het enzymcomplex factor $\mathrm{Xa}-\mathrm{Va}$ in aanwezigheid van fosfatidylserine/fosfatidylcholine (PS/PC) vesicles te remmen. Deze remming is maximaal bij fysiologische concentraties van het eiwit en vereist langdurige incubatie met het fosfolipiden oppervlak (ongeveer 60 minuten zijn nodig voor maximale expressie van de remming).

Op grond van hun gedrag in stoltesten kunnen aCL antilichamen worden ingedeeld in twee verschillende groepen: aCL-type A antilichamen verlengen de stoltijd van lipid-afhankelijke stolreakties in plasma van zowel humane als dierlijke oorsprong, terwijl aCL-type B antilichamen geen anticoagulante werking vertonen. De remmende werking van aCL-type $A$ is strikt afhankelijk van de aanwezigheid van $B_{2}$-GPI, hetgeen blijkt uit het feit dat de verlengde stoltijden normalizeren bij verwijdering van $B_{2}$-GPI uit het plasma; toevoegen van $B_{2}$-GPI-deficient plasma geeft weer aanleiding tot verlenging van de stoltijden door dit type antilichamen. De anticoagulante eigenschappen van aCL-type $A$ worden verklaard door potentiering van de $B_{2}$-GPI remming op de omzetting van prothrombine door het complex van de factoren $\mathrm{Xa}$ en Va op $\mathrm{PS} / \mathrm{PC}$ vesicles ( $85 \%$ remming in 10 minuten). Het is van belang te onderstrepen dat van de aCL preparaten slechts een gering deel (ongeveer 1/3) dexe anticoagulante eigenschappen vertoont. In de andere gevallen wordt de anticoagulante aktiviteit van het plasma verklaard door aanwezigheid van LA antilichamen. 
Lipid-gebonden prothrombine: cofactor voor de binding van LA antilichamen

Geïsoleerde LA antilichamen, gescheiden van aCL antilichamen, binden niet rechtstreeks aan anionische fosfolipiden in de ELISA, noch kunnen deze antistoffen uit het plasma worden verwijderd door middel van adsorptie aan cardiolipine-bevattende liposomen. Bovendien blijken de meeste LA antilichamen uitsluitend in humaan plasma een verlenging te veroorzaken van de stoltijden van lipid-afhankelijke stoltesten (zoals bijvoorbeeld aPTT, KCT en dRVVT); toegevoegd aan runder-, schape-, of ratte-plasma vertonen deze gezuiverde LA antistoffen geen anticoagulante werking. Verlenging van de dRVVT wijst er op dat LA antistoffen werkzaam zijn op het niveau van de omzetting van prothrombine naar thrombine door factoren $\mathrm{Xa} / \mathrm{Va}$ op een lipiden oppervlak. In een meetsysteem gebruik makend van zuivere stolfactoren ( $\mathrm{Xa}, \mathrm{Va}$ en prothrombine) van humane of runder oorsprong wordt, noch in aan- noch in afwezigheid van PS/PC vesicles, een significante remming waargenomen op de omzettingssnelheid van runder-prothrombine. Remming wordt uitsluitend waargenomen op de omzettingssnelheid van humaan prothrombine en is onafankelijk van de oorsprong van de factoren $\mathrm{Xa}$ en Va. Bovendien wordt de remming niet waargenomen in afwezigheid van lipid. Tevens kon worden aangetoond dat LA antilichamen alleen in aanwezigheid van humaan prothrombine en calcium-ionen aan anionische fosfolipiden kunnen binden. Het meest waarschijnlijke is daarom dat deze LA antilichamen een epitoop herkennen dat geëxposeerd wordt als gevolg van de calcium-gemedieerde binding van humaan prothrombine aan negatief-geladen fosfolipiden oppervlakken. Deze soort-specificiteit lijkt evenwel niet absoluut te zijn; tenmiste één LA antilichaam preparaat bleek lipid-gebonden prothrombine te herkennen van zowel mens als rund.

Antifosfolipiden antilichamen: interaktie met bloedplaatjes en daarvan afgeleide microvesicles:

Het katalytisch oppervlak voor de vorming van het prothrombine- 
aktiverende complex (en ook het faktor X-aktiverende complex) "in vivo" wordt naar alle waarschijnlijkheid geleverd door de fosfolipiden in het plasmamembraan van de bloedplaatjes. De voor de katalytische eigenschappen van het oppervlak verantwoordelijke lipiden bevinden zich in het niet geaktiveerde bloedplaatje echter aan de cytoplasmatische zijde van de plasmamembraan. Afhankelijk van de agonist leidt aktivatie van bloedplaatjes tot een verlies van deze asymmetrische fosfolipidenverdeling, hetgeen resulteert in de vorming van een procoagulant fosfolipidenoppervlak en tevens het afsnoeren van procoagulante microvesicles. Onze studies betreffende de effecten van LA en aCL-type A en B antilichamen op de procoagulante aktiviteit van geaktiveerde plaatjes en microvesicles werden uitgevoerd in aanen afwezigheid van $B_{2}$-GPI, opnieuw gebruikmakend van gezuiverde stollingsfactoren van humane- en runder oorsprong. In aanwezigheid van hun respectivelijke cofactoren blijken LA en aCL-type A de procoagulante aktiviteit van geaktiveerde plaatjes en plaatjesmicrovesicles op een soortgelijke manier te remmen als hierboven beschreven voor PS/PC vesicles, terwijl de aCL-type B antilichamen ook hier geen anticoagulante werking vertoonden. De mate van remming van procoagulant aktiviteit is evenredig met de hoeveelheid anionisch fosfolipid (PS) geëxposeerd aan het celoppervlak.

Concluderend kan gesteld worden dat de interaktie tussen antifosfolipiden antilichamen en anionische fosfolipiden wordt gemedieerd door plasma eiwitten en dat er tenmiste drie verschillende typen antilichamen (LA, aCL-type A en B) kunnen worden onderscheiden, met elk verschillende immunologische en anticoagulante eigenschappen. In het licht van deze bevindingen zal een re-evaluatie noodzakelijk zijn van de rol van antifosfolipiden antilichamen in de pathogenese van tromboembolische complicaties, die zo veelvuldig voorkomen bij patienten met het antifosfolipiden syndroom. 


\section{LIST OF PUBLICATIONS}

1. Finazzi G, Cortelazzo S, Viero P, Galli M, Barbui T. Maternal lupus anticoagulant and fatal neonatal thrombosis. Thromb Haemostas 1987, 57: 238

2. Barbui T, Cortelazzo S, Galli M, Finazzi G. L'anticoagulante tipo lupus. Haematologica 1987; 72 (Suppl): 213-221

3. Finazzi G, Galli M, Viero P, Defanti CA, Tiraboschi L, Barbui T. Association between lupus anticoagulant and epilepsy. La Ricerca Clin Lab 1987; 17: 35-39

4. Barbui T, Cortelazzo S, Galli M, Parazzini F, Radici E, Rossi E, Finazzi G. Anti-phospholipid antibodies in early repeated abortions: a case-control study. Fertility and Sterility 1988; 50: 589-592

5. Galli M, Cortelazzo S, Viero P, Finazzi G, de Gaetano G, Barbui T Interaction between platelets and lupus anticoagulant. Eur J Haematol 1988; 41: $88-94$

6. Gaili M, Béguin S, Lindhout T, Hemker HC. Inhibition of platelet and phospholipid-dependent prothombinase activity in the plasma of patients with Lupus Anticoagulants. Br J Haematol 1989; 72: 549-55

7. Finazzi G, Cortelazzo S, Galli M, Barbui T. Relative risk of recurrent abortion and thrombosis in young subjects with antiphospholipid antibodies estimated by case-control studies. Postgraduate Med J 1989; 65: 697

8. Galli M, Cortelazzo S, Barbui T. Lack of cross-reactivity between anticardiolipin antibodies and glycosaminoglycans. Thromb Res 1990; 69: 363-67

9. Galli M, Finazzi G, Barbui T. Importanza clinica della determinazione degli anticorpi antifosfolipidi. Progressi in Medicina di Laboratorio 1990; 4: 501-05

10. Galli M, Comfurius P, Maassen C, Hemker HC, de Baets MH, van Breda-Vriesman PJC, Zwaal RFA, Bevers EM. Anticardiolipin antibodies (ACA) directed not to cardiolipin but to a plasma protein cofactor. Lancet 1990; 335: $1544-47$

11. Bevers EM, Galli M. $B_{2}$-glycoprotein I for binding of anticardiolipin antibodies to cardiolipin. Lancet 1990; 336: 952-53

12. Galli M, Barbui T, Bevers EM, Comfurius P, Zwaal RFA, The plasma cofactor and anticardiolipin antibodies: authors' reply. Clin Exp Rheum 1990; 


\section{8: $614-15$}

13. Bevers EM, Galli M, Barbui T, Comfurius P, Zwaal RFA. Lupus anticoagulant IgG's (LA) are not directed to phospholipids only, but to a complex of lipid-bound human prothrombin. Thromb Haemostas 1991; 66: 629-32

14. Galli M, Cortelazzo S, Barbui T. In vivo efficacy of intravenous gammaglobulins in patients with lupus anticoagulant is not mediated by an anti-idiotypic mechanism. Am J Haematol 1991; 38: 184-88

15. Finazzi G, Galli M, Barbui T. L'anticoagulante tipo-lupus e gli anticorpi anticardiolipina. La trasfusione del sangue 1991; 36: 97-102

16. Galli M, Cortelazzo S, Daldossi M, Barbui T. Increased levels of $B_{2}$ glycoprotein I (aca-cofactor) in patients with lupus anticoagulant. Thromb Haemostas 1992; 67: 386

17. Bevers EM, Galli M. Cofactors involved in the antiphospholipid syndrome. Lupus 1992; 1: 51-53

18. Galli M, Comfurius P, Barbui T, Zwaal RFA, Bevers EM. Anticoagulant activity of $B_{2}$-glycoprotein $I$ is potentiated by a distinct subgroup of anticardiolipin antibodies. Thromb Haemostas 1992; 68: 297-300

19. Galli M, Bevers EM, Comfurius P, Barbui T, Zwaal RFA. Effect of antiphospholipid antibodies on procoagulant activity of activated platelets and platelet-derived microvesicles. Br J Haematol (in press)

20. Naldi L, Locati F, Marchesi L, Cortelazzo S, Finazzi G, Galli M, Brevi A, Cainelli T, Barbui T. Cutaneous manifestations associated with antiphospholipid antibodies in patients without systemic lupus erythematosus: a case-control study. Ann Rheum Dis (in press)

21. Galli M, Barbui T, Zwaal RFA, Comfurius P, Bevers EM. "Antiphospholipid antibodies": involvement of protein cofactors. Haematologica (in press) 


\section{AKNOWLEDGEMENTS}

The work presented in this thesis would not have been possible without the precious help of the people in Italy and in The Netherlands, who supported me during these years of experiments. Here I have the opportunity to thank them:

in the first place my aknowledgements are addressed to prof. T. Barbui, with whom I have been fruitfully working since 1984 . He first introduced me to the fascinating world of research in the field of haemostasis and thrombosis and he has been the primum movens of this adventure in The Netherlands. In this respect, prof. G. de Gaetano shares his part of responsabilities: I will always be grateful to him not only for the many scientific discussions, but also for the suggestion of the Department of Biochemistry of the Rijksuniversiteit Limburg as the laboratory where to perform my studies on antiphospholipid antibodies and for helping me to receive a European Community grant. My gratitude extend also to prof. N. Semeraro, to prof. M.B. Donati and to all the people of the "M. Negri" Institute.

I wish to thank all my collegues at the Department of Haematology of Bergamo and also the "Direzione Sanitaria" of the Ospedali Riuniti of Bergamo. Without their support and understanding, my leave of absence from the department would not have been possible. I particularly want to thank $\mathrm{dr}$. Sergio Cortelazzo, for being not only a patient tutor, but also a good friend.

To prof. H.C. Hemker goes my gratitude for accepting me in his laboratory and for guiding me during my first months in The Netherlands. Dr. S. Béguin and dr. T. Lindhout, thank you for your help and kindness.

I am deeply in debt with "de jongens van het lab", with whom this work has been made: my co-promotor, Edouard Bevers, my promotor, Rob Zwaal, and Paul Comfurius.

Edouard, without your help and encouragement, especially during the long months in which nothing seemed to work out, I would surely not been able to accomplish the experiments of this thesis. Besides, by offering me your warm friendship, you helped me to feel home in a foreign and cold country and by opening your house to me, you let me feel part of your family. Rob, your 
volcanic mind has been an inexhaustible mine of ideas and suggestions, often crucial for the progress of the work (anyway, isn't this why the professor is for?...). Paul, your help and suggestions have smoothed and eased the daily problems. Thinking of the lab as a special kitchen, you are undoubtely "le gran chef".

I wish to thank also all the other "jongens en meisjes van het lab" who helped me during the long pipetting hours. In particular, Cecile and Johan, thank you for your enthusiasm and kindness.

I am grateful to Jan Rosing, Guido Tans, Kees Vermeer and Ritje van DamMieras for the helpful discussions, to Harry Andree and Marc Stuart for performing the experiments with the ellipsometer and the electron microscope, respectively. I am in debt with dr. M. de Baets and prof. P. van Breda Vriesman for the fruitful suggestions and for allowing me to use some facilities of the Department of Immunology. In this respect, I will never be able to repay Berry, Birgit, Truus, Rob W. and Hans for the reagents, purified coagulation factors, tools (did I forget anything?....) I have "borrowed" during these years.

Mariet and Trees, your kindness and friendship I will always remember.

Finally, I want to thank in a special way Paul, Puck and Reneé. You have both helped me to overcome the many problems that a foreigner encounter in The Netherlands and offered me your warm friendship, which has been and will always be a precious gift to me.

To everyone who has helped me during these years, thanks

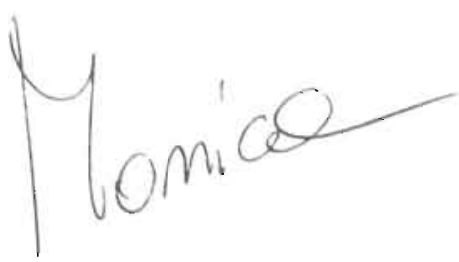




\section{CURRICULUM VITAE}

The writer of this thesis was born on July 10th 1960 in Darfo (Italy). In 1979 she finished high school at the "Liceo Scientifico" of Alzano Lombardo. In 1985 she accomplished her studies in medicine at the University of Milano. From 1985 to 1988 she attended the school of specialization in clinical and laboratory haematology at the University of Parma.

Since december 1989 she has been working as assistent professor (specialist in haematology) at the Department of Haematology of the Ospedali Riuniti of Bergamo (IItaly).

From june 1987 to march 1989 she was recipient of a grant of the European Community and she worked at the Department of Biochemistry of the Rijksuniversiteit Limburg, Maastricht, The Netherlands. In 1991 she was admitted to the preparation of a Ph.D. degree in The Netherlands by the dutch. Ministery of Education. From october to december 1989, 1990 and 1991 she has been on leave of absence from the Department of Haematology of the Ospedali Riuniti of Bergamo and working again at the Department of Biochemistry of the Rijksuniversiteit Limburg. During these periods of time the main part of the present thesis has been prepared under the leadership of. prof. R.F.A. Zwaal and dr. E.M. Bevers. 
Tipolitografia Grafital s.n.c. - Torre: Boldone (Bg) 
